\title{
27. SEDIMENTS FROM THE GULF OF ADEN AND WESTERN INDIAN OCEAN
}

\author{
D. S. Cronan, Department of Geology, Imperial College, London, S. W. 7, U.K. \\ V. V. Damiani, Canada Centre for Inland Waters, Burlington, Ontario, Canada \\ D. J. J. Kinsman, Department of Geological and Geophysical Sciences, Princeton University, Princeton, New Jersey \\ and \\ J. Thiede, Geologisk Institutt, Universitetet i Bergen, Norway ${ }^{1}$
}

\section{TABLE OF CONTENTS}

Introduction

Site Summaries

Sedimentary Components
(a) Biogenic
(b) Terrigenous
(c) Volcanogenic
(d) Authigenic

1047

1047

1051

1051

1051

1058

1061

\section{INTRODUCTION}

During Leg 24 three drilling sites were occupied in the Gulf of Aden $(231,232,233)$, two in the Somali Basin $(234,235)$, and three in the western Indian Ocean (236, $237,238)$. The location of these sites is shown in Figure 1; latitude, water depth, and penetration depth are indicated in Table 1. Figure 2 summarizes the lithologies and stratigraphy of all eight sites cored.

In this chapter are included lithologic summaries for each of the sites. The sediments are then discussed in terms of their individual biogenic, terrigenous, volcanogenic, or authigenic components and their sedimentary structures. In a series of synthesis sections the hemipelagic, pelagic, and basal metaliferous sedimentary facies are discussed.

\section{SITE SUMMARIES}

\section{Site 231}

Site 231, in the Gulf of Aden, lying $80 \mathrm{~km}$ north of the Somali coastline, was penetrated to a depth of 584.0 meters, the lowermost 17.5 meters of which was basalt underlying Miocene sediments. From 0 to 64 meters the sediment consists of light olive-gray nanno ooze containing intercalated sandy horizons with reef debris. From 64 to 121 meters the sediment is a fairly uniform nannofossil ooze, containing some shallow-water fossils indicative of slumping. The Pliocene/Pleistocene boundary is at 102 meters. Below 121 meters to a depth of 236 meters, nanno oozes contain more layers of coarse sediments, including four volcanic ash layers. The lowermost Pliocene, and, below 254 meters, the Miocene deposits are lithologically similar, and consist of a uniform grayish-olive nanno ooze. There are occasional patches of bitumen and one shelly quartzose sand layer. $\mathrm{H}_{2} \mathrm{~S}$ was common in this part of the

\footnotetext{
${ }^{1}$ Present address: Department of Oceanography, Oregon State University, Corvallis, Oregon.
}

Sedimentary Structures $\quad 1065$

Sedimentary Facies $\quad 1068$

(a) Hemipelagic 1068

(b) Pelagic 1069

(c) Basal Metalliferous 1070

Appendix: Smear Slide Graphic Summaries $\quad 1086$

section, indicating reducing conditions. Nanno chalk layers of Middle Miocene age are intercalated within the basalt below 566.5 meters. Sedimentation rates are thought to be approximately $51 \mathrm{~m} / \mathrm{m} . \mathrm{y}$. in the Pliocene and Pleistocene and about $38 \mathrm{~m} / \mathrm{m} . y$. in late Miocene. However, these differences could reflect the increasing compaction and consolidation of the sediment with age.

\section{Site 232}

Site 232 is located at the lip of the western flank of the Alula-Fartak Trench, a north-northeast, south-southwesttrending feature at the eastern entrance to the Gulf of Aden. Coring was completed to 434 meters and within this section six lithologic units were distinguished. Unit 1 ranges in age from late Miocene to Recent whereas Units 2 to 6 are all late Miocene in age. Units 1, 4, and 6 comprised a rather monotonous sequence of olive-gray to dusky yellow-green nanno oozes with occasional thin quartzose sand layers, some of which are pyritiferous. Two acid volcanic ash layers occur at 164 and 165 meters. The general uniformity of this lithologic unit suggests rather constant conditions of water depth, pelagic carbonate production, and detrital sediment input to have held sway since the late Miocene. Lithologic Units 2, 3 , and 5 are well-lithified, calcite-cemented, quartz siltstones and sandstone, and seem exotic in this otherwise rather typical hemipelagic section. An origin as fault or slide blocks derived from a shallower-water, near-shore environment to the north or northwest is suggested for these rocks. Alternatively, the clastic grains themselves may have slumped unlithified into this location, and later calcite cementation has ensued because the high porosity of the sediments has allowed ready passage of carbonate precipitating pore waters through them. Average sedimentation rate during the Recent/Pleistocene/Pliocene was $55 \mathrm{~m} / \mathrm{m}$.y. and for the upper part of the late Miocene approximately $89 \mathrm{~m} / \mathrm{m} . \mathrm{y}$. The higher sedimentation rate for the lower lithologic units may be caused by slumping. 


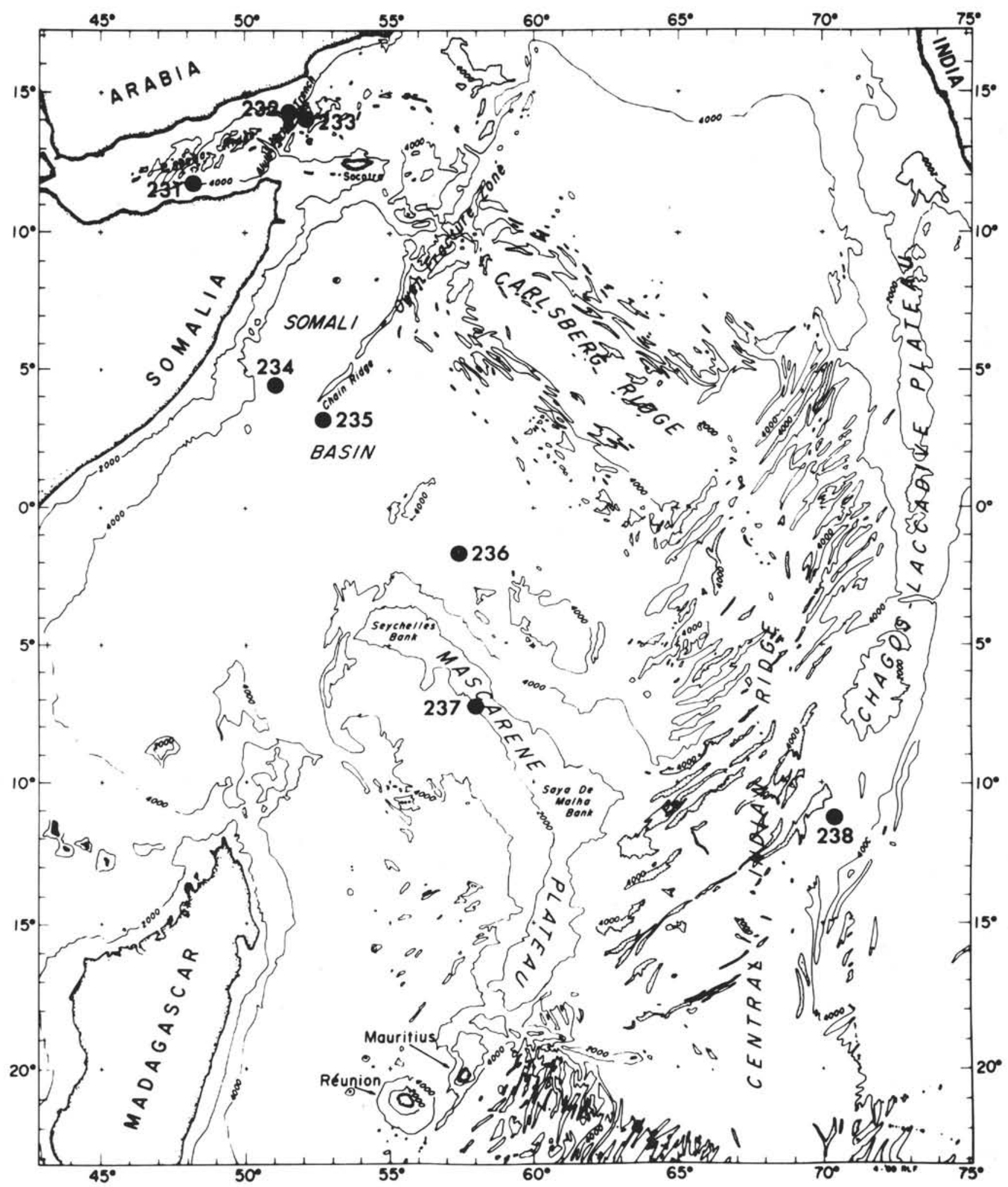

Figure 1. Location of Leg 24 Sites. 
TABLE 1

Location of Leg 24 Sites

\begin{tabular}{lcccc}
\hline & Longitude & $\begin{array}{c}\text { Water } \\
\text { Depth } \\
(\mathrm{m})\end{array}$ & $\begin{array}{c}\text { Penetration } \\
(\mathrm{m})\end{array}$ \\
\hline Hole & Latitude & L & & 584 \\
231 & $11^{\circ} 53.41^{\prime} \mathrm{N}$ & $48^{\circ} 14.71^{\prime} \mathrm{E}$ & 2161 & 434 \\
$232 \mathrm{~A}$ & $14^{\circ} 28.93^{\prime} \mathrm{N}$ & $51^{\circ} 54.87^{\prime} \mathrm{E}$ & 1758 & \\
233, & $14^{\circ} 19.68^{\prime} \mathrm{N}$ & $52^{\circ} 08.11^{\prime} \mathrm{E}$ & 1860 & 271 \\
$233 \mathrm{~A}$ & & & & \\
234, & $04^{\circ} 28.96^{\prime} \mathrm{N}$ & $51^{\circ} 13.48^{\prime} \mathrm{E}$ & 4738 & 247 \\
$234 \mathrm{~A}$ & & & & \\
235 & $03^{\circ} 14.06^{\prime} \mathrm{N}$ & $52^{\circ} 41.64^{\prime} \mathrm{E}$ & 5146 & 684 \\
236 & $01^{\circ} 40.62^{\prime} \mathrm{S}$ & $57^{\circ} 38.85^{\prime} \mathrm{E}$ & 4504 & 328 \\
237 & $07^{\circ} 04.99^{\prime} \mathrm{S}$ & $58^{\circ} 07.48^{\prime} \mathrm{E}$ & 1640 & 694 \\
238 & $11^{\circ} 09.21^{\prime} \mathrm{S}$ & $70^{\circ} 31.56^{\prime} \mathrm{E}$ & 2844 & 587 \\
\hline
\end{tabular}

\section{Site 233}

Site 233 was drilled in almost 1860 meters of water on the back side of the eastern flank of the Alula-Fartak Trench, about $30 \mathrm{~km}$ southeast of Site 232. A 235-meter section of nanno ooze ranging in age from late Pliocene to Recent was found to overlie a diabase sill. The lowermost 5 meters of the sediment section is fairly hard, suggestive of baking by the intrusive. One acid volcanic ash layer and one quartzose sand layer occur within the sequence. Sedimentation rates were determined to be $45 \mathrm{~m} / \mathrm{m}$.y. for the Pleistocene/Recent and $94-117 \mathrm{~m} / \mathrm{m} . \mathrm{y}$. for the late Pliocene.

\section{Site 234}

Site 234 was drilled in 4740 meters of water in the westernmost part of the northwest Somali Basin. Penetration to 247 meters revealed a sedimentary section of late Oligocene to Recent age comprising gray to green nanno clay and clays. The bulk of the sediments comprises clay minerals, together with badly preserved biogenic components and minor volcanic and terrigenous components. Sedimentation conditions seem to have been oxidizing after the middle Miocene and rather more reducing during the Oligocene to middle Miocene. The badly preserved calcareous nannofossils suggest that the site was close to the carbonate compensation depth (CCD) throughout the time of deposition. Volcanic input seems to have been an important sediment source at this site and may be the origin of most of the clays found at this site. Sedimentation rates are about $1 \mathrm{~m} / \mathrm{m}$.y. for the post middle Miocene section, $13 \mathrm{~m} / \mathrm{m} . \mathrm{y}$. for the early and middle Miocene sections, and $7 \mathrm{~m} / \mathrm{m}$.y. for the late Oligocene.

\section{Site 235}

Site 235 was drilled in 5146 meters of water, and a 684 meter sediment section was penetrated. The site is located at the westernmost edge of the abyssal plain that onlaps the eastern flank of Chain Ridge. Intermittent coring recovered a sequence of nanno oozes, nanno clays, and clays overlying basalt. Occasional sand layers and volcanic glass layers were encountered, but the sediments are dominated by clay minerals. Sedimentation rates for the entire section from Recent to middle Miocene average 37 $\mathrm{m} / \mathrm{m} . \mathrm{y}$. Sedimentary inclusions within the basement basalts were determined to be of Maestrichtian age. Fluctuations in the CCD seem to have occurred, and the sedimentary environment has changed from oxidizing to more reducing with time. The minor turbidite units may possibly have come from Chain Ridge or the slopes above the northern margin of the abyssal plain. The clay minerals may have a volcanic source, as suggested for Site 234.

\section{Site 236}

Site 236 is situated about $270 \mathrm{~km}$ northeast of the Seychelles Island block and was planned to date an ancient magnetic anomaly pattern associated with the Carlsberg Ridge. Penetration to 327.5 meters was achieved, a 306-meter sediment section overlying basaltic basement. The sediments can be divided into six lithologic units comprising mainly light-colored biogenic oozes and chalks (radiolarian ooze, foram ooze, nanno ooze, nanno chalk). Units 2, 3, and 6 contain, in addition to the biogenic components, thin clay layers with a high content of clay minerals; the sediment of these units is ferruginous and has a brownish hue. The clays contain up to $5 \%$ zeolites. Stratigraphically, this section comprises deposits of Paleocene to Quaternary age. Average sedimentation rates increase from about $3.3 \mathrm{~m} / \mathrm{m} . \mathrm{y}$. during the late Paleocene to early Miocene to $11.3 \mathrm{~m} / \mathrm{m} . \mathrm{y}$. for the middle Miocene to Recent. The bulk of the sediments is biogenic in origin, indicative of an open-oceanic depositional environment. Terrigenous matter is represented by small amounts of clay minerals and traces of other detrital minerals.

\section{Site 237}

Site 237 was drilled in 1630 meters of water in the saddle joining the Seychelles Bank to Saya de Malha. A 694-meter sediment section was penetrated and comprised primarily nanno oozes with subordinate chert and glauconite. The lower 273 meters is considerably altered and recrystallized. Pelagic sediments dominate the entire 

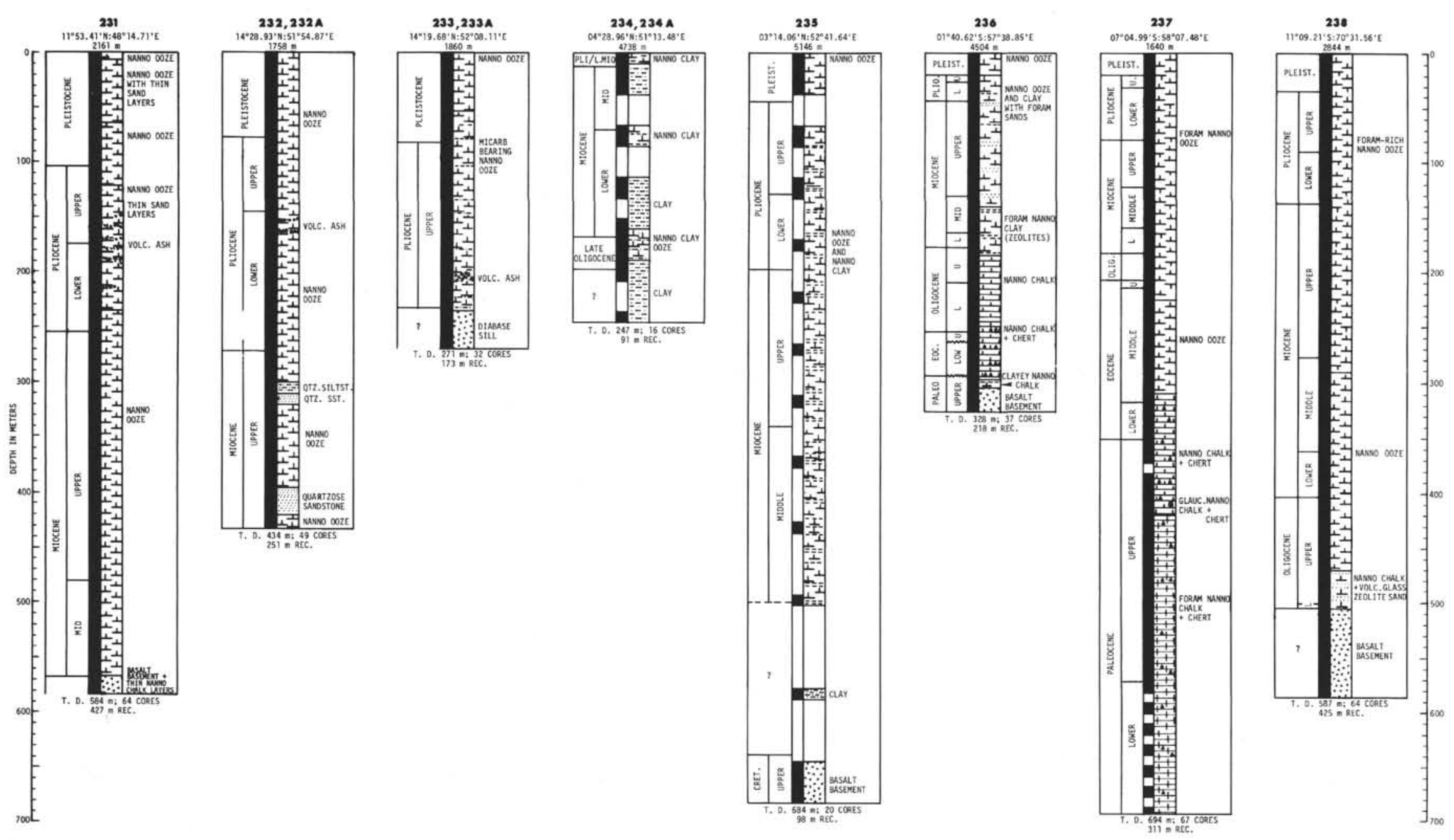

Figure 2. Lithologic and stratigraphic summary of Leg 24 sites. 
section, although evidence is found in the lower portions suggestive of relatively shallower water (presence of glauconite, lensing and lamination, and reef debris). The data suggest the site has subsided possibly $2 \mathrm{~km}$ in 60 m.y. Sedimentation rates for the post middle Miocene section average $11.3 \mathrm{~m} / \mathrm{m} . \mathrm{y}$.; for the Oligocene and early Miocene an average rate of $2 \mathrm{~m} / \mathrm{m}$.y. was determined. Eocene to lower Paleocene rates are extremely variable ranging from $1.2 \mathrm{~m} / \mathrm{m}$.y. to $60.2 \mathrm{~m} / \mathrm{m}$.y. The high rates for the early Paleocene support the suggestion of extensive early Tertiary slumping of fine-grained and reefal sediments to this site; the slumping developed the extremely thick Paleocene deposits $(\sim 350 \mathrm{~m})$.

\section{Site 238}

Site 238, at the extreme northeast end of the Argo Fracture Zone, was continuously cored to basement at 506 meters, and then a further 80.5 meters into the basalt. Three sedimentary units are present. Down to 471.5 meters, the sediments are nannofossil oozes, two units within this interval being distinguished on the basis of variations in foram and iron ozide content. The upper unit is white to light gray in color and contains streaks of pyrite. The lower unit ranges in color from pale orange at the top to light or moderate brown at the base, the color change being caused by an increasing concentration downward, of iron oxides. The lowermost sedimentary unit is 34.5 meters thick; is multicolored in shades of orange, brown, and green; and contains intercalated horizons of volcanic debris. Amorphous iron oxides are locally abundant in these sediments, possibly indicating hydrothermal activity. No disconformities were encountered within the sedimentary sequence. Sedimentation rates varied from 21 to $45 \mathrm{~m} / \mathrm{m}$.y. (av. $25.9 \mathrm{~m} / \mathrm{m} . \mathrm{y}$.) in post early Miocene, indicating high productivity in the waters overlying the site, and from 5 to $13 \mathrm{~m} / \mathrm{m} . \mathrm{y}$. (av. $8.7 \mathrm{~m} / \mathrm{m} . \mathrm{y}$.) in the early Miocene Oligocene. However, sedimentation rates in the lowermost unit probably varied considerably, dependent on the incidence of submarine volcanism near the site of deposition.

\section{SEDIMENTARY COMPONENTS}

\section{Biogenic Components}

Biogenic components found in Leg 24 sediments can be divided into three categories:

Calcareous: algal crusts, coccoliths, foraminifera (planktonic and benthonic), corals, molluscs, echinoderms

Siliceous: diatoms, silicoflagellates, Radiolaria, sponges

Other components: arenaceous foraminifera, fish debris The distribution of these biogenic components are graphically shown in the Appendix to this chapter. Some of these are illustrated in photomicrographs of thin sections, smear slides, and polished sections (Plates 1-4). Fragments of algal crusts are found in Paleocene cores at Site 237 (Cores 55, 58, 61) along with other shallow-water-derived material.

Coccoliths are abundant at all sites with the exception of Site 234 in the Somali Basin, where only a few horizons contain coccoliths. The marine planktonic algae producing coccoliths are the major source of pelagic deep-sea sediments in the Indian Ocean as well as in other oceans (Berger and von Rad, 1972). Preservation of calcareous nannoplankton is good at most sites. Badly preserved floras were found in the sediments at Site 234 and also in some horizons in the Gulf of Aden sites.

Planktonic foraminifera are the most common coarse constituent of the Indian Ocean sediments, although usually they comprise less than $10 \%$ of the sediments. There are only a few horizons at Site 231 (Pleistocene, Pliocene), at Site 232 (Pleistocene), and at Site 235 (middle Miocene), which contain considerably more foraminifera. However, the sediments at low-latitude sites around the Seychelles are much richer in foraminifera. Sediments deposited here since the upper Paleocene usually contain up to $40 \%$ planktonic foraminifera.

Calcareous benthonic foraminifera are found in very small quantities at all sites, but are present in sizable quantities in the Gulf of Aden sediments and in the lowermost part of Site 237 (Paleocene). In both cases it is assumed that they are displaced from shallower water depths.

Other calcareous biogenic components occur rarely and are treated in more detail in Chapter 12 (this volume).

The main siliceous components usually occur together in small quantities. Radiolaria are more abundant in sediments of the low-latitude sites (Sites 236, 237, 238), but are also found as minor constituents in the sediments of all other sites (Plates 1-4). Radiolarian ooze occurs in the Pleistocene at Site 236.

Sponge spicules are usually found as accessory components in sediments of all sites, but they are concentrated in the Somali Basin sediments due to the solution of calcareous material in this area.

Arenaceous benthonic foraminifera are rare at all sites because they are not normally preserved after deposition.

Fish debris is found throughout the sites in small quantities. Only at Sites 234 and 235 does it make up a greater portion of the coarse fraction. This is due to the dissolution of the otherwise abundant calcareous components; however, the proportion of coarse fraction at these sites is so small that they are quantitatively negligible.

\section{Terrigenous Components}

\section{Introduction}

Poor distribution of terrigenous sediments was observed at all Leg 24 sites. Their occurrence decreases from the northwest (Gulf of Aden), where they comprise 5\%-20\% of the sediment, towards the southeast (Central Indian Ridge), where they practically disappear. The presence of terrigenous sediments is indicated by the occurrence of quartz, by the presence of detrital calcite (Figure 3), or by sand layers and lenses (Figure 4).

Terrigenous sands and coarse silts are particularly abundant throughout the Plio-Pleistocene hemipelagic sequences at Sites 231 and 232 and throughout the Miocene hemipelagic sequence at Site 232 in the Gulf of Aden. Here terrigenous sediments are found as layers or lenses included in a rather uniform nannoplankton-rich hemipelagic ooze, while both the Plio-Pleistocene detrital carbonate (Site 233) and the Miocene quartz (Site 234) are 


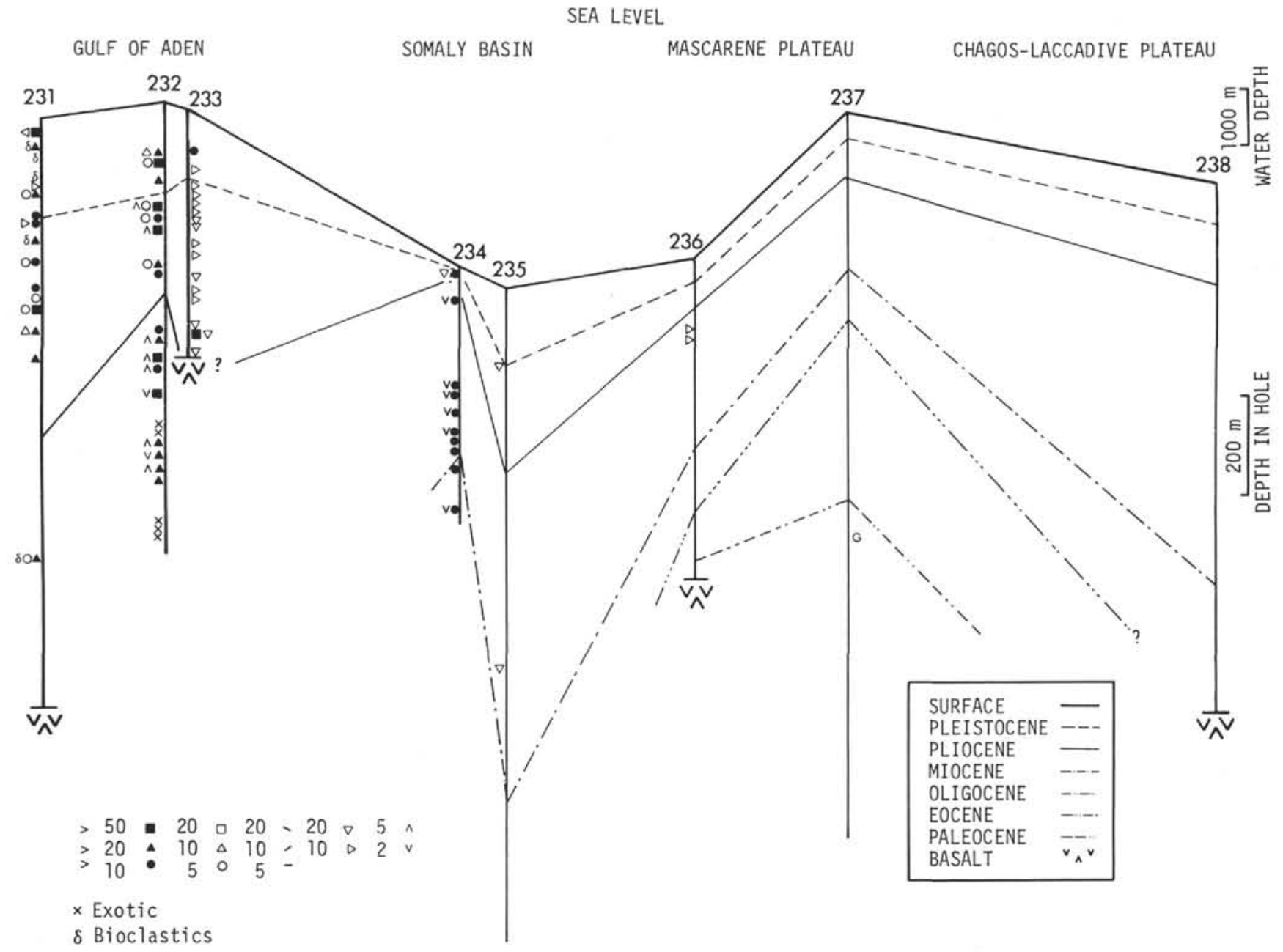

Figure 3. Occurrence of major detrital minerals at Leg 24 sites.

distributed throughout the nannoplankton-rich hemipelagic ooze as scattered grains. Terrigenous sediments are practically absent throughout the east Somali Basin (Site 235), the Mascarene Plateau (Sites 236 and 237), and the Chagos-Laccadive Ridge (Site 238).

Virtually all the terrigenous layers found at Sites 231 and 232 range between feldspar-rich graywackes and normal graywackes, with the exception of the well-lithified siltstone and sandstone found in the Miocene sequence of Hole 232A, which is classified between quartzose sandstone and quartzose arkose. The sedimentary sections at the three sites $(231,232,233)$ in the Gulf of Aden, are surprisingly uniform and composed of nannoplankton-rich hemipelagic ooze. This suggests near-constant conditions of water depth and carbonate productivity in this area with local variations in detrital input.

At Site 231, the Pleistocene and Pliocene vary more in lithology than the section of the same ages at Sites 232 and 233. The sands here change in composition, and some include material of reef origin, possibly resulting from erosion of reefs on the continental shelf during periods of lowered sea level during the upper Pliocene and Pleistocene. Quartz, feldspar, and mica in silt- and sand-sized grains occur as thin layers or scattered grains in the ooze and are common in the Plio-Pleistocene sequences of both Sites 231 and 232. These components are the result of a terrigenous sediment supply from the Arabian Peninsula and the African Continent.

Site 231 sediments are extremely homogeneous hemipelagic nanno ooze with one shelly quartzose sandy layer. At Site 232, fairly abundant sand- and silt-sized detrital grains are dispersed throughout the Miocene hemipelagic ooze. Moreover, well-lithified calcite-cemented quartzose siltstone and sandstone occur toward the bottom of the section. These sediments suggest shallow-water deposition and are sedimentologically exotic to this otherwise hemipelagic sequence. This suggests emplacement as fault or slide blocks derived from the Arabian Peninsula margin which lies northwest of this area.

During the Pliocene and Pleistocene, the amount of detrital input differs between Sites 232 and 233. At Site 233 there is a lack of detrital sediment (only a quartzose sand layer at $209.5 \mathrm{~m}$ ), and detrital calcite grains are dispersed throughout the Pliocene section. Moreover, benthonic foraminifera indicate a bathyal environment with no evidence of downslope transport from shallow regions. This suggests that the terrigenous components come from different sources. The siliceous detrital input (Sites 231 and 232) should have come from both the northwest and southwest (south Arabian Peninsula and the horn of Africa) 


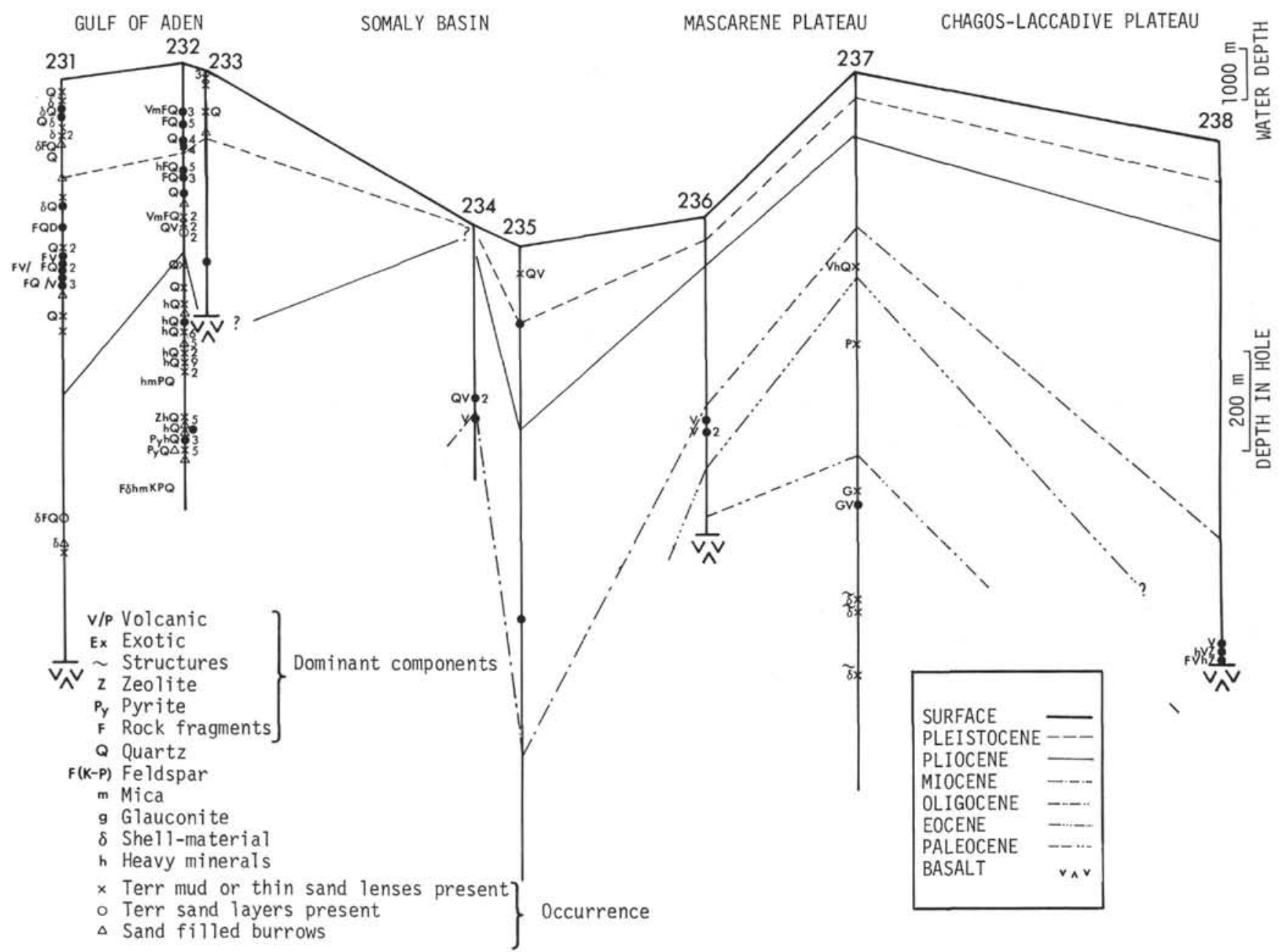

Figure 4. Occurrence of sand layers and lenses at Leg 24 sites.

(Wooster et al., 1967). This is confirmed by volcanogenic components found at the Gulf of Aden sites.

The difference between the Pliocene sections at Sites 232 and 233 could be explained by the transform fault (Alula-Fartak Trench) and its relative movement (200-300 $\mathrm{km}$ from the southwest (?); Lowell and Genik, 1972). The terrigenous input at both sides was carried by wind from different areas (Arabian Peninsula and the horn of Africa).

\section{Terrigenous Sands}

\section{Introduction}

Samples were taken from the top cores at Site 233 to study the mineralogic differences between sands at Site 232 and Site 233 and also to determine possible source areas for these sediments. These sites occur on opposite sides of the Alula-Fartak Trench.

At Site 232, one sample was taken from the Pliocene sand $(14-5,66 \mathrm{~cm})$. Three samples were taken from the sand layers of late, middle, and early Miocene age (6-5, 79 $\mathrm{cm} ; 15, \mathrm{CC}$; and $25, \mathrm{CC}$, respectively). The last sample was taken from the top of the well-lithified sandstone found toward the bottom of this sequence and probably belongs to it. The sample from Site $233(3-2,63 \mathrm{~cm})$ was selected from a sand-rich nannoplankton ooze, 16 meters below the sea floor.

The sand layers have the composition of normal graywacke or quartz arkose (232A-25, CC). The sediments show poor to moderately poor sorting, and the grains are angular to subangular. The sands were sieved, and the fraction above $62 \mu$ was retained for mineralogic study. This fraction was separated into granulometric classes $(\phi)$. Heavy mineral separations were not made. Binocular and polarizing microscopes were used as well as X-ray diffractometry for some samples.

\section{Terrigenous Sediment (Sites 232 and 233)}

Site 232 is located at $14^{\circ} 28.93^{\prime} \mathrm{N}, 51^{\circ} 54.87^{\prime} \mathrm{E}$. Site 233 , on the back slope of the eastern flank of the Alula-Fartak Trench, is located at $14^{\circ} 19.68^{\prime} \mathrm{N}, 52^{\circ}$ 


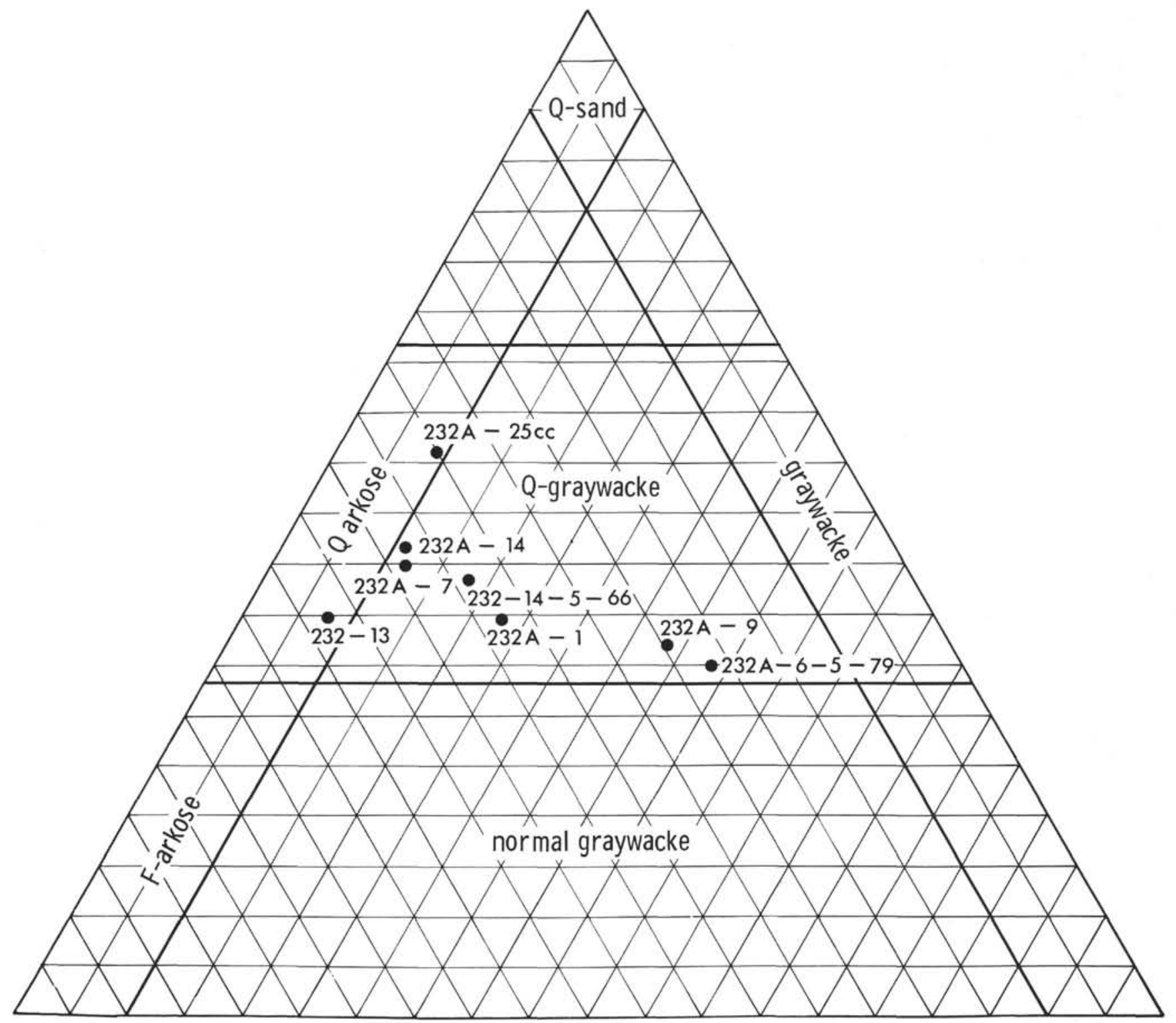

Figure 5. Composition of selected terrigenous standard silt layers.

.08 .11 'E. Both sites are closer to the Arabian coast than to the African coast.

Sedimentation rates during the Recent/Pleistocene/ Pliocene was $55 \mathrm{~m} / \mathrm{m}$.y. and approximately $89 \mathrm{~m} / \mathrm{m}$.y. for the late Miocene at Site 232. At Site 233, sedimentation rates are $45 \mathrm{~m} / \mathrm{m} . \mathrm{y}$. for the Pleistocene and 94-117 m/m.y. for the late Pliocene. At both sites the sedimentation rate after late Pliocene is typical of that for hemipelagic deposition. Increased sedimentation rates during the Miocene and lower Pliocene at Site 232 is presumably due to slumping.

Texture and composition of some selected, representative terrigenous sand and silt layers are given in Figures 5 and 6.

Practically all the sand layers can be grouped together compositionally between feldspar-rich graywacke sands to normal graywacke sands. The sandstone is an exception and is compositionally a quartzose sandstone.
Results from this study of sand mineralogy suggest that the sand layers are uniform with depth in a single hole. Grain size and mineralogy of the sands are shown in Figure 6.

Quartz, mica (prevalently green biotite and occasionally muscovite), and feldspar (plagioclase/K-feldspar ratio 2/1) are the major siliceous constituents of the six samples.

In three of the samples from Site $232(14-5,66 \mathrm{~cm}$; $6 \mathrm{~A}-5,79 \mathrm{~cm}$; and $15 \mathrm{~A}, \mathrm{CC})$ the $250 \mu$ fraction is almost entirely composed of euhedral gypsum; at Site 233 (3-2, 63 $\mathrm{cm}$ ) the coarser fraction is made up exclusively of glauconite.

Quartz grains are remarkably fresh and angular with the exception of Sample 232A-25, CC, where they are subround to round and milky in color. Some grains contain inclusions, but rutile needles, which were observed in quartz grains associated with volcanic ash at this site, were not encountered. 

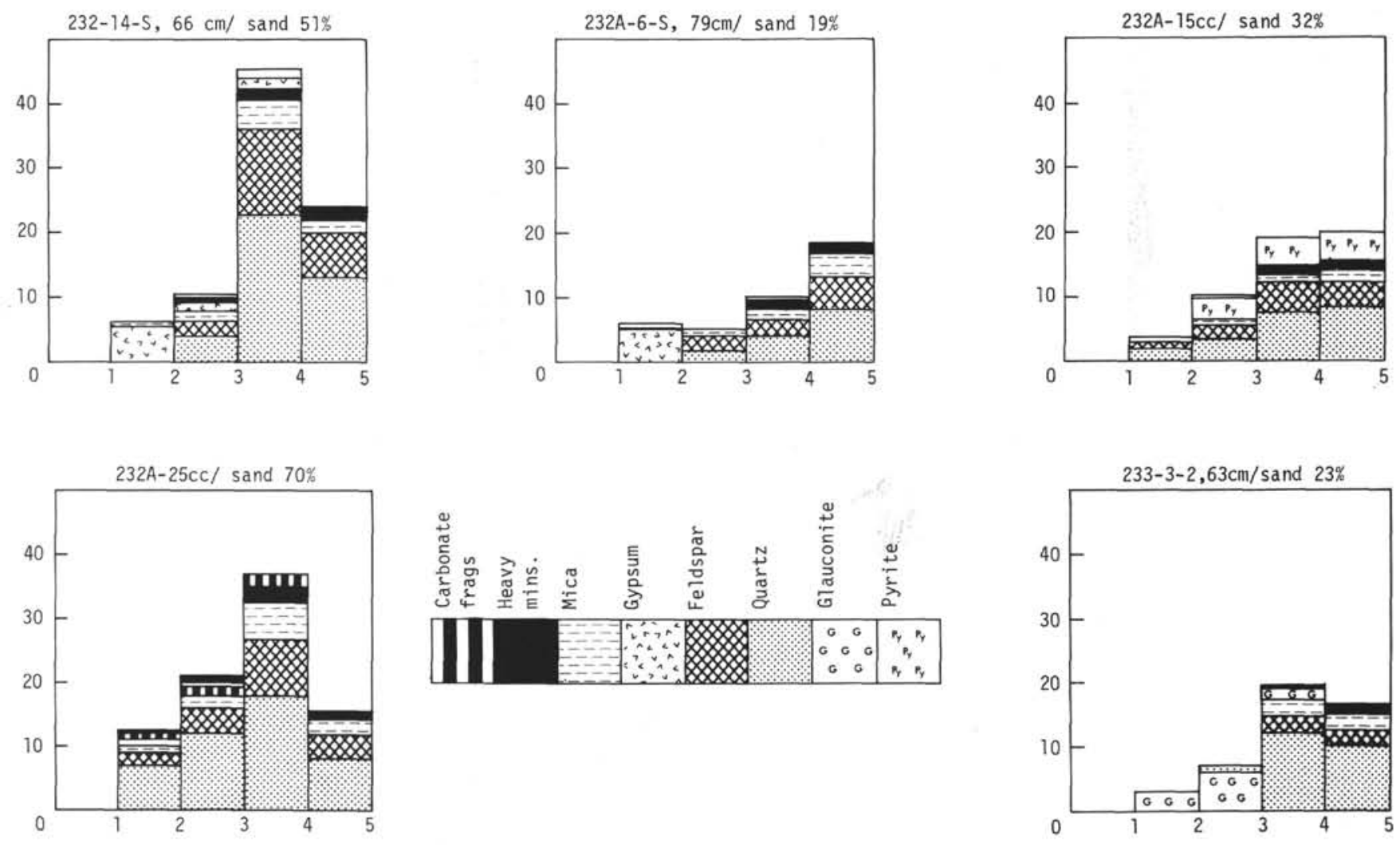

Figure 6. Grain size and mineralogy of sands.

Quartz comprises from $35 \%$ to $45 \%$ of the sand-sized mineral fraction. The lowest quartz percentages occur in Sample 232A-6-5, $79 \mathrm{~cm}$ and Sample 233-3-2, $66 \mathrm{~cm}$. The highest quartz percentage occurs in Sample 232A-25, CC.

Feldspars comprise from $15 \%$ to $25 \%$ of the sand-sized mineral fraction. The lowest percentages occur in Samples 232A-6-5, $79 \mathrm{~cm}$; and 15, CC; and 233-3-2, $63 \mathrm{~cm}$. Highest feldspar percentages occur at $232-14-5,66 \mathrm{~cm}$. Plagioclase and K-feldspars were difficult to differentiate microscopically due to alteration of the grains. In general, X-ray diffractograms show a plagioclase/K-feldspar ratio close to $2 / 1$. Plagioclase feldspar shows an intermediate composition between andesine-bytonite and probably labradorite, as compared to the more sodic composition observed in the plagioclase associated with volcanic ash in this area. $\mathrm{K}$-feldspar is predominantly microcline. X-ray diffraction data from the sand-sized fractions of five samples show the same shape and intensity of feldspar peaks.

Mica group minerals are the third most important group in the Gulf of Aden cores. Normally, green biotite represents the mica mineral present in these samples. Muscovite is present in sediment from Samples 232A-6-5, $79 \mathrm{~cm}$ and $232 \mathrm{~A}-15, \mathrm{CC}$, respectively comprising $9 \%$ and $4 \%$ of the sand-sized mineral fraction. Green biotite comprises from $10 \%$ to $20 \%$ of the sand-sized mineral fraction. The lowest mica percentages $(10 \%)$ occur in Samples 232A-15, CC and 233-3-2, $63 \mathrm{~cm}$. The highest mica percentage (30\%) occurs in Sample 232A-6-5, $79 \mathrm{~cm}$. The green biotite is very rich in dark inclusions, and the flakes are well rounded. The high refractive index (up to
1.62) and X-ray powder diffractometry show it to be an iron-rich biotite belonging to the annite (?) group.

Glauconite is present in the coarse fraction of Samples $232-14-5,66 \mathrm{~cm}$ and $233-3-2,63 \mathrm{~cm}$, respectively comprising $4 \%$ and $12 \%$ of the mineral sand-sized fraction. Glauconite decreases in percentage with grain size, and its major frequency occurs between 62 and $125 \mu$ at Site 232 and between 125 and $250 \mu$ at Site 233. Both samples are from the Plio-Pleistocene section. Glauconite mineral peaks were not observed during X-ray diffractometry, therefore this mineral is present in noncrystalline form.

Glauconite must here be considered an allochthonous material, coming from shallow-water areas and indicating slumping or current transport, probably from the Arabian coast. The appearance of transported material seems to increase toward the top of Site 233.

Gypsum crystals are present at Site $232(14-5,66 \mathrm{~cm}$; $6 \mathrm{~A}-5,79 \mathrm{~cm}$; and $15 \mathrm{~A}, \mathrm{CC}$ ) with percentages of $8 \%, 6 \%$ and $1 \%$, respectively. The occurrence of gypsum decreases with grain size of the sediment. Maximum frequency is found in the $250 \mu$ fraction. Here the gypsum is authigenic with euhedral crystals and small detrital mineral inclusions of mica, quartz, and clay.

Carbonatic or dolomitic rock fragments $(6 \%)$ are present in Sample 232A-25, CC. Some grains are 2-3 mm in size, are well rounded, gray-blue in color, and react slowly to $\mathrm{HCl}$.

Heavy minerals generally comprise less than $9 \%$ of the sand-sized mineral fraction. Green hornblende is the most frequent with its highest percentage (7\%) in Sample $232-14-5,66 \mathrm{~cm}$. Occasionally pyroxene (augite?, 232A-25, 
CC) or apatite $(232 \mathrm{~A}-6-5,79 \mathrm{~cm})$ are present. Zircon, titanite, and epidote minerals are very rare.

Pyrite is present in all the samples examined with the exception of Sample 232A-25, CC. Pyrite becomes very abundant in Sample 232A-15, CC, where it makes up 20\% of the sand fraction. It occurs as yellow crystallized cubes as well as needle-shaped, black, noncrystalline particles. Detrital chlorite is present in Sample 232A-25, CC.

Dolomite is almost always present and occasionally exceeds $5 \%$ of the sample.

\section{Conclusions}

From this preliminary study, some conclusion can be drawn with respect to source areas. The homogeneity and immaturity of the sand are indicated by an almost constant ratio between quartz, feldspar, and mica, which are always present in the Gulf of Aden sediments, and by the abundance of unstable minerals, such as feldspar and amphiboles. Combined with the angularity of most fragments, these data suggest that most of the sediments were derived from an area characterized by quite young relief and rapid erosion. This immature topography occurs along both the Arabian and African coasts of the Gulf of Aden.

The sand layers found at Site 232 were probably transported by wind from the arid region to the Arabian Peninsula. The lack of permanent rivers, the aridity, and the windiness of the region support this hypothesis. Heavy minerals (hornblende, apatite, and pyroxene) are typical of the sand beaches and the sand rivers of the Arabian coast (Einsele and Werner, 1972).

Glauconite, also found at both sites, is typical of shallow-water areas. It is more probable that it came from the closeby Arabian Shelf than from the African Shelf through the Gulf of Aden median valley. Einsele and Werner (1972) found biotite in the Ethiopian sands which was probably transported by wind to this site. Volcanic ash also found at this site suggests a source to the west or northwest (Aisha Horst region, southeast of Djibouti or from the Aden Volcanic Series, from Aden to Wadi Marsila).

The mineral assemblages found are most likely derived from the Precambrian metamorphic rocks of South Yemen and from the intermediate to acid volcanic rocks of the Trapp Series, which covers large areas of Yemen farther to the north (Beydoun, 1970). Supply from Somaliland is possible during the summer monsoons (Bryson, 1968) but, at the present time, we do not have enough information about the mineral assemblage at Site 231, where the sediment input could be coming prevalently from the African Continent.

Goldberg and Griffin (1970) found dolomite in the silt-size fraction in the southern Arabian Sea samples and, under favorable conditions, this can be transported to the marine environment by wind from the arid regions of both Africa and Arabia.

\section{Clay Minerals}

\section{Introduction}

The clay fraction $(<2 \mu)$ of Leg 24 sediments predominantly contains alteration products of volcanic material (montmorillonite and palygorskite) associated with varying percentages of continental detrital clay (mica-illite, kaolinite, and chlorite).

Nonclay detrital minerals are scarce and are mostly composed of quartz and very rare feldspars.

This preliminary work does not consider the fact that detrital clay minerals may change during diagenesis, and alteration products may obliterate all preexisting structure, thus becoming indistinguishable from authigenic phases.

\section{Main Types and Their Occurrence}

The main clay mineral associations and their distribution are illustrated in Figure 7. This shows the dominance of alteration products of volcanic minerals (montmorillonite and palygorskite) and that detrital clay minerals (mica-illite, kaolinite, and chlorite) are generally more abundant in Neogene sediments.

Gulf of Aden: From the early Miocene palygorskite seems to be the more common clay mineral in the Gulf of Aden sediments. A volcanic glass sandy layer (232A-1-4, 40 $\mathrm{cm}$ ) has been found with montmorillonite as the main constituent, an enrichment in kaolinite, but lacking palygorskite. Montmorillonite generally decreases from the bottom of the sections (Sites 231 and 232/232A) towards the top (Plio-Pleistocene).

Mica-illite and kaolinite, both present in small amount during the Miocene, increase towards the Plio-Pleistocene sediments. Chlorite is always present in low percentages ( $0.5 \%$ to $3.0 \%)$ in the Gulf of Aden sediments.

Somali Basin: The Somali Basin sea floor is close to the $\mathrm{CCD}$, and the sediment is characterized by a high clay mineral content. Montmorillonite is always present and represents the main constituent throughout the Miocene, while palygorskite becomes quite important, after montmorillonite, during the Plio-Pleistocene. Palygorskite is absent or rare through the late Oligocene and early Miocene sediments at Site 234, while it is present in the Miocene sediments at Site 235. Mica-illite generally increases towards the Neogene sediments, while kaolinite (Site 234) is abundant and decreases from the Oligocene towards the upper sediments (Plio-Pleistocene). Chlorite is sometimes present in post-middle Miocene sediments.

Mascarene Plateau: At this site (236) montmorillonite is the main component from the Paleocene through the Pleistocene. Palygorskite is generally abundant although it is absent in an Oligocene core $(236-22-4,90 \mathrm{~cm})$. Detrital clay minerals (mica-illite, kaolinite, and chlorite) are absent through the Paleocene until the Oligocene. From the early Miocene mica-illite and kaolinite increase towards the upper sediments. Chlorite is sometimes present in the post middle Miocene sediments.

Chagos-Laccadive Plateau: At this site (238) the ubiquitous montmorillonite is the only component during the Oligocene. Some mica-illite found in the sample $(238-49-2,100 \mathrm{~cm})$ could be formed by alteration of montmorillonite during diagenesis (Dietz, 1942). Palygorskite is only present in considerable amounts in the Pleistocene. Detrital clay minerals become quite important from the ?late Miocene and they increase in the Plio-Pleistocene (mica-illite and kaolinite). Chlorite is absent. 
SEA LEVEL

GULF OF ADEN

SOMALI BASIN

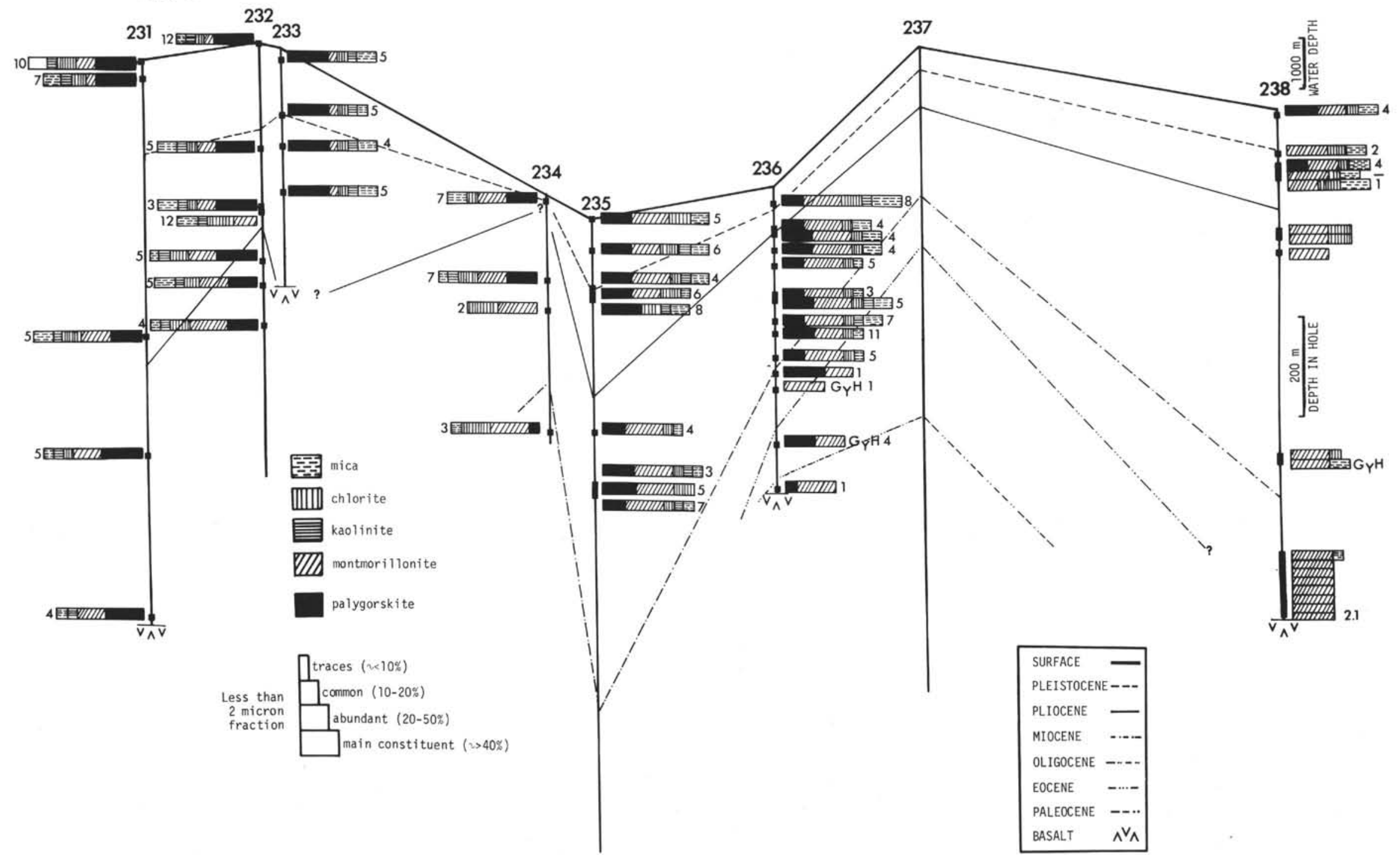

Figure 7. Clay mineral associations and their distribution. 


\section{Source and Transport}

In the northwest Indian Ocean the greatest input of terrigenous sediment is by wind and rivers. The wind systems are intense: the summer monsoons blow persistently from the southwest and this circulation pattern persists between May and September (Wooster et al., 1967). Bryson (1968) found that most of the air which crosses India proper has come from Africa across the Arabian Sea. The main resultant direction of the winter monsoons is from the northeast, is established in November and, persists through February (Wooster et al., 1967). The Indus River, the most important example of river input, drains the Himalayas as well as a large area of semi-arid land (West Pakistan and northwest India).

Heezen et al. (1965) found palygorskite (attapulgite) increasing in abundance going from the Red Sea through the Gulf of Aden into the Arabian Sea. Goldberg and Griffin (1970) found the same clay mineral decrease going from Africa. They suggested the arid region of northeast Africa as the more reasonable source area, and palygorskite may very well be a tracer for eolian input into the Indian Ocean. However, Müller (1961) reported palygorskite in the fluvial sediments from wadies in southern Arabia, which he suggested as being the source of this clay mineral. Palygorskite has been found in deep-sea sediments by various authors, and the problem of its origin in this kind of environment is still open (Hollister, Ewing et al., 1972). In Leg 24 cores, palygorskite was found in high concentration in the Gulf of Aden sediments, decreasing in the Somali Basin area. This suggests that probably both northeast Africa and southern Arabia are sources of this wind-transported clay mineral.

Goldberg and Griffin (1970) found montmorillonite increases in abundance in the $<2 \mu$ size fraction as the peninsular coast of India is approached, apparently as a result of weathering of basaltic rocks of the Daccan Traps and subsequent fluvial transport.

Moreover, high percentages of montmorillonite were found along a narrow belt from Réunion and Mauritius islands to south Chagos-Laccadive Ridge and most probably result from the alteration of volcanic debris in place. This could be considered a second important source of montmorillonite for the central West Indian Ocean, with the Arabian coast towards the north being a third one. At the Chagos-Laccadive Ridge (Site 238) and the Mascarene Plateau (Site 236), the very high percentages of montmorillonite could be considered primarily of autochthonous origin.

However, for the Gulf of Aden and Somali Basin sediments, a source of montmorillonite could be the south Arabian Peninsula, where weathered intermediate to acid volcanic rocks of the Trapp Series (Upper Cretaceous/ Tertiary, Beydoun, 1970) cover large areas. The winter monsoons can very well be used to explain the ample distribution of montmorillonite from the early Miocene.

Goldberg and Griffin (1970) show that the main source of mica-illite is the north Arabian Sea coast (Pakistan and India) and they are probably carried either by the Indus River or by dust-bearing winds. Consequently, they both exhibit high concentrations in the northern area. In the Leg
24 sediments mica-illite increases from Miocene to Plio-Pleistocene time, while its level is more or less uniform at all sites. As in the western region (Gulf of Aden), this input appears to be carried to the equatorial regions of the Indian Ocean prevalently from the desert region of northern India and West Pakistan.

Because chlorite appears when other detrital clay minerals (i.e., mica-illite) increase in abundance, the chlorite is probably of detrital origin. It decreases from the Gulf of Aden to the Central Indian Ridge, where it disappears in the whole section (Site 238). This does not agree with Goldberg and Griffin (1970), who suggested that chlorite is associated with volcanic material.

Goldberg and Griffin (1970) found the northwest Indian Ocean surface sediments poor in kaolinite. A small increase of this clay mineral was found around the more acidic rocks of the north Mascarene Plateau. This could explain the small increase in kaolinite in sediments of the Somali Basin.

\section{Conclusions}

Eolian and fluvial inputs to the northwest Indian Ocean play a very important role. On the basis of work by Goldberg and Griffin (1970) and the clay mineral distributions in the $<2 \mu$ size fraction of the present study, it has been possible to recognize the main source and method of transportation.

The main source of palygorskite is northeast Africa and the Arabian Peninsula from where it is wind transported.

Some montmorillonite comes from the Indian Peninsula and from alteration of volcanic debris from an area between Reunion and Mauritius islands to Chagos Islands. At Sites 236-238 it has an autochthonous origin as well. The Arabian Peninsula is the primary source for the Gulf of Aden and Somali Basin sediments.

Detrital clay minerals (mica-illite, kaolinite, and chlorite) appear to be primarily windborne from the desert area of northern India and West Pakistan, as is demonstrated by their low percentages in all the areas studied and their increase in the Neogene sediments, starting with the intense drainage from these lands after the Himalayan diatrophism.

\section{Volcanogenic Components}

\section{Introduction}

Sand and silt-sized volcanic ashes consisting principally of glass fragments associated with fragments of volcanic rock, pumice, and palagonite were found at 38 levels during Leg 24. They occur predominantly as beds, as pockets, or as scattered shards. Their occurrence, depth, and probable age are given in Table 2.

Only 5 of the 38 volcanic ashes were altered, the remaining horizons containing unaltered glass. Fresh volcanic ash is characterized by splinters, fibers, bubble walls, and, more rarely, by cellular pumice fragments. The shards are predominantly angular with concoidal fractures. Some glass fragments frequently contain gas bubbles or, more rarely, small, embryonic crystals. The initial devitrification is marked by development of aggregate polarization (with low birefringence). The complete devitrification (altered glass) is from glass to clay. 
TABLE 2

Major Volcanic Contributors

\begin{tabular}{|c|c|c|c|c|c|c|}
\hline Site-Core-Section & $\begin{array}{l}\text { Depth } \\
\text { (m BSF) }\end{array}$ & Type & Glass & $\begin{array}{l}\text { Color } \\
\text { Glass }\end{array}$ & Probable Age & Remarks \\
\hline $231-20-2$ & 170 & Ash bed & 1.502 & Colorless & Lower Pliocene & Volcanic ash sand \\
\hline $231-21-2$ & 180 & Ash pocket & - & Colorless & Lower Pliocene & Volcanic ash sand \\
\hline $231-22-1$ & 188 & Ashy sediment & - & Colorless & Lower Pliocene & Volcanic ash sand \\
\hline $231-23-5$ & 203 & Ash bed & - & Colorless & Lower Pliocene & Altered volcanic glass \\
\hline $232-17-\mathrm{CC}$ & 155 & Ashy sediment & & Colorless & Lower Pliocene & Glass equals $10 \%$ of sediment \\
\hline $232 \mathrm{~A}-1-4$ & 164 & Ash bed & 1.511 & Colorless & Lower Pliocene & Volcanic ash sand \\
\hline $232 \mathrm{~A}-1-5$ & 165 & Ash bed & - & Colorless & Lower Pliocene & Nanno volcanic ash sand \\
\hline $233 A-4-66$ & 206 & Ashy sediment & 1.510 & Colorless & Lower Pliocene & Glass equals $10 \%$ of sediment \\
\hline $234-11-2$ & 173 & Ashy sediment & 1.502 & Colorless & Lower Miocene & Nanno-rich volcanic ash sand \\
\hline 234-11-3 & 174 & Ashy sediment & - & Colorless & Lower Miocene & Nanno-rich volcanic ash sand \\
\hline $234-13-3$ & 194 & Ashy sediment & - & Colorless & Lower Miocene & Clay-rich volcanic ash silt \\
\hline $235-3-3$ & 23 & Ashy sediment & 1.503 & Colorless & Pleistocene & Nanno ash quartz sand \\
\hline $236-22-1$ & 198 & Ash pocket & - & Colorless & Upper Oligocene & Pocket in semilithified chalk is palagonite \\
\hline $236-23-4 / 5$ & 212 & Ash bed & - & Colorless & Upper Oligocene & Pocket in semilithified chalk is palagonite \\
\hline $236-23-6$ & 214 & Ash bed & - & Colorless & Upper Oligocene & 2 volcanic ash layers-Palagonite \\
\hline $237-21-2$ & 189 & Ashy sediment & - & Colorless & Upper Oligocene & Hard layers, glass $5-10 \%$ of sediment \\
\hline $237-29-2$ & 266 & Ashy sediment & - & Brown/colorless & Middle Eocene & 2 Palagonite $(5-10 \%)$ layers \\
\hline $237-44-2$ & 414 & Ash bed & - & Colorless & Upper Paleocene & Volcanic glass silty clay-black layers \\
\hline $237-48-1$ & 450 & Ashy sediment & - & Colorless & Upper Paleocene & Glass equals $5 \%$ of sediment \\
\hline $237-52-1$ & 488 & Ashy sediment & _ & Colorless & Upper Paleocene & Glass equals $5 \%$ of sediments \\
\hline $237-53-2$ & 500 & Ashy sediment & - & Colorless & Upper Paleocene & Glass equals $5-10 \%$ of sediments \\
\hline $237-59-1$ & 555 & Ashy sediment & - & Colorless & Upper Paleocene & Glass equals $5 \%$ of sediments \\
\hline $238-52-3$ & 484 & Ashy sediment & - & Colorless & Upper/Lower Oligocene & Volcanic glass-rich clay \\
\hline $238-52=4$ & 486 & Ash bed & 1.515 & Colorless & Upper/Lower Oligocene & Volcanic ashy sand \\
\hline $238-52-5$ & 487 & Ash bed & 1.512 & Colorless & Upper/Lower Oligocene & Volcanic ash sand in green clay \\
\hline $238-53-2$ & 492 & Ashy sediment & 1.510 & Colorless & Upper/Lower Oligocene & $3-\mathrm{cm}$ layers of sand volcanic-rich nanno marl \\
\hline $238-53-2$ & 492 & Ash bed & 1.520 & Brown & Upper/Lower Oligocene & $5-\mathrm{cm}$ layer of nanno-rich volcanic ashy sand \\
\hline $238-53-2$ & 492 & Ash bed & 1.518 & Brown & Upper/Lower Oligocene & $5-\mathrm{cm}$ layer of nanno-rich volcanic ashy sand \\
\hline $238-53-2$ & 493 & Ashy sediment & 1.515 & Colorless & Upper/Lower Oligocene & Fe-oxide-sandy volcanic ashy marl \\
\hline 238-53-2 & 493 & Ashy sediment & 1.515 & Colorless & Upper/Lower Oligocene & Fe-oxide-sandy volcanic ashy marl \\
\hline $238-53 \cdot 3$ & 494 & Ashy sediment & 1.514 & Colorless & Upper/Lower Oligocene & Volcanic ash-rich nanno-marl \\
\hline $238-53-3$ & 494 & Ash bed & 1.513 & Colorless & Upper/Lower Oligocene & Volcanic ashy sand \\
\hline $238-53-3$ & 494 & Ash bed & 1.518 & Brown & Upper/Lower Oligocene & Nanno-rich volcanic ash sand \\
\hline $238-53-3$ & 495 & Ash bed & 1.518 & Brown & Upper/Lower Oligocene & Nanno-rich volcanic ash in green clay \\
\hline $238-54-1$ & 500 & Pumice/rocks bed & - & & Upper/Lower Oligocene & Rock fragments present \\
\hline 238-54-1 & 501 & Zeolite sand bed & - & & Upper/Loewer Oligocene & Zeolite sand \\
\hline $238-54-1$ & 501 & Zeolite bed & - & & Upper/Lower Oligocene & \\
\hline
\end{tabular}




\section{Occurrence}

Ash layers were recognized most frequently in the Gulf of Aden (8 levels) at Sites 231, 232, and 233; Mascarene Plateau ( 7 levels) at Site 237; and south Chagos-Laccadive Ridge (15 levels) at Site 238; while less-frequent ash layers were found in the Somali Basin (4 levels) at Sites 234, 235; and north of the Mascarene Plateau (3 levels) at Site 236.

Fresh, clear, and angular volcanic ash occurs predominantly in the Gulf of Aden and the Somali Basin, but becomes altered (devitrification) towards the Central Indian Ridge (Mascarene and Chagos-Laccadive plateaus.) In most of the cases, the volcanic ash layers were found to be concentrated within a few meters at each site. The presence of the glass fragments at each site shows a marked difference in age from west to east, the older being found in the east, Figure 8.

In the Gulf of Aden, ash layers were found at depths between 170 and 203 meters at Site 231, between 155 and 165 meters at Site 232, and at a depth of 206 meters at Site 233 , all occurring in nanno ooze of lower Pliocene age.

Correlations among volcanic ash layers are not possible in the Somali Basin because of the low recovery at Site 235. Ashy sediments (of lower Miocene age) were found at Site 234 at a depth of between 173 and 194 meters below sea floor (BSF).

The greatest concentrations of volcanic ash were found at Site 238, just above the basalt. The sequence was found between a depth of 484 and 501 meters BSF (Oligocene). An ashy sediment horizon was found at Site 237 at 188 meters BSF (Oligocene), and three layers were found at Site 236 between 198 and 214 meters BSF (Oligocene).

The oldest volcanic ash sediments of upper Paleocene age were found at Site 237 (Mascarene Plateau) at a depth between 414 and 555 meters BSF.

\section{Texture}

The texture, Figure 9, of the volcanogenic sediments generally ranges from sand to sandy silt for the Gulf of Aden, Somali Basin, and Chagos-Laccadive Ridge sites, whereas clay silt and silty clay are typical of Site 237 on the Mascarene Plateau. In general, the degree of sorting is poor.

\section{Volcanic Glass Composition}

The $\mathrm{SiO}_{2}$ content of the volcanic glass was determined by its refractive index, using the relationship between silica content and refractive index of volcanic glasses described by W. O. George (Williams et al., 1954). The refractive index of glass normally ranges from 1.48 to 1.61 (Krumbein and Pettijohn, 1938) and increases with a decrease of $\mathrm{SiO}_{2}$. The refractive indexes of the present glasses were determined by standard methods, using liquids of known refractive index. The expected error of the refractive index measurement is 0.003 . This is about the range of variation within individual ash and pumice deposits with a refractive index less than 1.515. Individual variation is greater than the probable error when the refractive index is greater than 1.515 (Challis, 1962). In each sample at least three shards were measured.

Significant regional variations have been shown for the refractive index measurement, while at the same site and region, the data are uniform (Table 1).
In the Gulf of Aden there are two kinds of glass: one having $n$ around $1.502\left(72 \% \mathrm{SiO}_{2}\right)$ and the other having values of $n$ averaging around $1.510\left(67 \% \mathrm{SiO}_{2}\right)$. According to Challis (1962) and Van der Lingen (1968), shards of such low refractive index are rhyolitic (n 1.502), while those with a refractive index slightly higher than 1.510 are andesitic. Like Challis (1962) we found that a clear separation of the refractive index enables division into two groups.

In the Somali Basin, a Pleistocene sample from Site 235 shows a refractive index of $1.503\left(72 \% \mathrm{SiO}_{2}\right)$ and is rhyolitic in origin. The lower Miocene samples from Site 234 have the same refractive index, indicating a similar rhyolitic origin.

In the Oligocene sequence on the Mascarene and Chagos-Laccadive plateaus (Sites 236, 237, 238), the refractive index of the volcanic glass ranges between 1.511 $\left(67 \% \mathrm{SiO}_{2}\right)$ and $1.520\left(63 \% \mathrm{SiO}_{2}\right)$, with an average of 1.516. Here the volcanic glass is colorless, brown, or green with an $\mathrm{SiO}_{2}$ content of $65 \%$. This suggests a source rock slightly more basic than andesite.

No refractive index measurements are available for the paleocene sequence at Site 237, where we found an advanced devitrification process, with small amount of semi-altered glass $(5 \%-10 \%)$ and an increase of zeolites, bentonite, and palygorskite clay.

\section{Coarse Fraction: Major Minerals Associated with Volcanic Ash}

After drying the samples were treated with $6 \mathrm{~N} \mathrm{HCl} \mathrm{until}$ effervesence ceased. The coarse $(>0.062 \mathrm{~mm})$ and the fine fraction were separated by sieving, and the coarse fraction of each sample was examined by binocular and petrographic microscopes.

The mineralogical composition of the volcanogenic sequences are shown in Table 3 .

In the Gulf of Aden, the mineralogical composition is characterized by green mica (biotite), quartz, and feldspar (predominantly plagioclase An $>50 \%$ ). The mica is the most common terrigenous component (10\%-20\%). It is present in flakes with well-rounded edges, green in color and very rich in dark inclusions. The refractive index is very high (1.62-1.63) and X-ray diffractograms show it to be an iron-rich biotite. The quartz $(10 \%-40 \%)$ is present predominantly in subangular grains, commonly rich in gaseous and mineral (rutile) inclusions. The feldspars (5\%-12\%) are mainly semi-altered plagioclase, and are associated both with quartz and mica, and are probably detrital. The low degree of alteration, low refractive index (1.53-1.54), and X-ray diffractograms show enrichment in $\mathrm{Na}$ (albite-andesine). Heavy minerals are almost absent in the volcanic ash sediments, but some rare detrital grains of green horneblend and augite were found.

In the Somali Basin, the volcanic ash layers contain less quartz $(5 \%-10 \%)$ and mica $(5 \%-20 \%)$, but more feldspar (50\%) than in the Gulf of Aden. Quartz and mica have the same physical and optical characteristics as did the samples from the Gulf of Aden. The feldspar is also mainly plagioclase, but of a different appearance with very clear unaltered tubular crystals showing the typical twinning following the albite law and with a low refractive index (1.53). Heavy minerals are very rare. 
At Sites 236 and 237 on the Mascarene Plateau, zeolites have been observed in association with volcanic ash in Sample 236-23-6, 214 meters BSF and 237-48-1-80, 450 meters BSF ( $10 \%$ and $40 \%$, respectively). X-ray diffraction shows it to be zeolite species p of the phillipsite group (Table 3). In Sample 237-51-2-10, 781 meters BSF clinoptilolite made up more than $50 \%$ of the coarse fraction with about $10 \%-15 \%$ glauconite.

South of Chagos-Laccadive Ridge at Site 238, the volcanogenic sequence is dominated in almost all the samples by feldspars but towards the bottom of the cores, zeolite can be very important (e.g. 51-3-92, 484 m BSF; 53-3-126, 595 m BSF; 54-1-84, 596 m BSF; and 54-1-90, $596 \mathrm{~m}$ BSF). The feldspars are mainly plagioclase with a high refractive index (1.56-7) and could be classified between labradorite and anorthite. Zeolite belongs to the same group found at Site 237 (i.e., phillipsite). Occasional important occurrences of heavy minerals were observed predominantly of the pyroxene group: augite and hypersthene and basaltic rock fragments, respectively, in cores (238-54-1-50; 238-54-1-84; 238-54-1-30).

\section{Discussion and Conclusions}

1. Thirty-eight volcanic ash horizons have been observed in the Leg 24 cores with more than 5\%-10\% volcanogenic debris. Twelve of these horizons are made up of more than $50 \%$ volcanic glass shards.

2. The $\mathrm{SiO}_{2}$ content of the volcanic glass shows regional variation between $72 \%-63 \%$, the glass being enriched in $\mathrm{SiO}_{2}$ in the Gulf of Aden and Somali Basin (72\%-67\%). This glass appears to belong to both the rhyolitic and andesitic lavas. The glass in most of the sediments of Mascarene and Chagos-Laccadive plateaus appears to belong to lavas slightly more basic, with less $\mathrm{SiO}_{2}(67 \%-62 \%)$.

3. The volcanism, as suggested by the stratigraphic occurrence of the ash layers (Figure 8) in the northwestern Indian Ocean may have migrated from the Central Indian Ridge during the Paleocene, towards the northwest until the lower Pliocene. After a decrease in occurrence during the Eocene, marked only by local volcanic manifestations (Mascarene Plateau), the volcanism increased again during the Oligocene in an area between the south Chagos-Laccadive Ridge to the north Mascarene Plateau.

During the Miocene the volcanism moved toward the northwest to the Somali Basin, and again during the Pliocene to the Gulf of Aden, where we found the last strong volcanic activity.

4. A perplexing problem arises when one queries the origin of the medium glasses $(67 \%-62 \%)$ occurring in deep water far from land (Central Indian Ridge). (a) It has been observed that most common glassy rocks are formed by the rapid cooling of the more viscous lavas, such as rhyolite, whereas basic lavas remain relatively fluid at low temperatures and tend to produce crystals. (b) Vallier (1970) from volcanogenic sequences found during Leg 5 explained that the ash could have been carried by wind or density currents from land. At present this seems to be the best answer for the Indian Ocean volcanogenic sequences, and with a more precise knowledge of the geographic land distribution during the Paleocene and Oligocene periods this hypothesis could be confirmed.
5. The coarse fraction associated with volcanogenic ash changes in composition from the Gulf of Aden, which is rich in terrigenous materials (quartz, mica, and feldspar) through the Somali Basin, which is richer in feldspar (albite) and at the Mascarene and Chagos-Laccadive plateaus, where calcic plagioclase (labradorite-anorthite) and zeolites (phillipsite and clinoptilolite) are the most important components, while quartz disappears.

6. The volcanic horizon of lower Pliocene age found at Hole 233A at a depth of 206 meters BSF may correlated with volcanic ash layers of Sites 231 and 232, which are lower Pliocene in age as well. This suggests that the opening of the Alula-Fartak Trench postdates the lower Pliocene.

7. The acidic volcanic glass in the Gulf of Aden could be derived from the Pliocenic rhyolite southeast of Djibouti, while the andesinic glass could be derived from the Pliocene-Recent Aden Volcanic Series, which exhibits mixed rocks and occurs quite extensively in the western part of southern Arabia (Beydoun, 1970).

8. The origin of the gypsum in the Gulf of Aden is open to many interpretations; however, the most plausible is authigenic in clay.

\section{Authigenic components}

Authigenic minerals are rare in Leg 24 deposits. However, those varieties present include zeolites, barite, gypsum, manganese nodules and micronodules, iron oxides, palygorskite, pyrite, chert, and calcite. Each will be considered separately.

\section{Zeolites}

Phillipsite is the principal zeolite occurring in Leg 24 sediments, with clinoptilolite present in lesser concentrations. These minerals are largely absent from the Gulf of Aden and Somali Basin where terrigenous sedimentation is important, but reach quite high concentrations in the southern Indian Ocean sediments far removed from land. At Site 236, phillipsite is concentrated into the $2-20 \mu$ fraction, where it comprises up to $30 \%$ of the sediment. Clinoptilolite, which is subordinated to phillipsite in the bulk sediments, is largely present in this fraction, although some also occurs in the clay fraction. Phillipsite reaches a maximum abundance in Site 238 of $35 \%$, but clinoptilolite does not exceed $1 \%$. This high concentration is in the basal sediments, where it comprises as much as $100 \%$ of the $2-20 \mu$ fraction. The association of phillipsite with the products of submarine volcanism in these sediments, such as volcanic glass and igneous minerals, is similar to its associations in deep-sea sediments generally, and probably indicates a genetic link between the two.

\section{Barite}

Barite is seemingly absent from all Leg 24 sites except Site 236, where it occurs in concentrations of up $2 \%$ in the $2-20 \mu$ fraction. This lack of barite is somewhat problematic in view of its widespread distribution in Pacific sediments from similar latitudes (Cronan, 1973), but might be partly due to the higher sedimentation rates in the western Indian Ocean than over much of the Pacific. Its lack of detection in the Gulf of Aden and Somali Basin cores could also be due to the relatively high concentrations of dilutent 


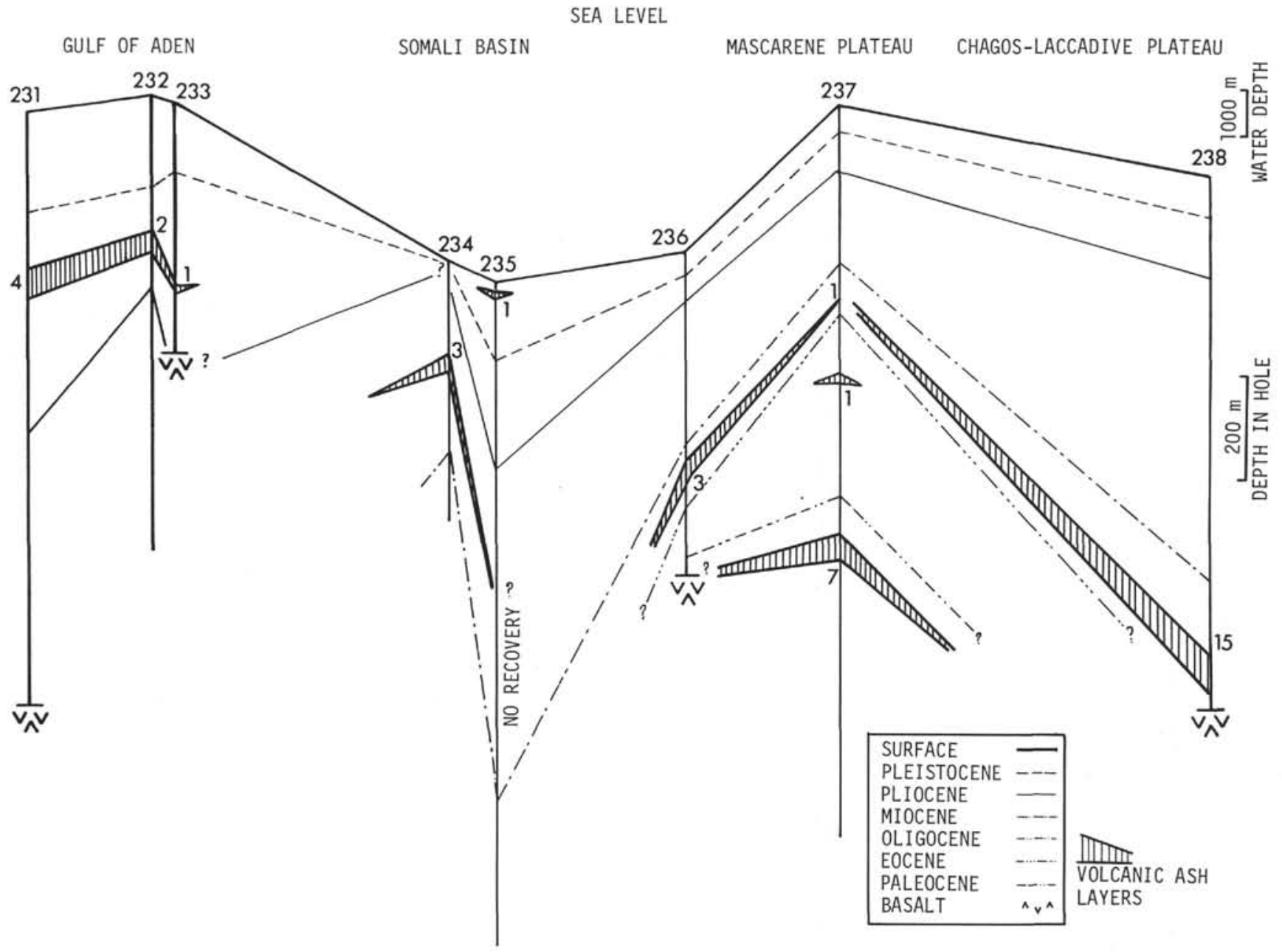

Figure 8. Distribution of volcanic ash layers in Leg 24 sites.

terigenous minerals in these deposits. The sediments in which it does occur were obtained within the equatorial zone, supporting the association between barite and high carbonate productivity noted by Goldberg and Arrhenius (1958) and Church (1970). Interestingly, no detectable barite was associated with the volcanic debris at the base of Site 238.

\section{Gypsum}

Gypsum was recorded in the $<2 \mu$ fraction at the following sites and depths:

\begin{tabular}{rcrrr}
\hline Site & Core & $\begin{array}{c}\text { Depth } \\
(\mathrm{m})\end{array}$ & $\begin{array}{c}\text { Gypsum } \\
(\%)\end{array}$ & $\begin{array}{c}\text { Halite } \\
(\%)\end{array}$ \\
\hline 236 & 22 & 201.9 & 20.7 & 3.2 \\
236 & 29 & 264.4 & 35.5 & 10.5 \\
238 & 38 & 355.0 & 39.9 & 34.3 \\
238 & 53 & 495.7 & 6.9 & 1.4 \\
238 & 54 & 500.2 & 14.0 & 8.1 \\
\hline
\end{tabular}

Sites 236 and 238 are located in the open ocean and the likelihood of evaporite formation having occurred here is surely remote. The constant association of halite with the gypsum and the sympathetic variation in the gypsum: halite ratio suggests these two minerals to be artifacts, probably generated by precipitation from evaporated interstitial fluids during sample preparation.

One further occurrence of gypsum was determined in $233 \mathrm{~A}-4, \mathrm{CC}$ at $206 \mathrm{~m}$. This gypsum is also most likely to be an artifact.

\section{Ferromanganese Oxide Deposits}

Manganese nodules and micronodules are rare in Leg 24 sediments. One nodule approximately $3 \mathrm{~cm}$ in diameter was obtained from the top of Site 234, but this was the only one encountered during the whole cruise. Micronodules were also rare in the sediments, except near the base of Site 238 where they were associated with zeolites and the products of submarine volcanism. Ferromanganese oxides reach their greatest abundance either in very slowly accumulating sediments or in the vicinity of submarine volcanic activity (Cronan, in press). Their low concentrations in the Leg 24 deposits, other than at Site 238 , could be due to neither of these conditions being fulfilled at present throughout most of the western Indian Ocean.

\section{Iron Oxides}

Grains and globules of amorphous iron oxides only occur in any abundance in the basal sediments of Site 238, where they constitue a sizable fraction of the sediment. The 
TABLE 3

Coarse Fraction Volcanic Ash Sediment: Major Mineral Contributors

\begin{tabular}{|c|c|c|c|c|c|c|c|c|c|c|c|c|c|c|}
\hline \multirow[b]{2}{*}{ Site-Core-Section } & \multirow{2}{*}{$\begin{array}{l}\text { Depth } \\
\text { (m BSF) }\end{array}$} & \multirow[b]{2}{*}{ Glass } & \multirow[b]{2}{*}{ Pumice } & \multirow{2}{*}{$\begin{array}{c}\text { Rock } \\
\text { Fragments }\end{array}$} & \multirow[b]{2}{*}{ FerOxide } & \multicolumn{2}{|c|}{ Zeolites } & \multirow[b]{2}{*}{ Quartz } & \multirow[b]{2}{*}{ Plagioclase } & \multirow[b]{2}{*}{ Feldspar } & \multirow[b]{2}{*}{ Mica } & \multirow{2}{*}{$\begin{array}{c}\text { Heavy } \\
\text { Minerals }\end{array}$} & \multirow[b]{2}{*}{ Pyrite } & \multirow[b]{2}{*}{ Glauconite } \\
\hline & & & & & & Phillipsite & Clinoptilolite & & & & & & & \\
\hline $232-17, \mathrm{CC}$ & 155 & $\mathrm{C}$ & VR & & VR & & & C & $\mathrm{S}$ & $\mathrm{R}$ & A & $\mathrm{R}$ & $\mathbf{R}$ & VR \\
\hline $232 \mathrm{~A}-1-4$ & 164 & A & & & & & & s & $\mathrm{R}$ & VR & $\mathrm{s}$ & VR & & \\
\hline $233 \mathrm{~A}-4, \mathrm{CC}$ & 206 & $\mathrm{~s}$ & & & & & & S & $\mathrm{R}$ & VR & $\mathrm{R}$ & VR & VR & VR \\
\hline $234-11-2$ & 173 & $\mathrm{R}$ & & & VR & & & s & A & $\mathrm{S}$ & & VR & VR & VR \\
\hline $234-13-3$ & 194 & $\mathrm{R}$ & & VR & VR & & & $\mathrm{S}$ & A & C & & VR & & \\
\hline $235-3-3$ & 23 & $\mathrm{~s}$ & & VR & & & & VR & $\mathrm{R}$ & $\mathrm{R}$ & A & & VR & \\
\hline $236-23-6$ & 214 & A & & & VR & & $\mathrm{R}$ & $\mathrm{R}$ & VR & VR & & & & \\
\hline $237-48-1$ & 450 & $\mathrm{~s}$ & & & $\mathrm{R}$ & C & & & $\mathrm{R}$ & $\mathrm{R}$ & & & & VR \\
\hline $237-51-2$ & 781 & $\mathrm{~S}$ & & & & & A & VR & s & $\mathrm{R}$ & & VR & & $\mathrm{C}$ \\
\hline $238-51-3$ & 484 & VR & & $\mathrm{s}$ & S & A & & & C & $\mathrm{R}$ & $\mathrm{C}$ & VR & & \\
\hline $238-52-3$ & 484 & $\mathrm{~s}$ & & & & & & & A & C & & $\mathrm{S}$ & & \\
\hline $238-52-4$ & 486 & A & & & & $\mathrm{R}$ & & VR & A & $\mathrm{s}$ & & $\mathrm{s}$ & & \\
\hline $238-52-5$ & 487 & A & & & $\mathrm{R}$ & $\mathrm{R}$ & & & C & $\mathrm{R}$ & & $\mathbf{R}$ & & \\
\hline $238-53-2$ & 492 & A & & & & & & & C & & & & & \\
\hline $238-53-2$ & 492 & A & & & VR & VR & & & C & VR & & & & \\
\hline $238-53-2$ & 492 & $\mathrm{~A}$ & & & & VR & & & $\mathrm{R}$ & VR & & VR & & \\
\hline $238-53-2$ & 493 & $A$ & & & $\mathrm{~s}$ & $\mathrm{R}$ & & VR & $\mathrm{s}$ & $\mathrm{R}$ & & & & \\
\hline $238-53-2$ & 493 & A & & & $\mathrm{s}$ & & & VR & $\mathrm{R}$ & VR & & & & \\
\hline $238-53-3$ & 494 & C & & & $\mathrm{s}$ & VR & & & $\mathrm{C}$ & & & $\mathrm{C}$ & & \\
\hline $238-53-3$ & 494 & A & & & $\mathrm{R}$ & & & & $\mathrm{s}$ & VR & & $\mathrm{R}$ & & \\
\hline $238-53-3$ & 495 & $\mathrm{C}$ & & & $\mathrm{R}$ & A & & & & & & $\mathrm{R}$ & & \\
\hline $238-54-1$ & 500 & VR & VR & A & VR & $\mathrm{R}$ & & & $\mathrm{s}$ & $\mathrm{s}$ & & C & & \\
\hline $238-54-1$ & 501 & VR & & $\mathrm{R}$ & & A & & VR & $\mathrm{C}$ & $\mathrm{s}$ & & $\mathrm{s}$ & & \\
\hline $238-54-1$ & 501 & VR & & VR & & A & & & $\mathrm{s}$ & s & & $\mathrm{s}$ & & \\
\hline
\end{tabular}

Note: $\mathrm{A}=$ abundant $\mathrm{C}=$ common $; \mathrm{S}=$ scattered $\mathrm{R}=$ rare $; \mathrm{VR}=$ very rare. 


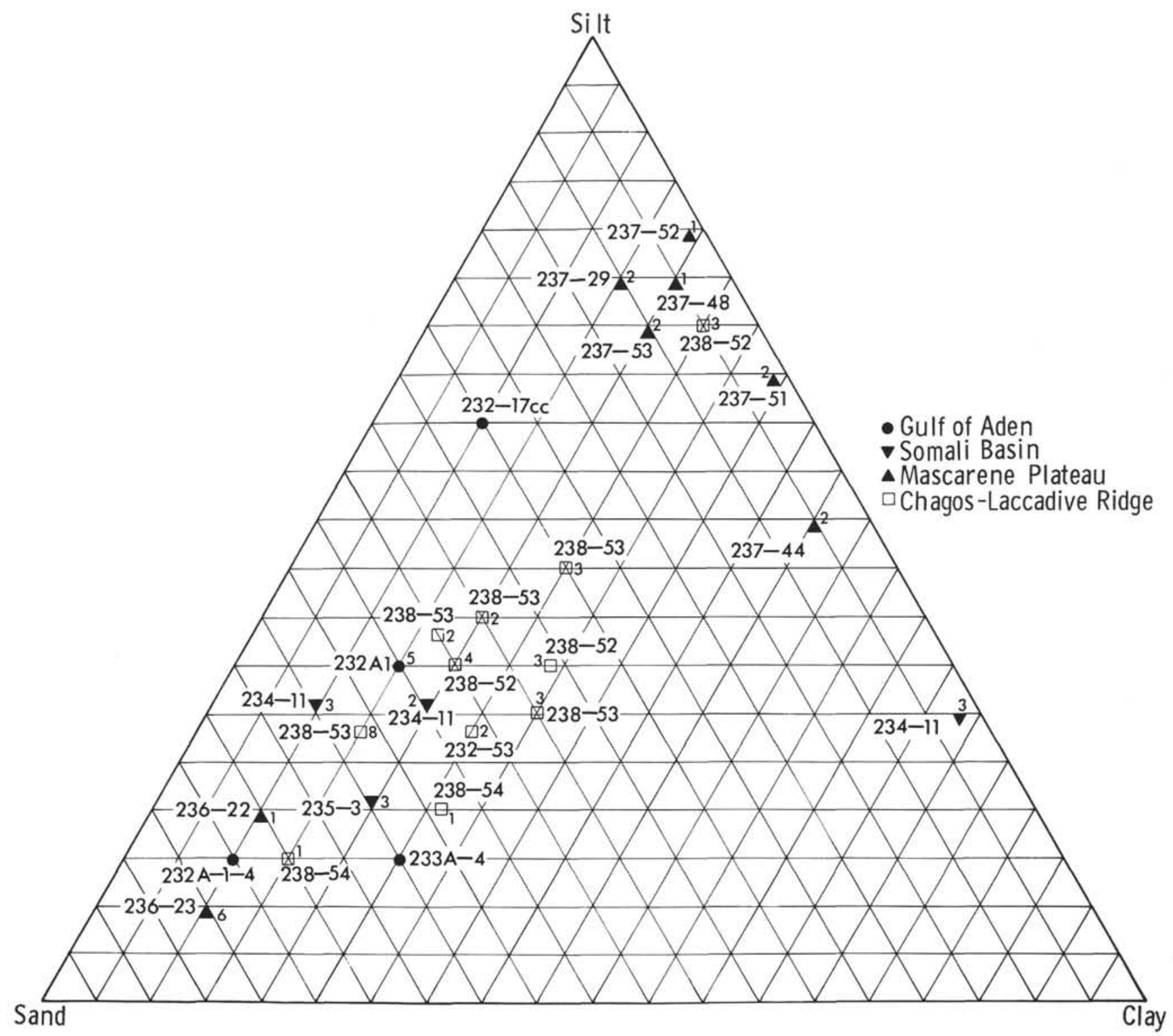

Figure 9. Textural distribution of volcangenic sediments.

particles range in diameter from a few microns to a few tens of microns, and are yellow to reddish-brown in color. These oxides constitute the basal metalliferous facies of these sediments and will be discussed under this heading in the next section of this chapter.

\section{Palygorskite}

Most clay minerals in deep-sea sediments are detrital in origin, and thus fall outside the scope of this section. However, the mineral palygorskite is considered to authigenic in origin by some workers and occurs in many of the sediments obtained during Leg 24. It is present in all the sites from the Gulf of Aden and Somali Basin. Maximum concentrations in bulk sediments of near $40 \%$ occur at Site 231, where it comprises up to $65 \%$ of the $<2 \mu$ fraction. It is present in concentrations of up to $30 \%$ in some horizons in the Somali Basin cores, and also at Site 236.

The origin of palygorskite in these sediments is somewhat problematic. It may, in part, be an alteration product of volcanic rocks, as, although it is not particularly associated with volcanic debris, it is often associated with high concentrations of montmorillonite which itself could be a volcanic alteration product. However, it is absent from Site 238 where volcanic influences are strongest. Alternatively, the possibility that palygorskite may be a primary precipitate has been suggested by Bowles et al. (1971), who considered that it could form by the interaction of seawater with megnesium-rich hydrothermal solutions. Present data are inadequate for either of these hypotheses to be fully evaluated with regard to the Leg 24 palygorskite. Furthermore, some of the Gulf of Aden palygorskite could be detrital in origin. 


\section{Pyrite}

Pyrite is a common minor constituent in Leg 24 sediments and is usually concentrated in the $2-20 \mu$ fraction. It is present in all the Gulf of Aden and Somali Basin sites, indicating deposition under low redox conditions. As would be expected, it is almost absent from the more highly oxidized slowly accumulating sediments of the southern Indian Ocean, and was not detected at all at Site 238 where iron is largely present in the form of oxides.

\section{Chert}

Chert occurs fairly abundantly at Site 236 and 237, at the depths indicated in Table 4 . The age of the cherts ranges from lower Oligocene to lower Paleocene and the lithology of the enclosing sediments in nanno chalk. No detailed studies of the cherts have been made.

\section{Calcite}

Diagenetic calcite is abundant in the lower parts of the section at Site 237 where nanno-foram oozes are largely recrystallized to semilithified chalk rocks. No detailed studies of diagenetic calcites have been made of any Leg 24 materials.

\section{COLORS AND BIOGENIC, DEPOSITIONAL, AND DIAGENETIC STRUCTURES OF THE SEDIMENTS}

This section includes the description of primary and secondary sedimentary structures and the colors of the sediments, which, in many cases, demarcates structures which do not vary compositionally or texturally. The sedimentary structures and their relationship to one another are often disturbed by drilling. In particular, soft sediments are often disturbed. This must be considered when using the summary forms.

These forms will, however, give a gross picture of the distribution of sedimentary structure distribution in Leg 24 sediments.

\section{Colors}

The predominant colors of wet sediments found at Sites 231 to 238 are summarized in Figure 10, using the code numbers of the GSA rock color chart (Goddard et al., 1951).

On the basis of color distribution, the eight sites can be divided into three major provinces: Gulf of Aden, Somali Basin, and Central Indian Ocean around the Seychelles. Light olive-gray (5Y 5/2) and grayish to pale olive (10Y 4/2 to $10 \mathrm{Y} 6 / 2$ ) are the dominant hues at Sites 231,232 , and 233. All three have darker sediment at their bases. The gray to olive colors of the sediments at these three sites seem to be characteristic for the hemi-pelagic deposits of the Gulf of Aden, and they are closely related to the amount of terrigenous and shallow-water benthonic input. Very generalized lighter hues indicate high percentages of calcareous nannofossils and other pelagic organisms (high $\mathrm{CaCO}_{3}$ content), while darker ones usually indicate a higher clastic input. The end members, with transitions in between, are light olive-gray nanno ooze and nearly black horizons of terrigenous clay and silt.
Sites 234 and 235 in the Somali Basin are characterized by grayish, greenish, and bluish sediment colors which are closely related to the occurrence of abundant clay minerals. The uppermost core of Site 234, however, is moderate yellowish-brown, which, along with manganese nodules is indicative of an oxidizing environment.

The three sites around the Seychelles are a singular province with respect to sediment colors, which are mainly whitish or very light grayish-greenish to brownish in color. The whitish sediments are composed almost entirely of biogenic remains (mainly coccoliths, planktonic foraminifera, and various siliceous fossils) while the light grayish and greenish horizons indicate the presence of small quantities of clay minerals. Zeolitic clay at Site 236 is mainly gray to brown, while the micronodule-rich sediment is very light brownish and yellowish in color. Multicolored metalliferous sediments occur at the base of Site 238. They are discussed elsewhere in this chapter.

\section{Biogenic Sedimentary Structures}

Bioturbation at these eight sites is summarized in Figure 11 , and illustrated with some typical examples in Plate 5. Burrows are abundant at Sites 231, 232, 233, and some horizons of 234 , but are scarce in the sediments of the remaining sites. Burrow frequency at each site varies clearly with depth below the sediment surface.

It may be possible to use distribution and frequency patterns for an evaluation of former ecologic conditions. The presence of burrows indicate well-oxygenated conditions on the sea floor; lack of burrows indicates a deficiency of oxygen resulting in a scarcity of benthonic life. (See oxygen distribution in the modern Indian Ocean, Wyrtki, 1971; von Stackelberg, 1972.)

Two types of burrows can be distinguished in Figure 11: (1) those filled by sediment other than the surrounding sediment, differing either in color or texture; (2) those filled by the same kind of sediment as the surrounding sediment. Burrows of Type 1 are found mainly at Sites 231 and 232 and are scarce at Site 234. At all other sites, burrows usually contain the same sediment as the surrounding sediment and often they can be recognized only because of very thin pyrite coatings which appear as black spots or stripes in the sediments.

Several geometric forms of burrows or other evidence of biogenic activity have been found. These occur either in a tube form (horizontally oriented or vertically oriented [Plate 5, Figures 1, 2, 4], with or without internal structure, and may vary in size) or a planar form (these are always more or less horizontal in orientation [Plate 5, Figure 3]). The size of the tube-like burrows are dominated by types which are about $1 \mathrm{~cm}$ in diameter and another type which is a few millimeters in diameter.

Plate 5, Figure 5 shows a light sediment dotted with very dark spots (dark brown Fe oxides) resembling some kind of biogenic activity. However, it is not clear whether this is truly a remanent of bioturbation.

\section{Primary Depositional Structures}

Primary depositional structures are summarized in Figure 12 and illustrated in Plates 6-8. Although the 
TABLE 4

Chert Occurrences

\begin{tabular}{|c|c|c|c|}
\hline $\begin{array}{c}\text { Sample } \\
\text { (Interval in } \mathrm{cm} \text { ) }\end{array}$ & $\begin{array}{l}\text { Depth } \\
\text { (m) }\end{array}$ & Age & New Stratigraphy \\
\hline \multicolumn{4}{|l|}{ Site 236} \\
\hline $\begin{array}{l}27-2,10 \\
28-1,130 \\
29-1,50-140(+C C) \\
30-1,110-140(+C C) \\
30-2,50-60 \\
31-1,50-135 \\
31-2,30-80\end{array}$ & $\begin{array}{l}245 \\
254 \\
264 \\
273 \\
274 \\
283 \\
284\end{array}$ & $\begin{array}{l}\text { Upper Eocene } \\
\text { Middle Eocene } \\
\text { Lower Eocene } \\
\text { Lower Eocene } \\
\text { Lower Eocene } \\
\text { Lower Eocene } \\
\text { Lower Eocene }\end{array}$ & $\begin{array}{l}\text { Lower Oligocene } \\
\text { Upper Eocene } \\
\text { Lower Eocene } \\
\text { Lower Eocene } \\
\text { Lower Eocene } \\
\text { Lower Eocene } \\
\text { Lower Eocene }\end{array}$ \\
\hline \multicolumn{4}{|l|}{ Site 237} \\
\hline $\begin{array}{l}24-1,40^{\mathrm{a}} \\
32-1,120 \\
34-1,70-150 \\
35-1,70-140 \\
36-1,50-150 \\
37-1,115-150 \\
37-2,0-150 \\
38-1,0-150 \\
41-1,0-10 \\
41-2, \sim 140 \\
42-1,0-120 \\
43-1,0-150 \\
43-2,0-30 \\
46-2,130 \\
50-1,0-130 \\
58-1,110-140 \\
59-1,140-150 \\
51-1, \sim 50 \\
63-2, \sim 10-20 \\
64-2,140-150 \\
66-1, \sim 130\end{array}$ & $\begin{array}{l}216 \\
292 \\
311 \\
321 \\
330 \\
340 \\
341 \\
346 \\
383 \\
386 \\
393 \\
402 \\
404 \\
433 \\
469 \\
545 \\
555 \\
574 \\
613 \\
633 \\
669\end{array}$ & $\begin{array}{l}\text { Upper Eocene } \\
\text { Lower Eocene } \\
\text { Lower Eocene } \\
\text { Lower Eocene } \\
\text { Lower Eocene } \\
\text { Lower Eocene } \\
\text { Lower Eocene } \\
\text { Lower Eocene } \\
\text { Upper Paleocene }\end{array}$ & $\begin{array}{l}\text { Middle Eocene } \\
\text { Middle Eocene } \\
\text { M.-L. Eocene } \\
\text { M.-L. Eocene } \\
\text { M.-L. Eocene } \\
\text { Lower Eocene } \\
\text { Lower Eocene } \\
\text { L. Eocene-U. Paleocene } \\
\text { L. Eocene-U. Paleocene } \\
\text { Upper Paleocene } \\
\text { Upper Paleocene } \\
\text { Upper Paleocene } \\
\text { Upper Paleocene } \\
\text { U.-L. Paleocene }\end{array}$ \\
\hline
\end{tabular}

sediments of the western Indian Ocean and the Gulf of Aden are found to be rather homogeneous, different types of layering were found at all sites. Many times layering is expressed only by slightly changing hues, while differences in composition were neither macroscopically nor microscopically clearly discernible. Two types of bedding are shown in Figure 12. Those labeled "c" are structrues demarcated only by color change, those marked " $\mathrm{m}$ " are structures resulting from textural or compositional changes in the sediment. Often, however, these structures are distinguished by both characteristics. Based on these structures, the eight sites can be divided into three major provinces: the Gulf of Aden (Sites 231, 232, 233), the Somali Basin (Sites 234, 235), and the wide region around the Seychelles (Sites 236, 237, 238).

Frequent textural and compositional changes are typical for the three Gulf of Aden sites (Figures 12 and Plates 6 and 7). The textural changes show all transitions from very fine-grained nanno oozes to sand layers containing abundant benthonic fossils or clastic material. The compositional variation ranges from nearly pure nanno oozes (found at all three sites) to fossiliferous quartzitic sandstone (found at the base of Hole 232A). The occurrence of the sandstone and the sedimentary structures (cross-bedding, lamination, frequent occurrence of clastic horizons) in the unconsolidated sediments directly above it together with abundant benthonic fossils suggest that water depth was different during the time of deposition from today.

Volcanic ash layers consisting mostly of colorless glass are found at all three sites. They occur as sharp, thin horizons, indicative of very short events (see volcanogenics, this chapter).

The Somali Basin contains very fine-grained sediments. Bedding planes distinguished by textural changes are the exception. However, in both Sites 234 and 235, variations of color and composition were found, due mainly to changes in the calcium carbonate content. The coarse biogenic fraction of these sediments consists mostly of noncarbonate material (fish debris, sponge spicules, and various other siliceous fossils) and a very few foraminifera (dominated in many samples by benthics). Where they have been found, planktonic foraminifera fragments consist almost entirely of the solution-resistant parts of the shells (mainly keels, or heavily encrusted parts [Phleger et al., 1953; Berger and von Rad, 1972]). These components indicate that most of the calcium carbonate (presumably more than 95\%, Berger and von Rad, 1972) has been removed from the sediments due to solution. However, the surface sediments of Site 234 contain more $\mathrm{CaCO}_{3}$ than usual for the Somali Basin and indicate that today calcium carbonate dissolution is not as active as in former times. The surface sediments of this site consist of nanno oozes to nanno-rich clays, but the proportion of the noncarbonate 

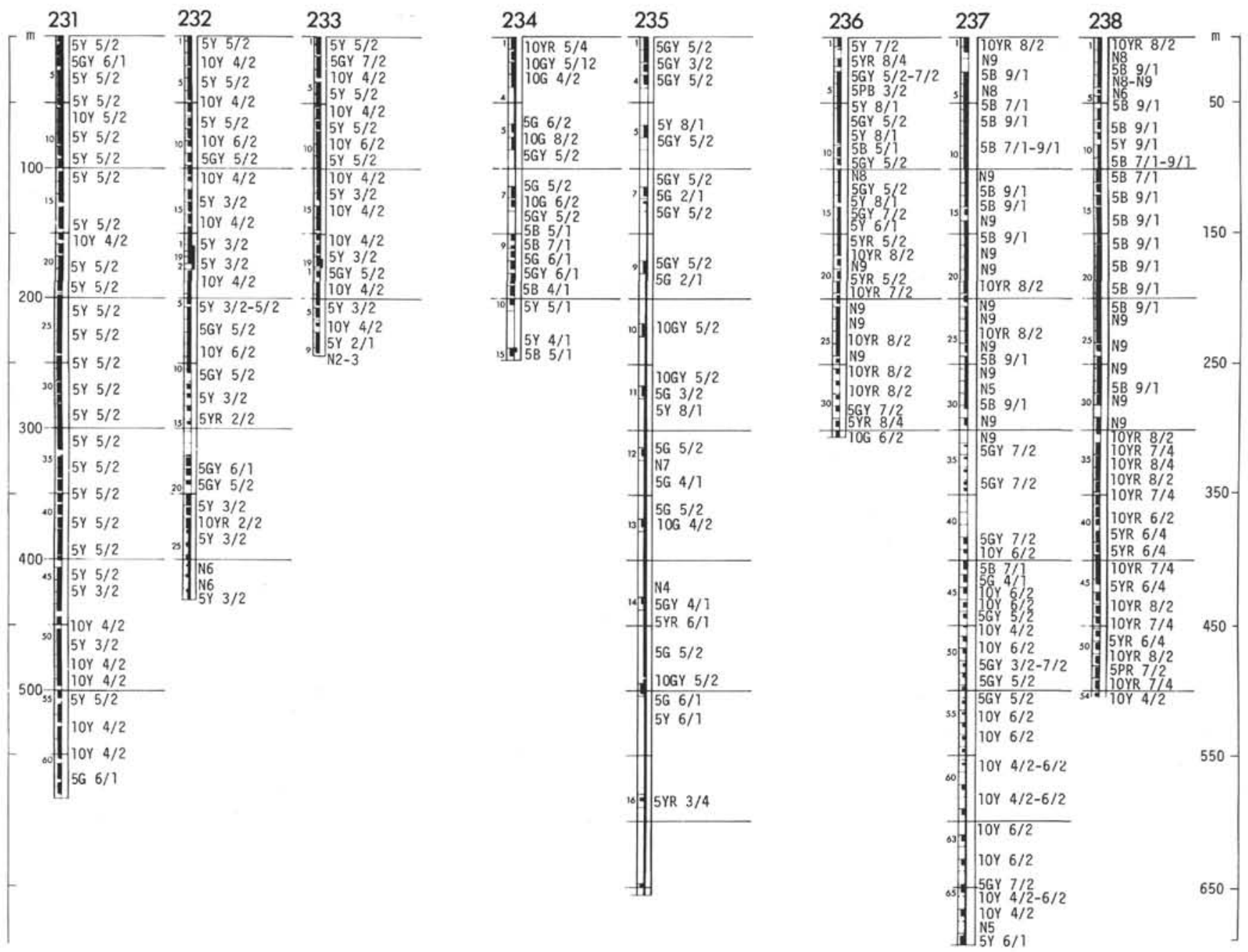

\begin{tabular}{|c|c|c|c|c|c|}
\hline Code & color & Code & color & Code & Color \\
\hline $\begin{array}{l}5 Y R \quad 2 / 2 \\
5 Y R \quad 3 / 4 \\
5 Y R \quad 5 / 2 \\
5 Y R \quad 6 / 1 \\
5 Y R \quad 6 / 4 \\
5 Y R \quad 8 / 4 \\
10 Y R \quad 2 / 2 \\
10 Y R \quad 5 / 4 \\
10 Y R \quad 6 / 2 \\
10 Y R \quad 7 / 2 \\
10 Y R 7 / 4 \\
10 Y R \quad 8 / 2 \\
5 Y 2 / 1 \\
5 Y 3 / 2 \text { and } 5 Y 4 / 1\end{array}$ & $\begin{array}{l}\text { Dusky brown } \\
\text { Moderate brown } \\
\text { Pale brown } \\
\text { Light brownish gray } \\
\text { Light brown } \\
\text { Moderate orange pink } \\
\text { Dusky yellowish brown } \\
\text { Moderate yellowish brown } \\
\text { Pale yellowish brown } \\
\text { Pale grayish orange } \\
\text { Grayish orange } \\
\text { Very pale orange } \\
\text { 01ive black } \\
\text { Olive gray }\end{array}$ & $\begin{array}{l}5 Y 5 / 1,5 Y 5 / 2, \\
5 Y 6 / 1 \\
5 Y 7 / 2 \text { and } 5 Y 8 / 1 \\
5 Y 9 / 1 \\
10 Y 4 / 2 \\
10 Y 5 / 2 \\
10 Y \quad 6 / 2 \\
5 G Y 3 / 2 \\
5 G Y 4 / 1 \text { and } 5 G 4 / 1 \\
5 G Y 5 / 2 \\
5 G Y \quad 6 / 1 \text { and } 5 G 6 / 1 \\
5 G Y \quad 6 / 2 \\
5 G Y 7 / 2 \\
10 G Y 5 / 2\end{array}$ & $\begin{array}{l}\text { Light olive gray } \\
\text { Yellowish gray } \\
\text { Grayish white } \\
\text { Grayish olive } \\
\text { Light olive } \\
\text { Pale ollive } \\
\text { Grayish olive green } \\
\text { Dark greenish gray } \\
\text { Dusky yellow green } \\
\text { Greenish gray } \\
\text { Moderate yellow green } \\
\text { Grayish yellow green } \\
\text { Grayish green }\end{array}$ & $\begin{array}{l}5 G 2 / 1 \\
5 G 3 / 2 \\
5 G 5 / 2 \text { and } 10 G 4 / 2 \\
5 G 6 / 2 \\
10 G 6 / 2 \\
10 G 8 / 2 \\
5 B \quad 4 / 1 \\
5 B 5 / 1 \\
5 B 7 / 1 \\
5 B 9 / 1 \\
5 P B \quad 3 / 2 \\
5 P R 7 / 2 \\
N 2-N 9\end{array}$ & $\begin{array}{l}\text { Greenish black } \\
\text { Dusky green } \\
\text { Grayish green } \\
\text { Hoderate green } \\
\text { Pale green } \\
\text { Very pale green } \\
\text { Dark bluish gray } \\
\text { Medium bluish gray } \\
\text { Light bluish gray } \\
\text { Bluish white } \\
\text { Dusky blue } \\
\text { Very pale red purples } \\
\text { Grayish black-white }\end{array}$ \\
\hline
\end{tabular}

Figure 10. Distribution of main colors at Sites 231 to 238 in the western Indian Ocean and Gulf of Aden.

biogenic components is considerably higher than in well-preserved calcareous deep-sea sediments.

The three sites around the Seychelles $(236,237,238)$ are characterized mainly by the major biogenic pelagic facies (with the exception of the lowermost part of 237) of low-latitude regions, with end members of nanno ooze, foram ooze, and rad ooze. However, transitions from one facies to the next have been found. Intercalations of one facies into another causes bedding, which is marked by textural and compositional changes and color variations (nanno and foram ooze being mostly whitish or very light colored, rad ooze is moderate brown). In contrast to the features found at Sites 234 and 235, these variations seem to be due to differences of production (Arrhenius, 1963) rather than preservation.

Macroscopically, most of these biogenic sediments look homogeneous at least within single horizons. This is true in terms of small-scale sedimentary structures as shown in Figure 13. This sample was taken from a homogeneouslooking nanno ooze, but thin section reveals bedding due to sorting on a small scale.

The lowermost part of Site 237 is an exception due to the presence of shallow-water-derived benthonic fossils (horizons of larger benthonic foraminifera, fragments of 


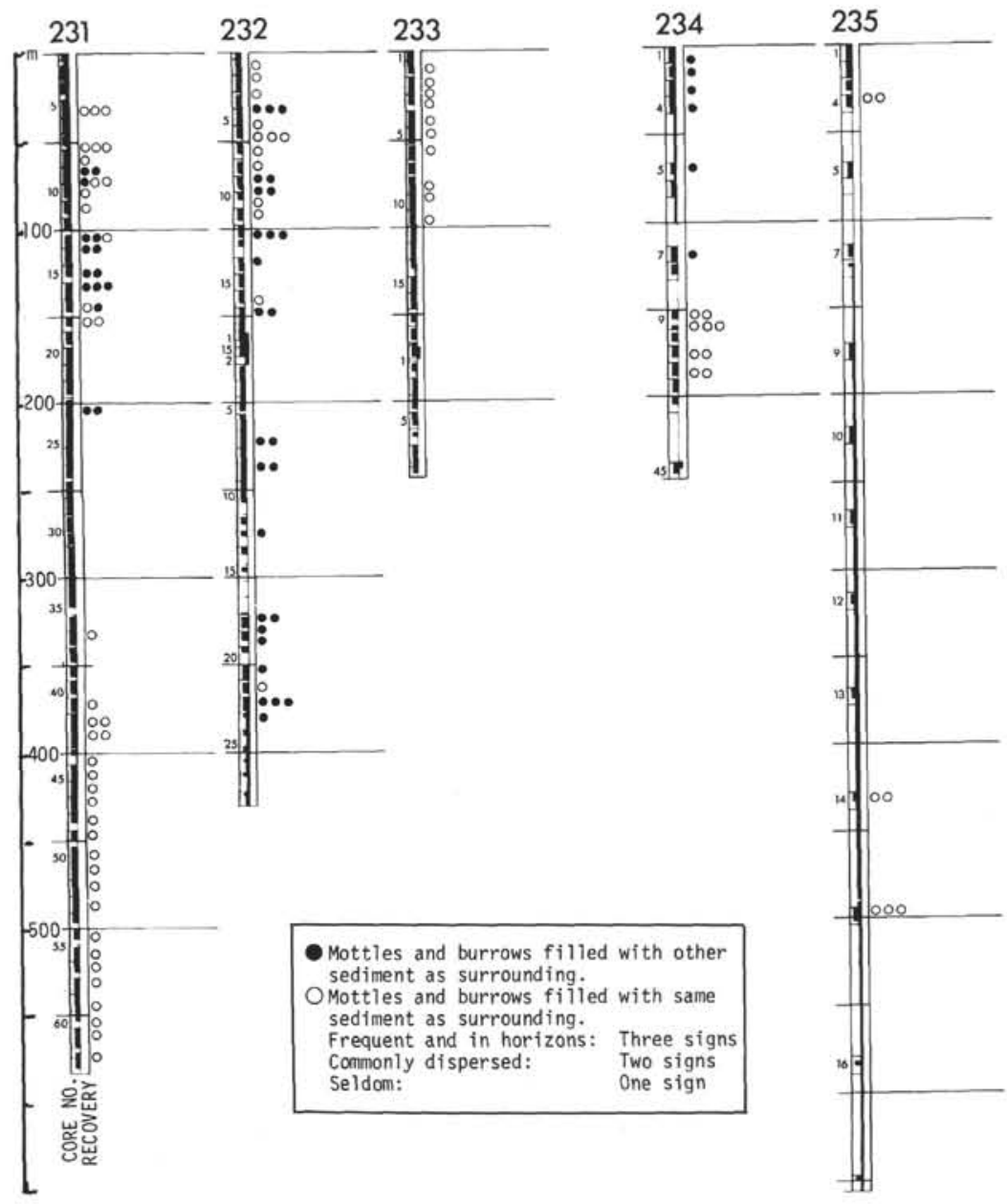

algal limestone) and of glauconite. In some of these horizons intensive lamination and lensing occur; all these features suggest former water depths, which were considerably more shallow than today $(1640 \mathrm{~m})$.

\section{Diagenetic Structures in the Sediments}

Chert horizons and layers in Eocene and Paleocene strata are the major diagenetic structures at Sites 236 and 237. All transitions from partly silicified limestone to light brownish to almost black chert (this type seen only in Paleocene sediments) were found. Evidence for the occurrence of Paleogene cherts has been found in all three major oceans (Calvert, 1971) as well as in many land sections; these sediments have been described from a number of DSDP sites (von Rad and Rosch, 1972). The cause of this world-wide chronostratigraphic consistent genesis of chert, which has been repeated several times since late Mesozoic times, is still in question.

Compaction and consolidation of the sediments also cause diagenetic sedimentary structures.

Manganese nodules (up to $6 \mathrm{~cm}$ in diameter) were found in the uppermost sections at Site 234 and a pyrite nodule (about $2 \mathrm{~cm}$ in diameter) in Core 13 at Site 235 .

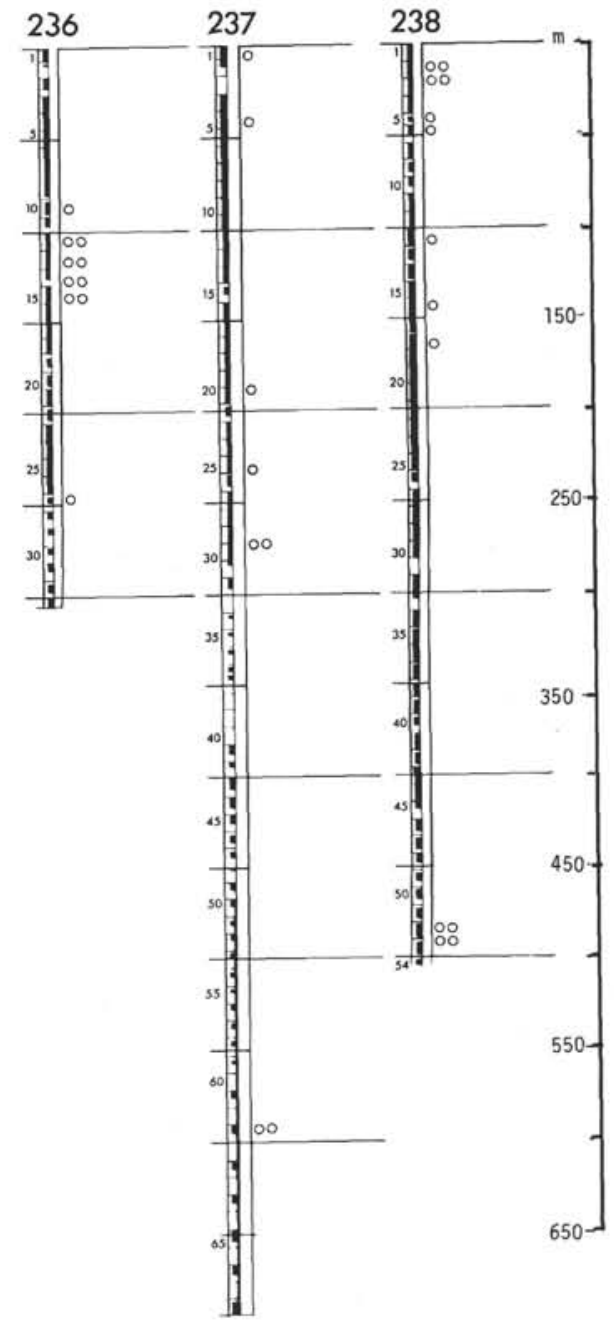

\section{SEDIMENTARY FACIES}

\section{Hemipelagic Sedimentary Facies}

The three sites in the Gulf of Aden contained sediments composed of remains of pelagic-living organisms (mainly nanno oozes). However, in a number of horizons the proportions of benthonic and clastic terrigenous components were much too high for normal pelagic deep-sea sediments (Plates 1 and 2). The holes in the Gulf of Aden also contain sediments composed entirely of land-derived material. It seemed reasonable, therefore, to treat the deposits found in these three holes separately under hemipelagic sedimentary facies.

Some very generalized distribution of main components in the different lithologic units is given for Site 231, based on smear-slide descriptions (Figure 14). Calcareous nannofossils are the most important component in all cores, even those directly above the basaltic basement. The distribution of sand-sized material indicates two lithologic units containing on the average much more coarse material than the other sediments. The lower maximum is clearly related to high proportions of noncalcareous clastic detrital material, the upper one to a greater input of large 

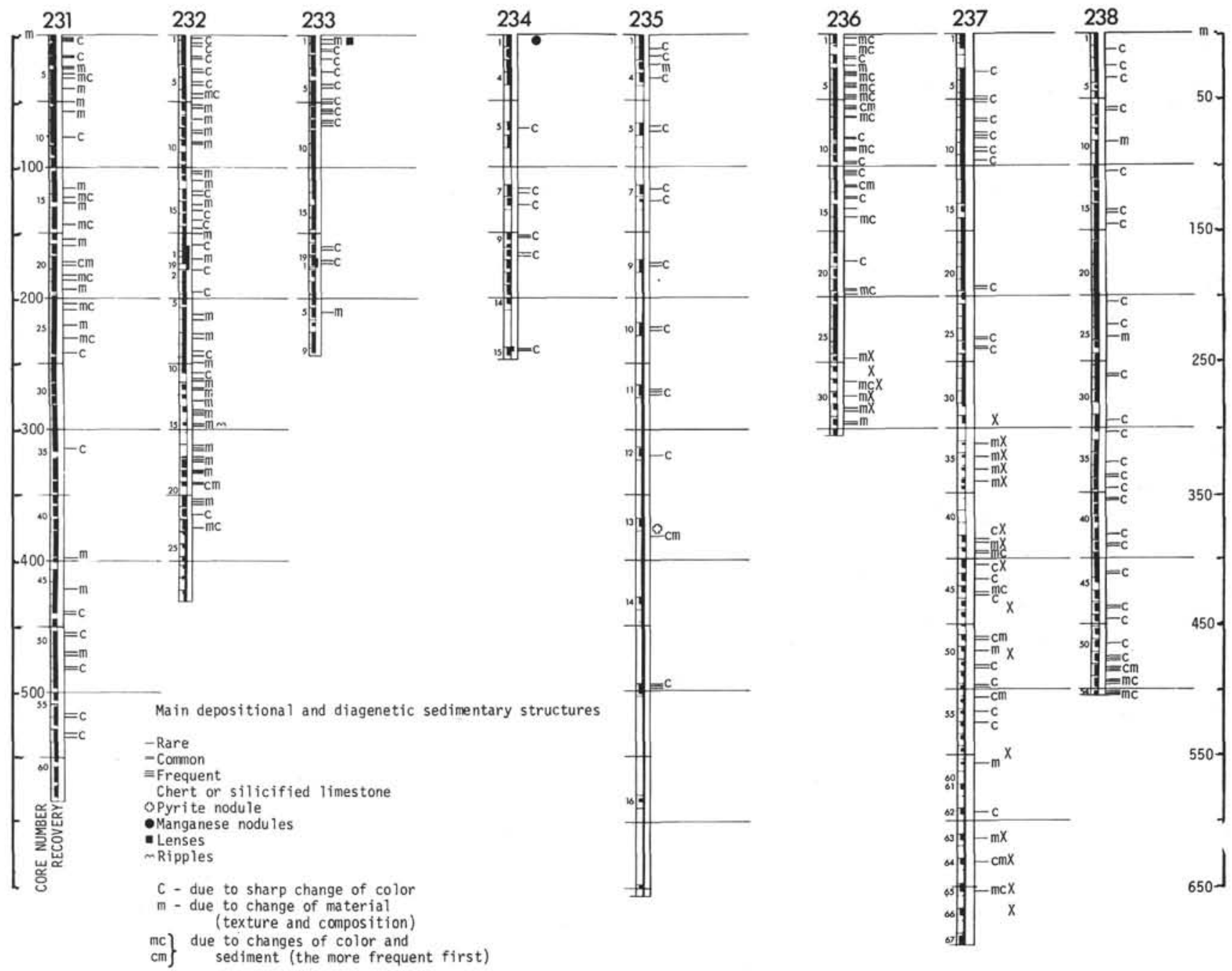

Figure 12. Distribution of main depositional and diagenetic sedimentary structures at Sites 231 to 238 .

benthonic components (bryozoans, molluscs, corals, foraminifera). These components are often not concentrated in horizons, but are found dispersed in the sediment. This, therefore causes difficulty in determining a sedimentation mechanism. These components are usually not found in deep-sea sediments, but are more typical of a shallow-water environment. In addition to these differences, the sediments of the Gulf of Aden have different colors and textural patterns and sedimentary structures are more complex than the other sites in the Indian Ocean. Bioturbation and sedimentary structures indicative of strong water movements are well correlated in the Gulf of Aden sites (Figures 11 and 12).

The sediments of the lowermost part of Site 237 contain a number of components derived from shallow water (Figure 15, algal limestone fragments and larger benthonic foraminifera). These very good shallow-water indicators occur mostly as enriched horizons and could therefore have been transported to deeper water, but the surrounding sediment suggests that is actually was deposited in much shallower water depths. This conclusion is based on the presence of frequent echinoderm debris, mollusc debris, and benthonic foraminifera.

\section{Biogenic Pelagic Sedimentary Facies}

Three major biogenic pelagic facies (nanno ooze, foram ooze, rad ooze) are represented in the Leg 24 sediments (the distribution of these major facies is summarized in Figure 2). However, these three facies are only end members with various transitional types (see smear-slide summaries in Appendix of this chapter).

\section{Nanno Ooze}

Nanno ooze is the most dominant sediment in the Indian Ocean. It is composed mainly of the calcareous remains of small marine planktonic plants living in the uppermost layer of the water column. Their Recent distribution in the Indian Ocean is not well known (Gaarder, 1971). Quantitatively, these tests are much more abundant than other components of deep-sea sediments, but they were not recognized until a few decades ago. Terms like "Globigerina 

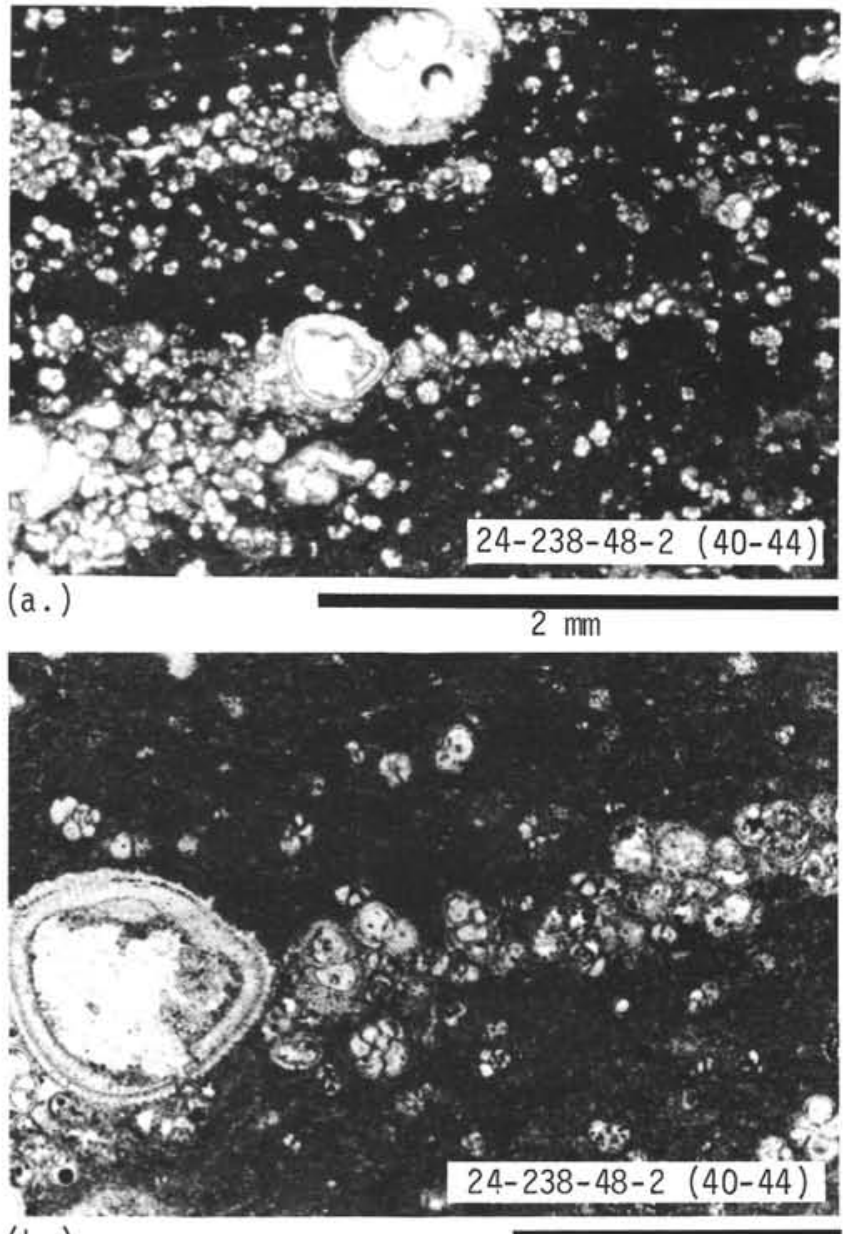

(b.)

$0.5 \mathrm{~mm}$

Figure 13. 24-238-48-2, 40-44 cm. (a). Micrograph of thin section revealing bedding planes indicated by horizons of small and large planktonic foraminiferal shells. The sediments looked homogeneous macroscopically. (b) Detail of (a).

ooze" and "Globigerina mud" should be re-evaluated, therefore, considering this recognition.

Nanno ooze is the dominant sediment in the Gulf of Aden sites and in the three sites around the Seychelles. The sediments of the Somali Basin sites are strongly affected by calcium carbonate dissolution, therefore only four of the six lithologic units at Site 234 contain sizable amounts of calcareous nannofossils. At Site 235, for the same reason, only two $f$ three lithologic units possess small proportions of carbonate. Nannofossils are an excellent stratigraphic tool. They show not only a detailed biostratigraphy, but are also easily recognized in reworked.

Redeposited discoasters were found at many Leg 24 sites. At Sites 231, 235, and 236, Eocene, Oligocene, and Miocene reworked specimens were mainly found; at Site 238 the reworked discoasters were predominantly Oligocene, Miocene, and Pliocene.

Nannofossils are generally well preserved at all sites with the exception of the Somali Basin sites where solution-resistant components are rarely preserved, but even these are strongly etched (Pimm et al., 1972).
The nanno ooze facies was found at all sites, and at sites which reach basaltic basement it was found directly above the basalt and occurred occasionally as inclusions in the crystalline basement (Plate 4). The sediments here are mostly recrystallized which caused some difficulties in dating the sediments.

\section{Foraminifera Ooze}

Foram ooze was found only in a few horizons at Sites $231,232,236,237$, and 238.

In all other sediments, foraminifera are usually quantitatively less important than coccoliths. They have occurred somewhat more frequently at Site 237 since lower Miocene and at Site 238 since middle Miocene.

With the exception of the Somali Basin sites, foram shells are usually rather well preserved. They are less well preserved in some horizons in the Gulf of Aden despite the relatively shallow-water depth. This might be related to the special pattern of calcium carbonate deposition and dissolution close to the continental margins (Thiede, in press).

\section{Radiolarian Ooze}

Rad ooze horizons are scarce in the Leg 24 sediments (Pleistocene or Site 236), but Radiolaria occur in small proportions in the sediments of all sites. Rad ooze is the sedimentary facies typical for the tropical high productive zone of the oceans (Sverdrup et al., 1942).

\section{Basal Metalliferous Sediments}

Basal metalliferous sediments similar to those forming on active oceanic ridges are common over much of the Pacific and Atlantic oceans (von der Borch and Rex, 1970; Bostrom, 1970; von der Borch et al., 1971; Cronan et al., 1972). Drilling in the vicinity of the Carlsberg and Central Indian ridges on Leg 24 indicates that similar deposits also occur in the Indian Ocean. Basal sediments from Sites 236 and 238 contain higher than average concentrations of iron. In addition, slightly ferruginous sediments occur at Site 235 .

The basal sediments from Site 236 consist of Paleocene or Eocene nannofossil clayey ooze, containing a layer, a few $\mathrm{cm}$ thick, of yellow-green ferruginous clay with approximately $23 \% \mathrm{Fe}$. Calcium carbonate is low in this layer. This was the only ferruginous sediment encountered at Site 236 and occurred approximately $40 \mathrm{~cm}$ above the basalt. In contrast, the basal sediments from Site 238, which are Oligocene in age, include several iron-rich layers, but none containing more than about $10 \% \mathrm{Fe}$ on a carbonate-free basis. The sediments consist of clays and indurated carbonate oozes, containing abundant globules of amorphous iron oxides and scattered volcanic debris. Montmorillonite occurs in concentrations of up to $64 \%$ of bulk samples, plagioclase up to $30 \%$, phillipsite up to $35 \%$, and alkali feldspar up to $15 \%$. The lowermost sediments obtained from Site 235 contain approximately $8 \% \mathrm{Fe}$ and occur at a depth of 580.7 meters. However, these sediments are not actually at the base of the section, as Site 235 was discontinuously cored to basement at a depth of more than 646 meters. Whether the iron-rich sediments extend to basement is not known. 


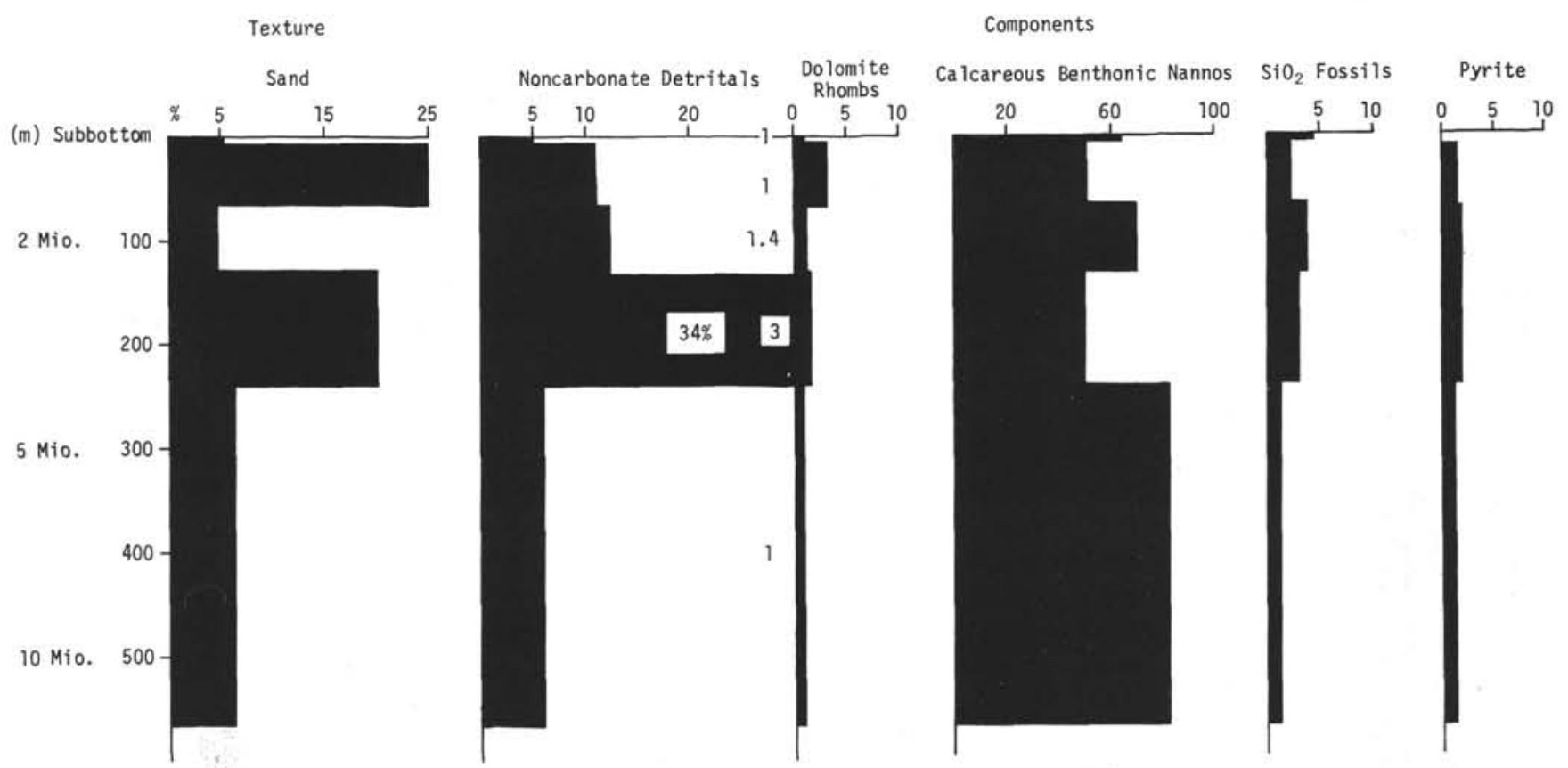

Figure 14. Main sedimentary components of Site 231 (based on smear-slide descriptions).

The origin of iron-rich basal metalliferous sediments has been the subject of considerable discussion. However, most workers consider at least the iron in these deposits to be hydrothermal in origin (Corliss, 1971; Cronan, 1973). The iron values at Site 238 are lower than the average for East Pacific Rise (EPR) sediments (Cronan et al., 1972), but are higher than some individual EPR values. However, the high iron value at Site 236 is very similar to some of the highest values in EPR sediments. If iron concentrations in basal metalliferous sediments reflect the activity of the ridges on which they occur (Cronan, in press), the present data would suggest that the Carlsberg Ridge at the time of deposition of the basal sediments at Site 236 was similar in activity to the EPR at the present time, and was more active than the Central Indian Ridge at the time the basal sediments at Site 238 were deposited. Obviously, more data are needed before these speculations can be substantiated.

\section{ACKNOWLEDGMENTS}

J. Thiede gratefully acknowledges the help of Dr. F. Werner (University of Kiel/Germany) and his coworkers, who overtook the difficult task of preparing the soft sediment samples for thin sections. I also thank Woods Hole Oceanographic Institution for putting the CHAIN 100 samples at my disposal.

\section{REFERENCES}

Arrhenius, G., 1963. Pelagic sediments. In Hill, M. N. (Ed.), The Sea: vol. 3, New York (Interscience), p. 655-727. Azzaroli, A., 1958. L'Oligocene e il Miocene della Somaliá: Italica, v. 52, p. 1-142.

Berger, W. H. and von Rad, U., 1972. Cretaceous and Cenozoic sediments from the Atlantic Ocean. In Hayes, D. E., Pimm, A. C. et al., Initial Reports of the Deep Sea Drilling Project, Volume 14: Washington (U. S. Government Printing Office), p. 787-954.
Beydoun, Z. R., 1970. A discussion on the structure and evolution of the Red Sea and the nature of the Red Sea, Gulf of Aden and Ethiopian Rift: Phil. Trans. Roy. Soc. London, Series A, v. 267, p. 2-292.

Böstrom, K., 1970. Geochemical evidence for sea floor spreading in the south Atlantic: Nature, v. 227, p.1041 .

Bryson, R., 1968. A climatologist views weather satellites: Paper presented at NAS-ERC Colloq., 27 April 1968.

Calvert, S. E., 1971. Nature of silica phases in deep sea cherts of the North Atlantic: Nature, v. 234, p. 133-134.

Challis, G. A., 1962. Mineralogy of selected North Island pumices and ash showers. In Wellman, H. W. (Ed.), Holocene of the North Island of New Zealand: A coastal reconnaissance: Trans. Roy. Soc. New Zealand, Geol., v. 1 , no. 5 , p. $90-99$.

Church, T. M., 1970. Marine barite. Unpublished Ph.D. thesis, University of California, San Diego.

Corliss, J., 1971. The origin of metal-bearing submarine hydrothermal solutions in J. Geophys. Res. v. 76, p. 8128-8138.

Cronan, D. S., in press. Authigenic minerals in deep sea sediments. In Goldberg, E. D. (Ed.), The Sea, vol. 5: New York (Interscience).

Cronan, D. S. et al., 1972. Iron rich basal sediments from the eastern equatorial Pacific, Leg 16, Deep Sea Drilling Project: Science, v. 175, p. 61-63.

Dietz, R. S., 1942. Clay mineral in recent marine sediment: Am. Mineral, v. 27, p. 219.

Einsele, G. and Werner, F., 1972. Sedimentary processes at the entrance Gulf of Aden/Red Sea: Geol. Inst. Univ. Kiel. Unpublished.

Gaarder, K. R., 1971. Comments on the distribution of Coccolithophorids in the oceans. In Funnell,B. M. and Riedel, W. R. (Eds.), The micropaleontology of oceans: Cambridge (Cambridge University Press), p. 97-103.

Goddard, E. N. et al., 1951. Rock color chart: Washington (Geol. Soc. Am.).

Goldberg, E. D. and Arrhenius, G., 1958. Chemistry of Pacific pelagic sediments: Geochim. Cosmochim. Acta., v. 13 , p. $153-212$. 


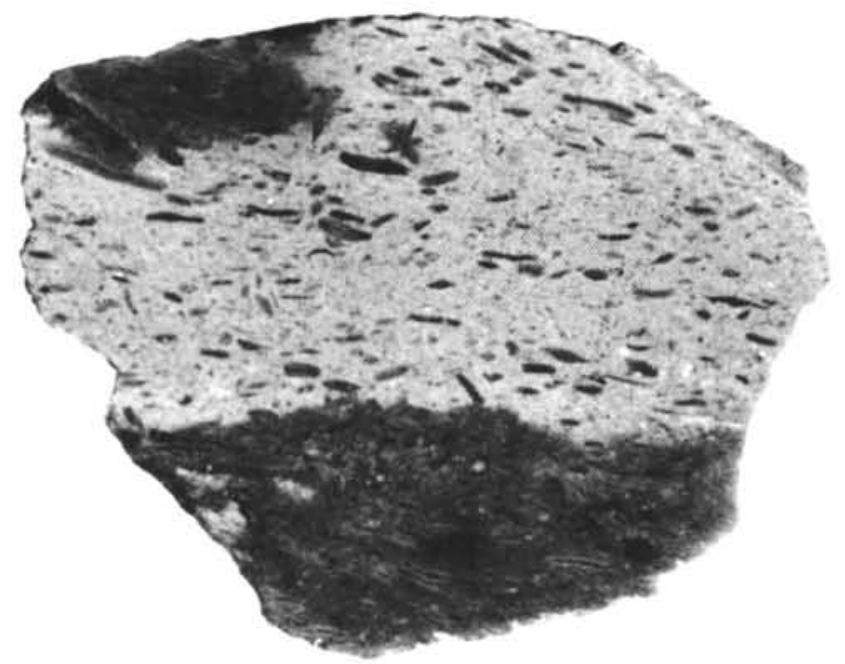

(a.)

$24-237-41-2-140$

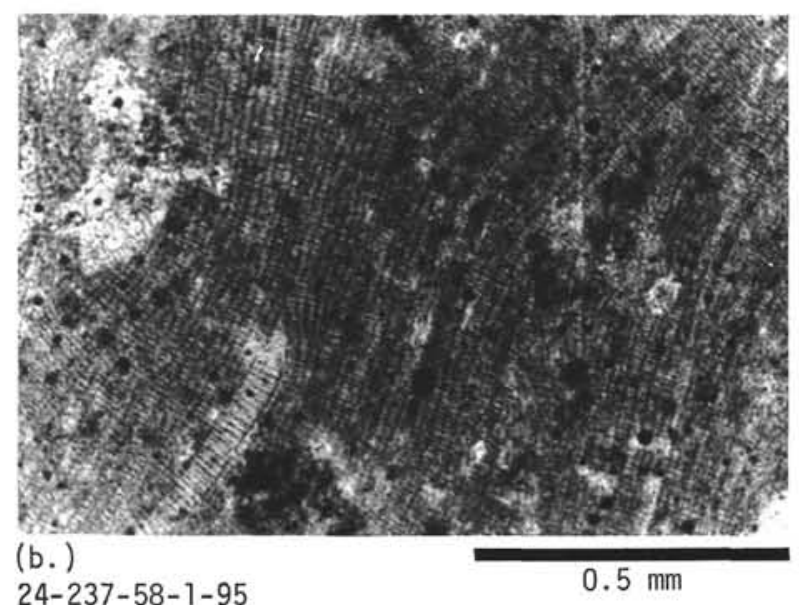

Figure 15. (a) 24-237-41-2, $140 \mathrm{~cm}$. Polished section. Silicified limestone (light part) and chert (dark part) originally mainly composed of the larger benthic foraminifera Discocyclina. Horizon containing these foraminifera is less than $10 \mathrm{~cm}$ thick.

(b) 24-237-58-1, $95 \mathrm{~cm}$. Thin section. Algal limestone fragment.

Goldberg, E. D. and Griffin, J. J., 1970. The sediments of the northern Indian Ocean: Deep-Sea Res., v. 17, p. 513-537.

Heezen, B. C., Nesteroff, W. D., Oberlin, A. and Sabatier, M. G., 1965. Découvert d'attapulgite dans le sediments profonds du Golfe d'Aden et de la Mer Rouge: Comp. Rend. Som. Soc. Geol. France, v. 260, p. 5819.

Hollister, C. D., Ewing, J. I. et al., 1972. Initial Reports of the Deep Sea Drilling Project, Volume 11: Washington (U. S. Government Printing Office).

Krumbein, W.C. and Pettijohn, F. J., 1938. Manual of sedimentary petrography: New York (Appleton-Century), $549 \mathrm{p}$.

Lowell, J. D. and Genik, G. J., 1972. Sea-floor spreading and structural evolution of southern Red Sea: Am. Assoc. Petrol. Geol. Bull., v. 56, p. 247-259.

Müller, G., 1961. Palygorskite und sepiolith in tertiären und Quaternären Sediment von Hadramawt (S. Arabien): Neues J. Miner., v. 97, p. 275-288.

Phleger, F. B., Parker, F. L. and Peirson, J. F., 1953. North Atlantic foraminifera: Rept. Swed. Deep-Sea Exped., v. 7 , no. 1, p. 1-122.

Pimm, A. C., Burroughs, R. H. and Bunce, E. T., 1972. Oligocene sediments near Chain Ridge, northwest Indian Ocean: structural implications: Marine Geol., v. 13, no. 1, p. M14-18.

Sverdrup, H. U., Johnson, M. W. and Fleming, R. H., 1942. The oceans: Englewood Cliffs (Prentice Hall).

Thiede, J., in press. Planktonic foraminifera in hemipelagic sediments: Shell Preservation off Portugal and Morocco: Geol. Soc. Am. Bull.

Vallier, T. L., 1970. The mineralogy of some turbidite sands from sites 32 and 35 . In McManus, . . . et al., Initial Reports of the Deep Sea Drilling Project, Volume 5: Washington (U. S. Government Printing Office), p. 535-539.

Van Der Lingen, G. J., 1968. Volcanic ash in the Makara Basin (Upper Miocene), Hawke's Bay, New Zealand: New Zealand J. Geol. Geophys., v. 11, no. 3, p. 693-705.

von der Borch, C. C. and Rex, R. W., 1970. Amorphous iron oxide precipitation in sediments cored during Leg 5, Deep Sea Drilling Project. In McManus, ... et al., Initial Reports of the Deep Sea Drilling Project, Volume 5: Washington (U.S. Government Printing Office)p.541-544.

von der Borch, C. C., Nesteroff, W. D. and Galehouse, J. S., 1971. Iron-rich sediments cored during Leg 8 of the Deep Sea Drilling Project. In Tracey, J. I. et al., Initial Reports of the Deep Sea Drilling Project, Volume 8: Washington (U. S. Government Printing Office) p.829-833.

von Rad, U. and Rösch, H., 1972. Mineralogie and origin of clay minerals, silica and authigenic silicates in Leg 14 sediments. In Hayes, D. E., Pimm, A. C. et al., Initial Reports of the Deep Sea Drilling Project, Volume 14: Washington(U. S.Government Printing Office) p.727-751.

von Stackelberg, U., 1972. Faziesverteilung in Sedimenten des indisch-pakistanischen Kontinental-randes (Arabischen Meer).“"Meteor" Forsch.-Ergebn., v. C9, p. 1-73.

Williams, et al., 1954. Petrography - an introduction to the study of rocks in thin sections. Freeman \& Co., San Francisco.

Wooster, W. S., Schaefer, M. B. and Robinson, M. K., 1967. Atlas of the Arabian Sea for fishery oceanography: Instit. Mar. Res. Ref. 67-12. University of California, San Diego. Unpublished.

Wyrtki, K., 1971. Oceanographic atlas of the international Indian Ocean Expedition: Washington (National Science Foundation). 



\section{PLATE 1}

Sediments in the Gulf of Aden

Figure $1 \quad 24-231-3-4,120 \mathrm{~cm}$. Smear slide. Sediment is mainly composed of clastic terrigenous grains and test of foraminifera (both planktonic and benthonic).

Figure $2 \quad 24-231-3-4,120 \mathrm{~cm}$. Smear slide, same as shown in Figure 1. Foraminifera are sometimes filled with pyrite, many times fragmented. Dolomite rhombs are typical components of the Gulf of Aden sediments.

Figure $3 \quad 24-231-20-1,31 \mathrm{~cm}$. Smear slide. Volcanic ash which is almost entirely composed of colorless glass.

Figure $4 \quad 24-231-35-5,100 \mathrm{~cm}$. Smear slide. Nanno ooze characterized by typical discoasters.

Figure $5 \quad 23-232 \mathrm{~A}-27,1 \mathrm{~cm}$. Thin section. Quartzitic sandstone at the base of this site. Grains consist mostly of quartz, but note rounded basaltic fragment.

Figure 6

24-232A-27, $1 \mathrm{~cm}$. Thin section, same as shown in Figure 5. 
PLATE 1

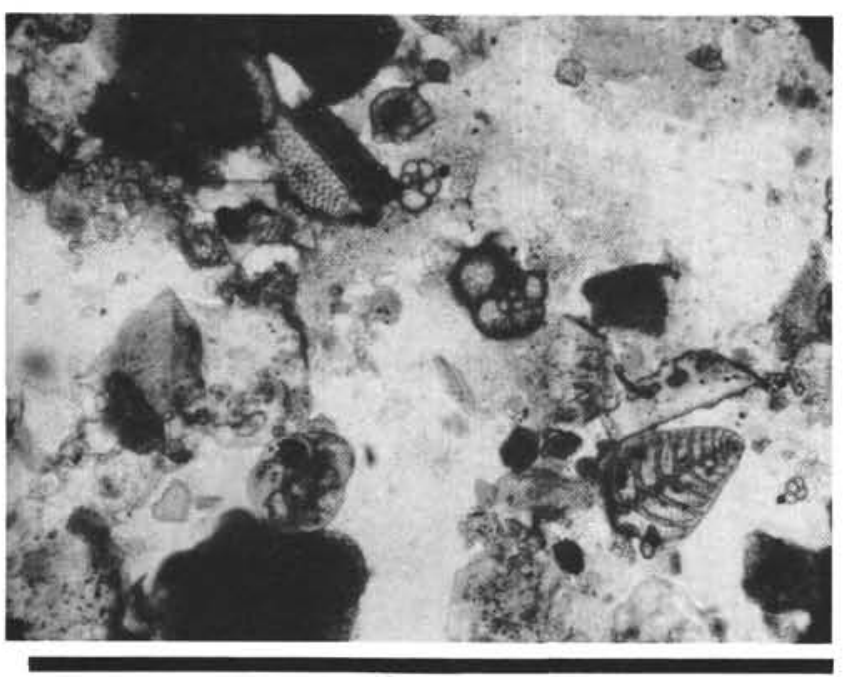

1. $231-3-4-120$

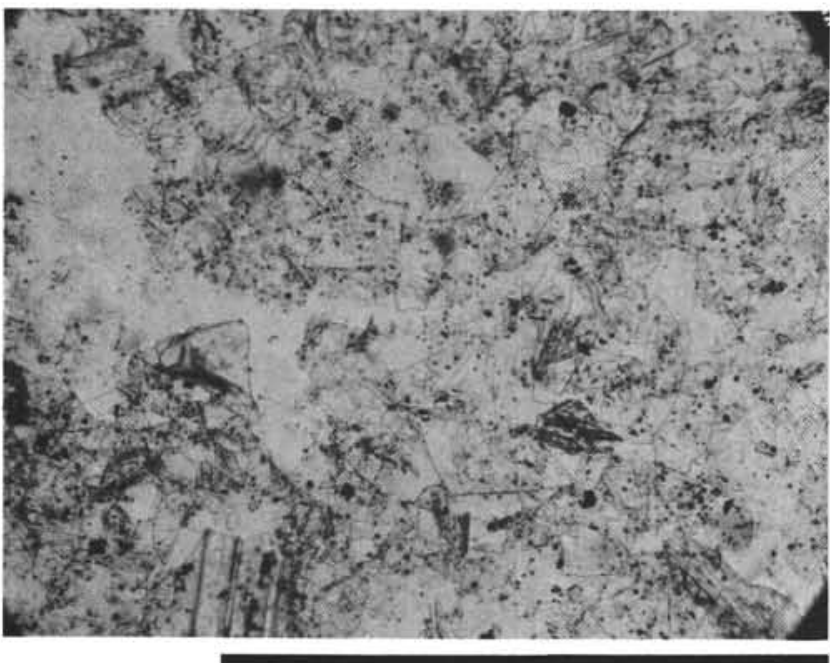

3. $231-20-2-31$

$0.3 \mathrm{~mm}$

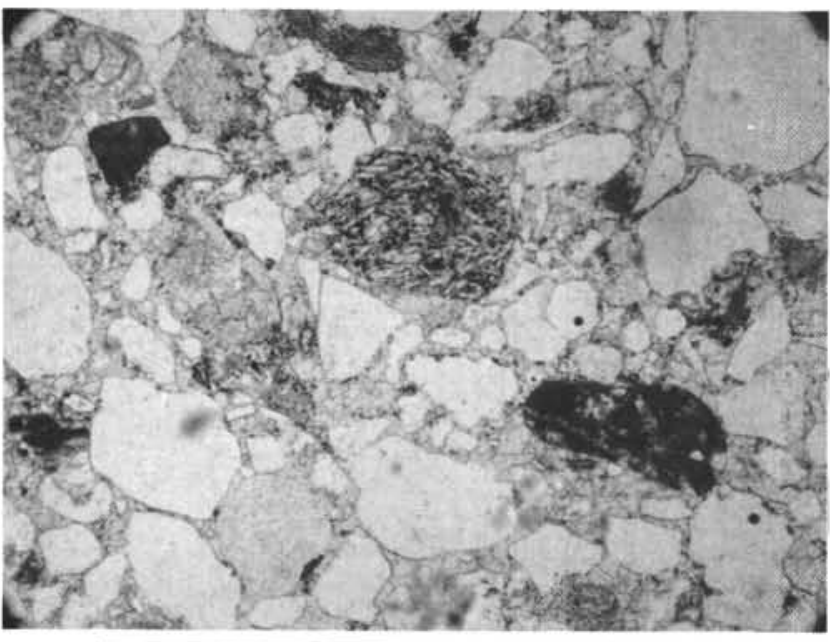

5. $232 A-27-1$

$1 \mathrm{~mm}$

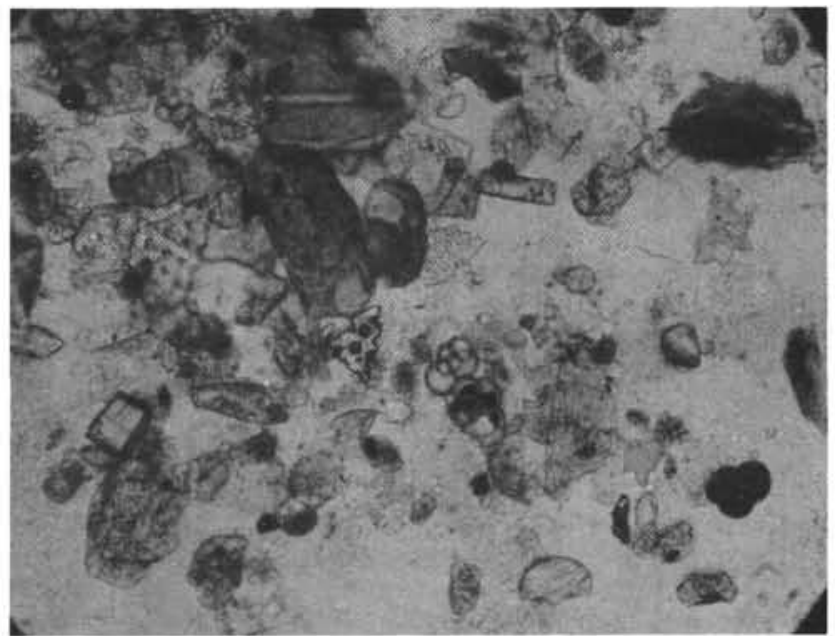

2. $231-3-4-120$

$0.5 \mathrm{~mm}$

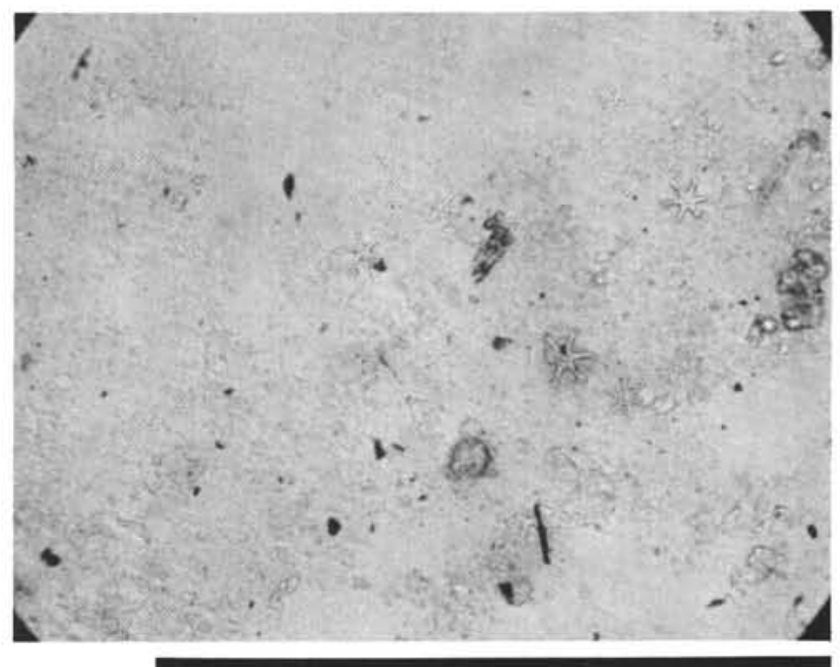

4. $231-35-5-100$

$0.05 \mathrm{~mm}$

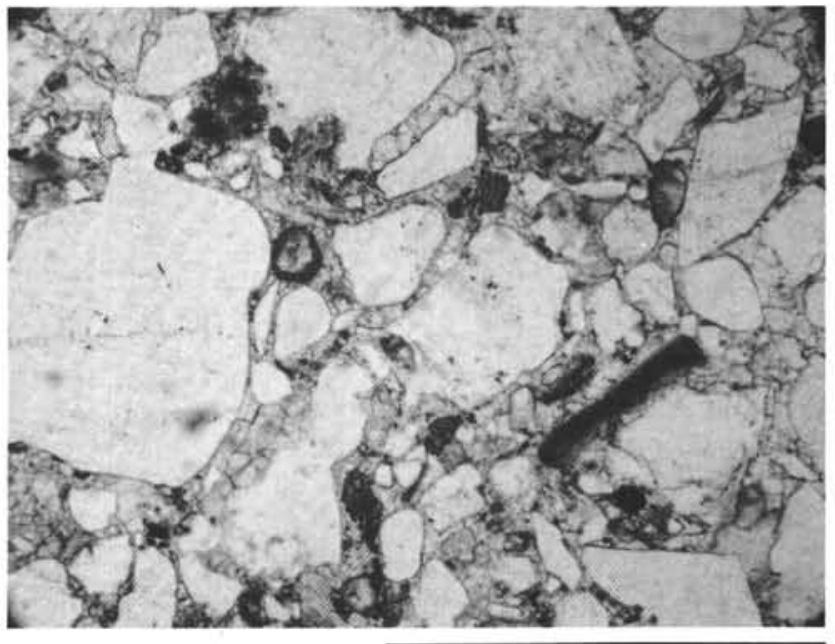

6. $232 A-27-1$

$0.5 \mathrm{~mm}$ 


\section{PLATE 2}

Sediments in the Gulf of Aden.

Figure 1

Figure 2

Figure 3

Figure 4

Figure 5

Figure 6
24-233-1-3, $90 \mathrm{~cm}$. Smear slide. Nanno ooze with high proportion of coarse clastic grains, foraminifera, Radiolaria, sponge spicules.

24-233-1-3, $90 \mathrm{~cm}$. Smear slide, same as Figure 1. Note isomorph dolomite rhombs with dark rounded core.

24-233-7-1, $180 \mathrm{~cm}$. Smear slide. Nanno ooze with high proportion of $\mathrm{SiO}_{2}$-fossils (radiolarians, silicoflagellates, diatoms).

24-233-10-4, $80 \mathrm{~cm}$. Smear slide. Note isomorph dolomite rhomb with dark core.

24-233-12-3, $80 \mathrm{~cm}$. Smear slide. Nanno ooze (note discoasters) with high proportions of rounded clastic grains, mainly quartz.

24-233-18-4, $90 \mathrm{~cm}$. Smear slide. Mainly $\mathrm{SiO}_{2}$-fossils (radiolarians frequently fragmented, diatoms, sponge spicules). 


\section{PLATE 2}

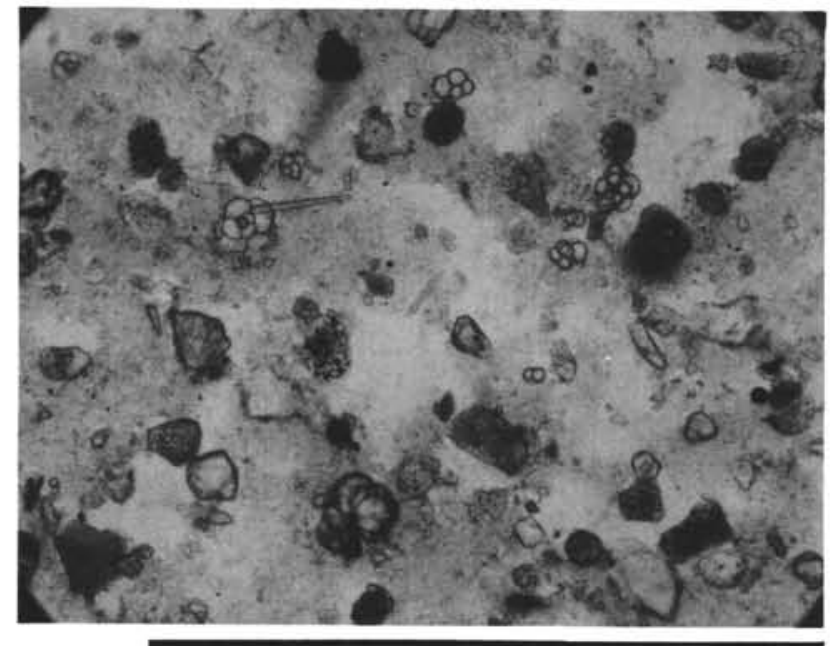

1. $233-1-3-90$

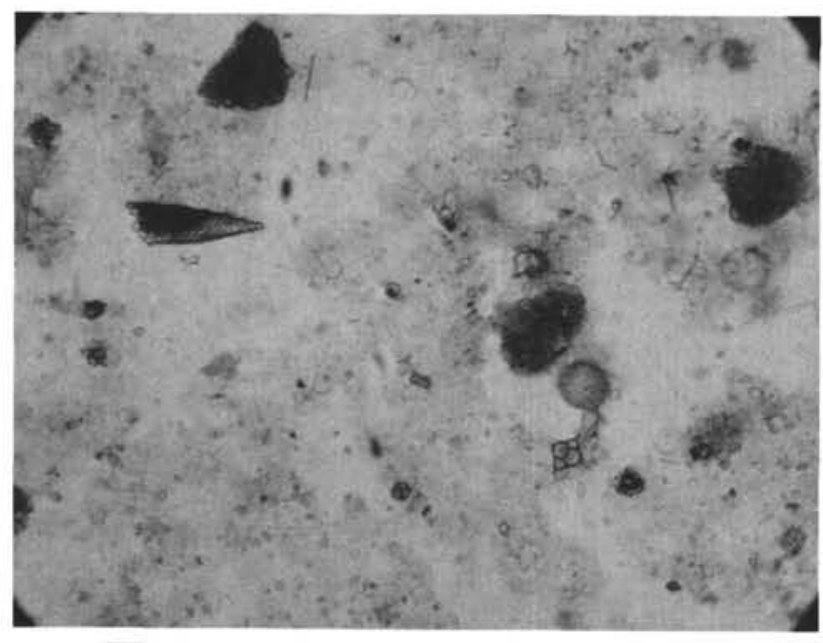

3. $233-7-1-180$

$0.1 \mathrm{~mm}$

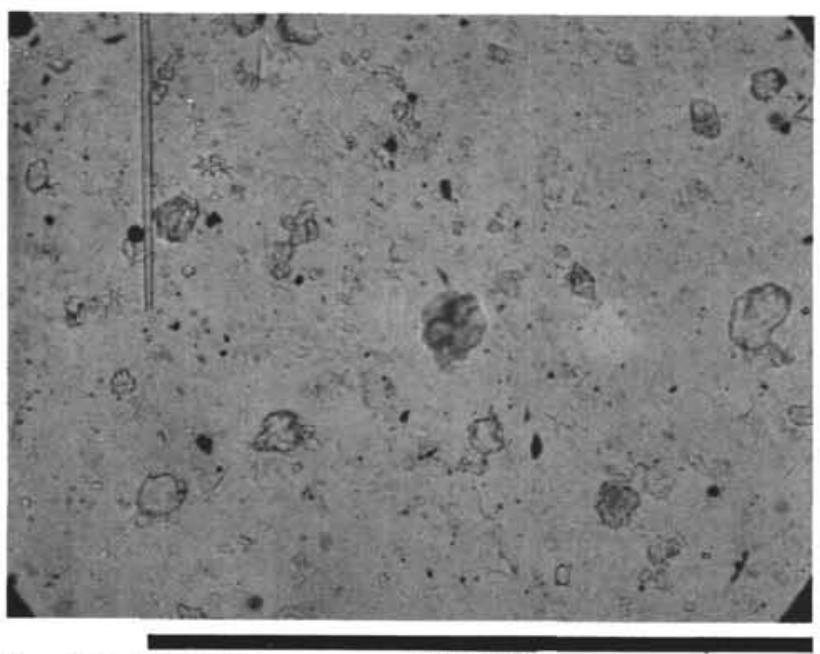

5. $233-12-3-80$

$0.05 \mathrm{~mm}$

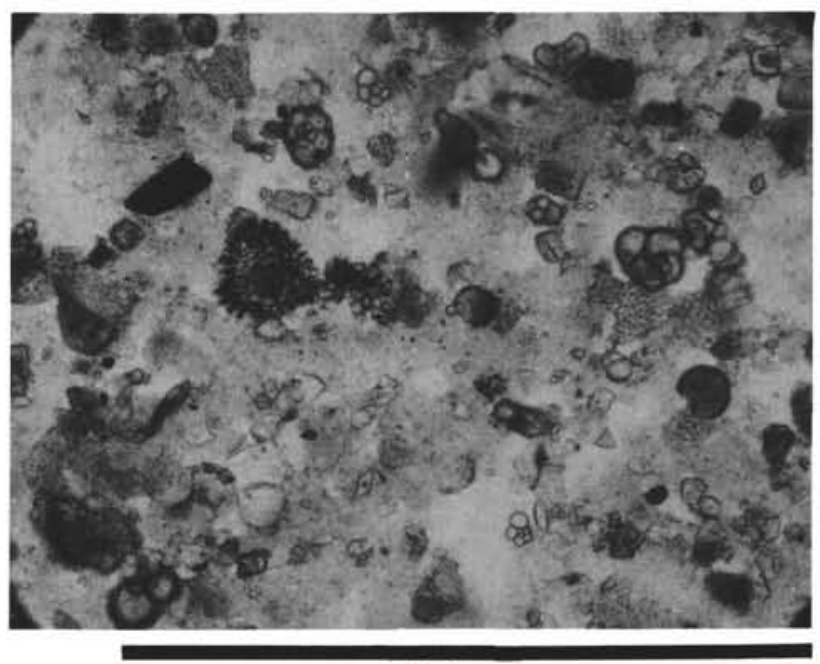

2. $233-7-3-90$

$0.3 \mathrm{~mm}$

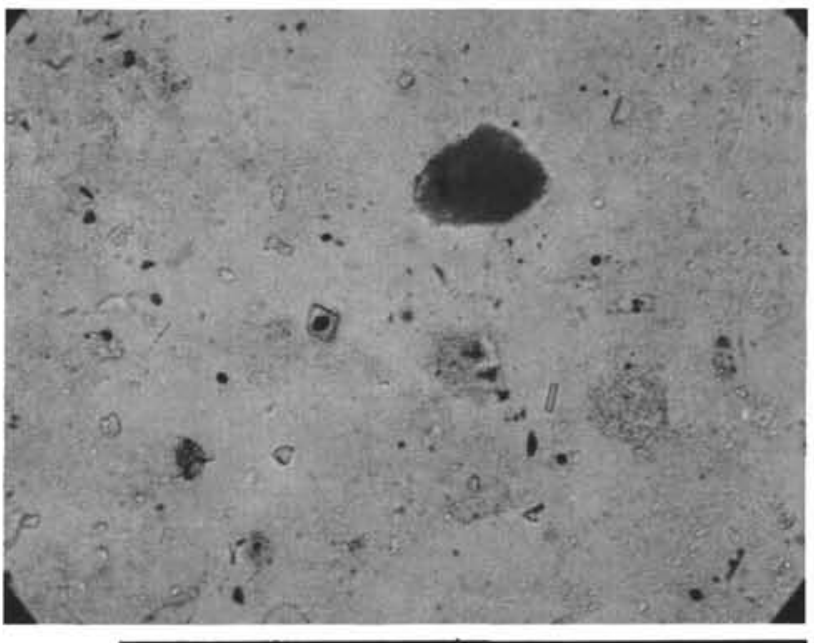

4. $233-10-4-80$

$0.1 \mathrm{~mm}$

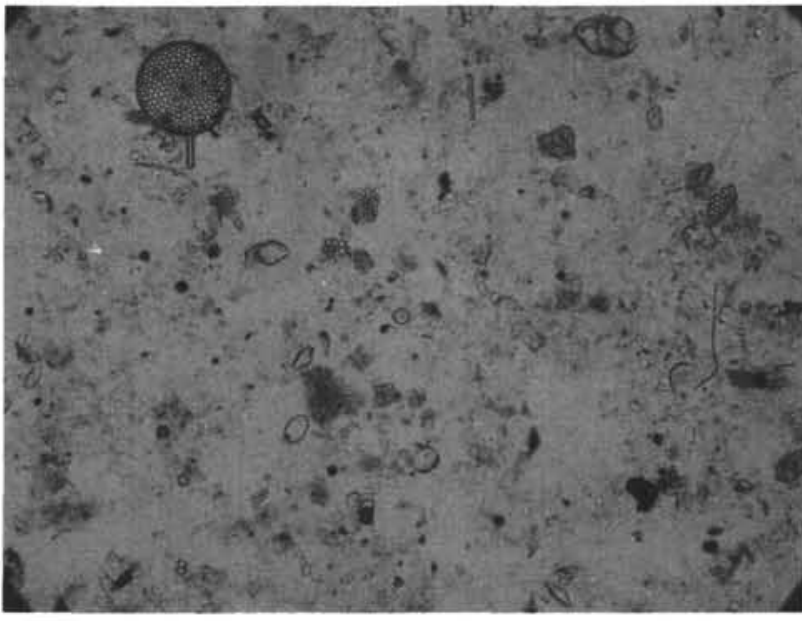

6. $233-18-4-90$ 


\section{PLATE 3}

Sediments in the Somali Basin. CHAIN 100 , Core $30 ; 04^{\circ} 27.7^{\prime} \mathrm{N}$, $51^{\circ} 08^{\prime} \mathrm{E} ; 5049$ meters, close to Site 234. CHAIN 100, Core 32; $03^{\circ} 14.2^{\prime} \mathrm{N}, 52^{\circ} 41.5^{\prime} \mathrm{E} ; 5123$ meters, close to Site 235.

Figure 1 CHAIN 100, Core 30, 0-7 cm. Smear slide. Main components of the sediment are $\mathrm{SiO}_{2}$-fossils (here diatoms, silicoflagellates, and sponge spicules). Few clastic grains.

Figure 2 CHAIN 100, Core 30, 0-7 cm. Smear slide. Detail of Figure 1.

Figure 3 CHAIN 100, Core 30, $110 \mathrm{~cm}$. Smear slide. Nanno ooze (matrix) and few coarser components (mainly foraminifera, Radiolaria, pteropods). Sediment seems to be displaced.

Figure 4 CHAIN 100, Core $30,110 \mathrm{~cm}$. Smear slide. Same as Figure 3.

Figure 5. CHAIN 100, Core $32,3-8 \mathrm{~cm}$. Smear slide. The sediment is mainly composed of $\mathrm{SiO}_{2}$-fossils, similar to Figure 1. 


\section{PLATE 3}
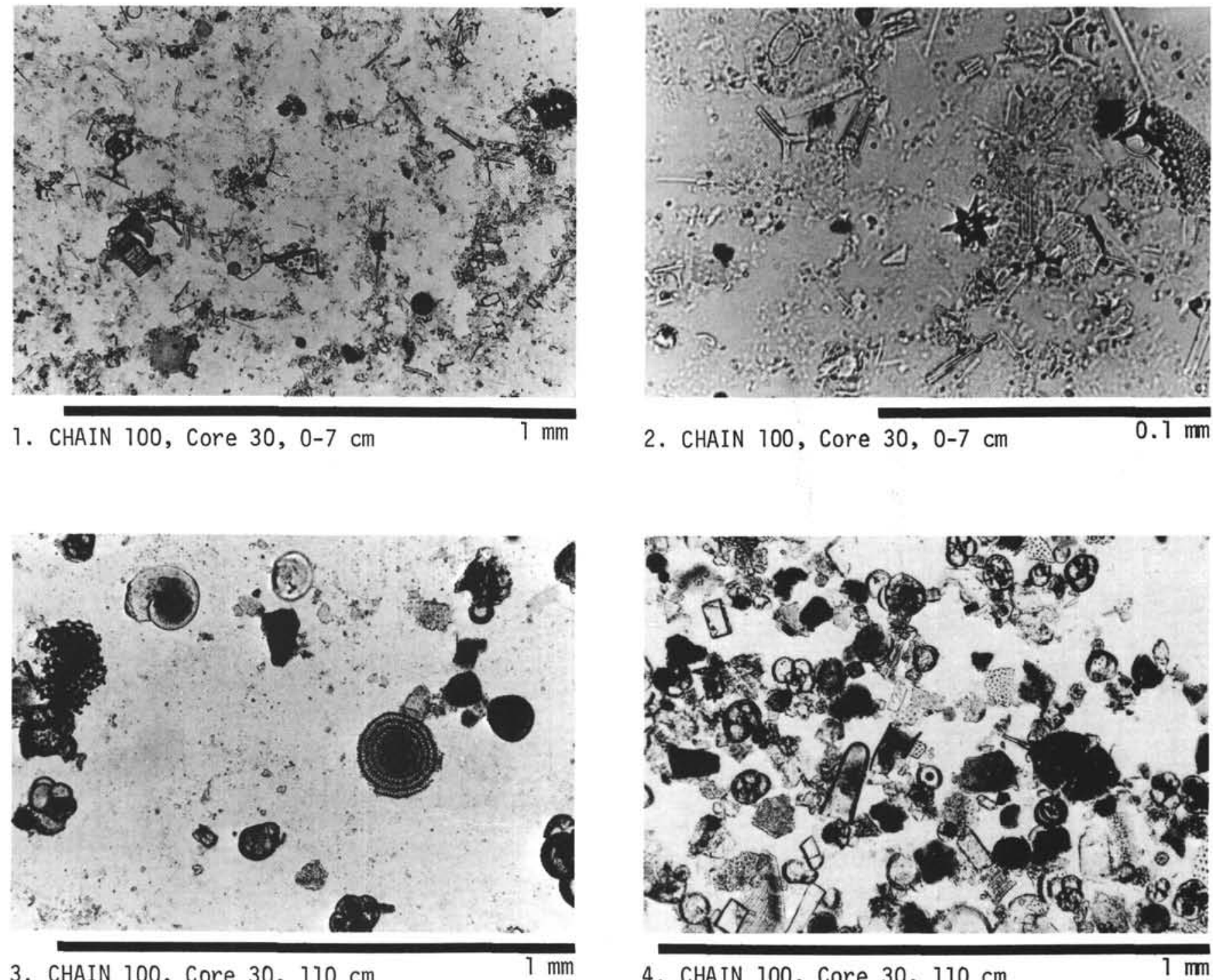

4. CHAIN 100 , Core $30,110 \mathrm{~cm}$ $1 \mathrm{~mm}$

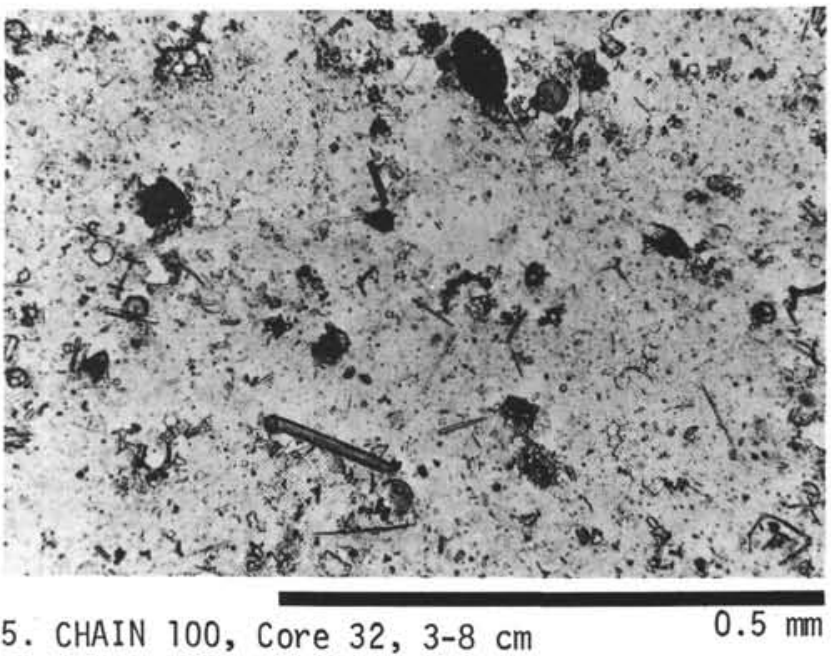




\section{PLATE 4}

Sediments around the Seychelles.

Figure 1

Figure 2

Figure 4

Figure 5
24-236-23-5, 27-30 cm. Thin section. Well-preserved Radiolaria in sediment rich also in other $\mathrm{SiO}_{2}$ components.

24-236-23-5, $27-30 \mathrm{~cm}$. Thin section. Large glass fragment. Same as Figure 1.

Sediment inclusions in basaltic basement

24-238-54-4, $6 \mathrm{~cm}$. Thin section. Note large fossil fragment and round sedimentary structures (burrow or fecal pellets?). Nanno ooze mainly recrystallized.

23-238-57-3, $6 \mathrm{~cm}$. Thin section. Recrystallized nanno ooze with larger fossils, mainly foraminifera.

24-238-58-4, $6 \mathrm{~cm}$. Thin section. Recrystallized nanno ooze. Note large gastropod and round sedimentary structures (cf. Figure 3). Lower part of thin section consists of vitreous randzone of basalt. 
PLATE 4

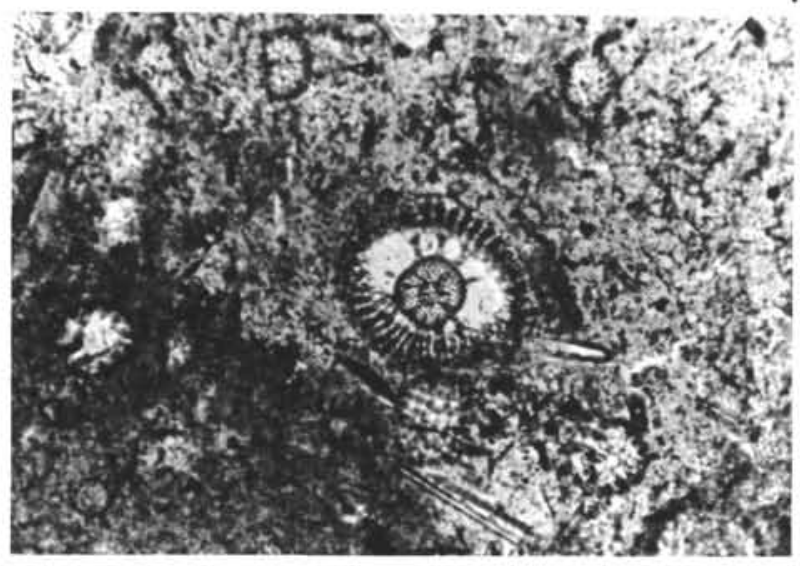

1. $236-23-5(27-30)$

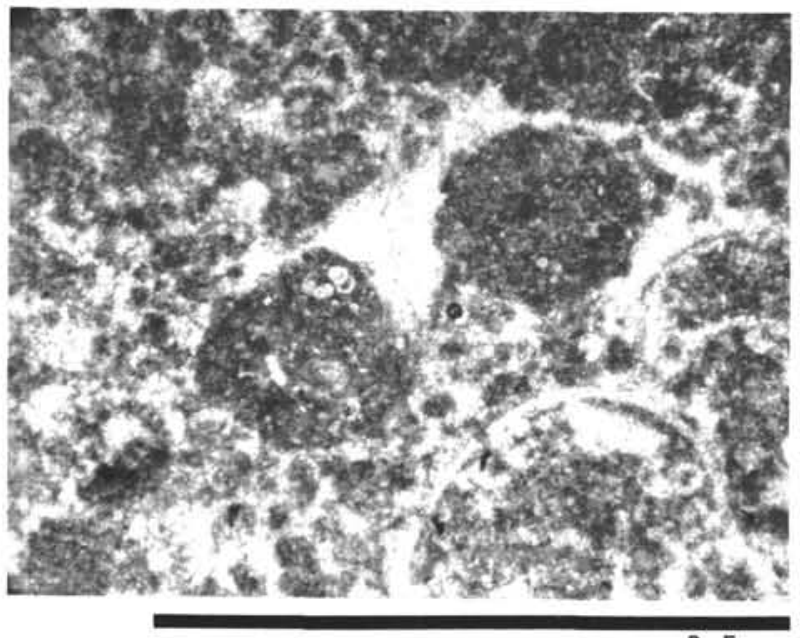

3. $238-54-4-6$
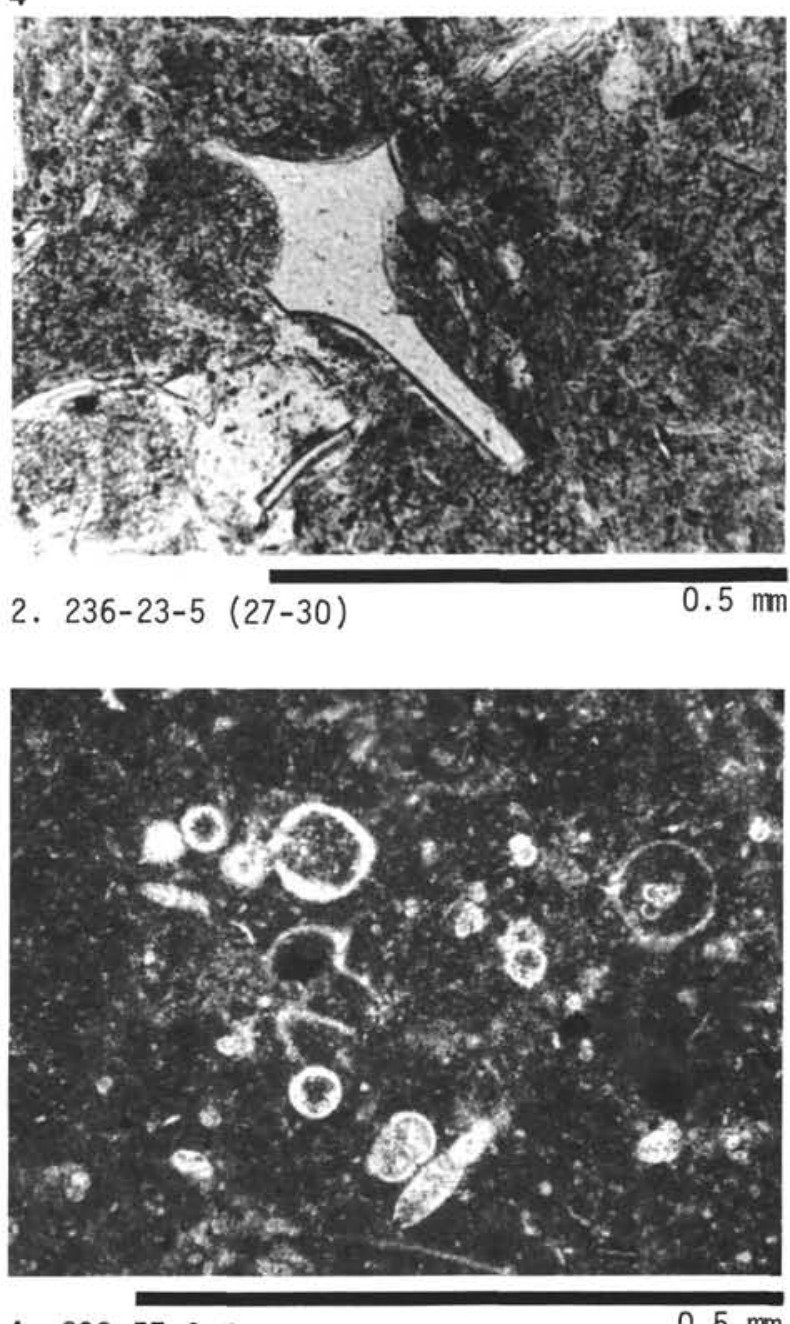

4. $238-57-3-6$

$0.5 \mathrm{~mm}$

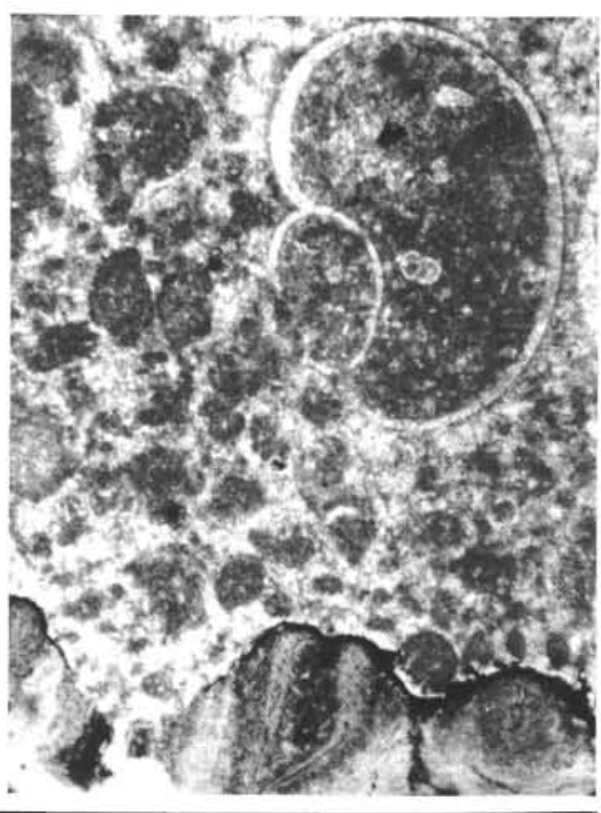

5. $238-58-4-6$

$0.5 \mathrm{~mm}$ 


\section{PLATE 5}

Typical examples of different types of burrows and bioturbation.

Figure $1 \quad 24-231-46-3,52-76 \mathrm{~cm}$.

Figure $2 \quad 24-231-53-4,27-50 \mathrm{~cm}$.

Figure $3 \quad 24-231-56-4,50-74 \mathrm{~cm}$.

Figure $4 \quad 24-231-58-4,2-25 \mathrm{~cm}$.

Figure $5 \quad 24-236-33-2,2-25 \mathrm{~cm}$. 
Plate 5

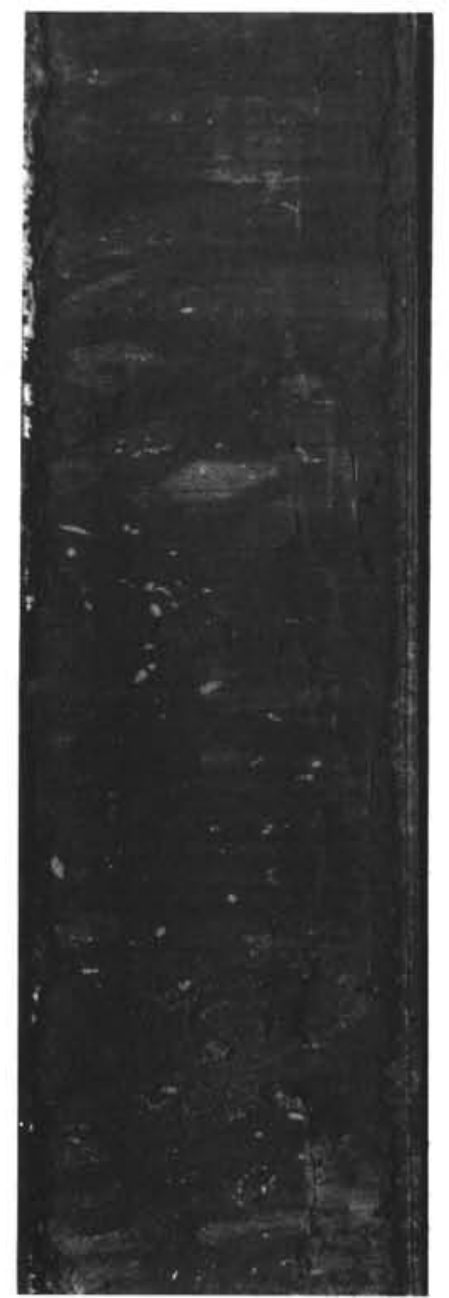

1. $24-231-46-3(52-76)$

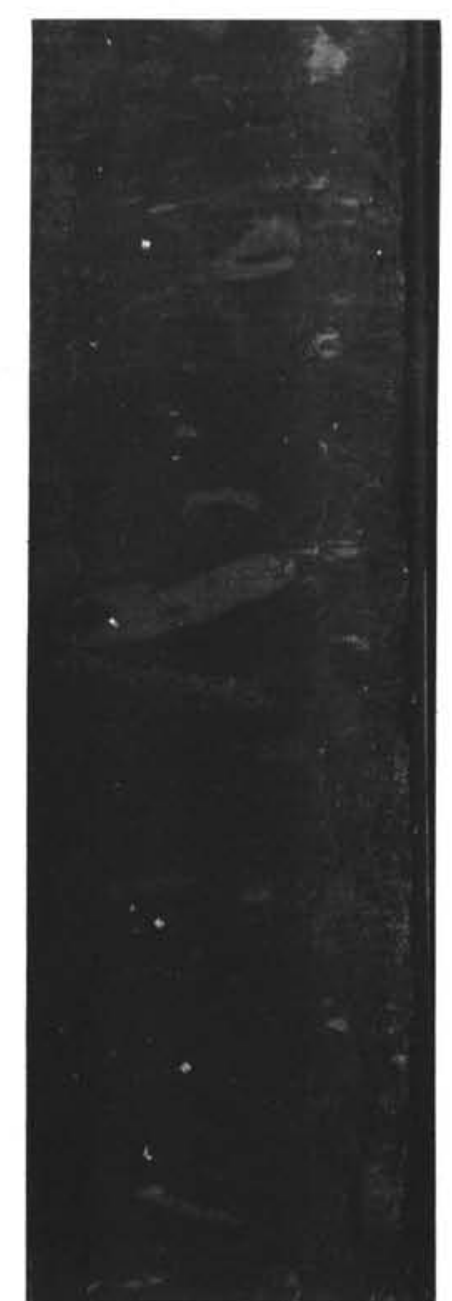

2. $24-231-53-4(27-50)$

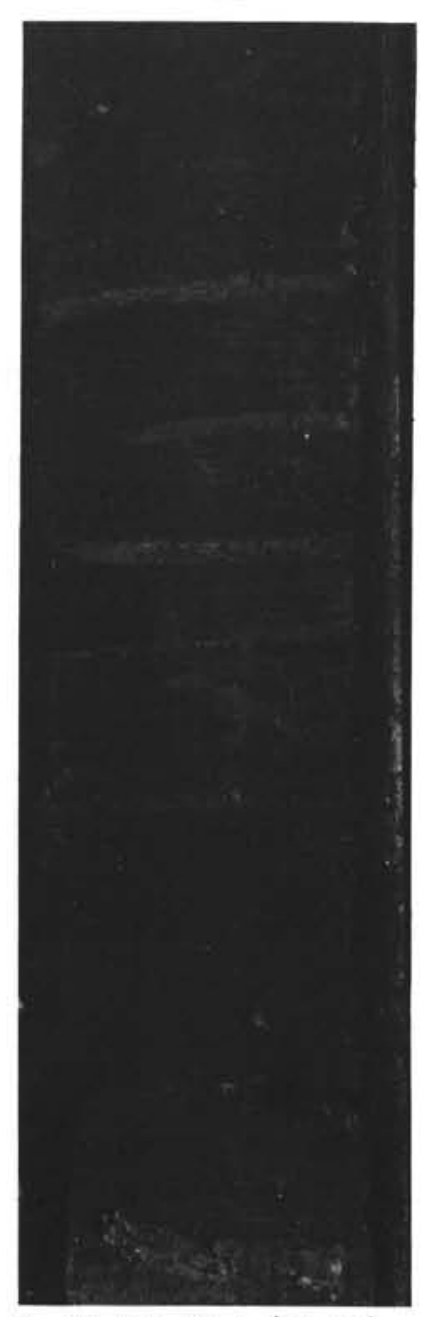

3. $24-231-56-4(50-75)$

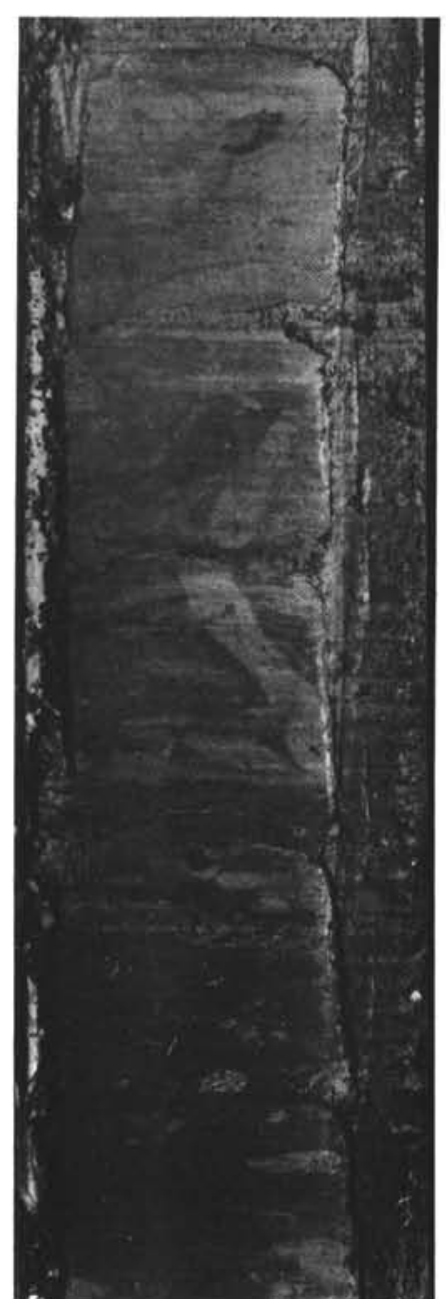

4. $24-231-58-4(2-25)$

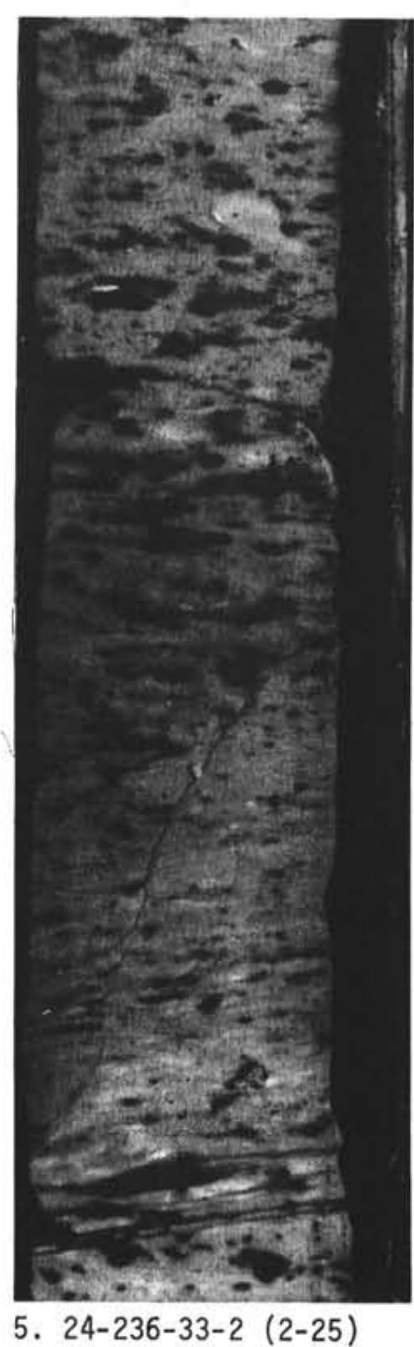

5. $24-236-33-2(2-25)$ 


\section{PLATE 6}

Figure $1 \quad 24-231-14-5,100-125 \mathrm{~cm}$. Sediments consist of lighter layers containing mostly nanno ooze and darker layers containing more benthonic fossils together with more terrigenous material (both in sand, silt, and clay fractions).

Figure 2 24-232-3-6, 100-125 cm. Boundaries of layering are many times not very well defined (also coarse layers are usually not separated from the sediment above and below by very sharp bedding planes). The depositional mechanism of these coarse layers therefore remains unexplained.

Figure $324-232-6-4,75-100 \mathrm{~cm}$. Generally relatively finegrained sediment. Sedimentary structures macroscopically only visible because of color changes.

Figure $4 \quad 23-234-6-4,100-125 \mathrm{~cm}$. Bedding clearly visible due to textural changes.

Figure 5 23-232A-14-1, 100-125 cm. Lamination, crossbedding, and gross textural changes characterize the dark sediments in the lowermost part of Hole 232A. These sediments occur close to the dense, fossiliferous quartzitic sandstones, which are described elsewhere in this volume. 
PLATE 6

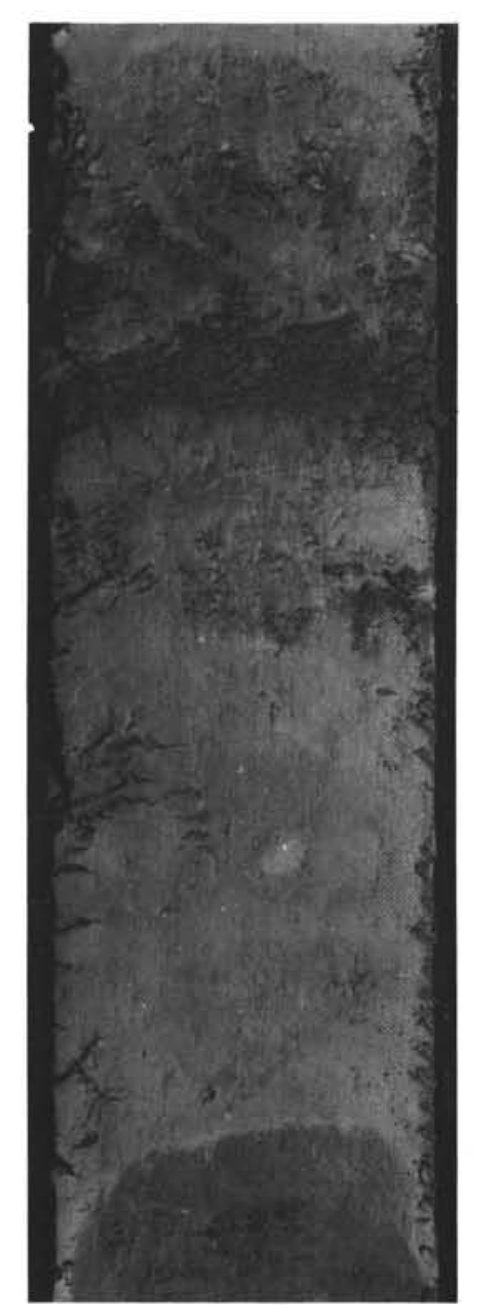

1. $24-231-14-5(100-125)$

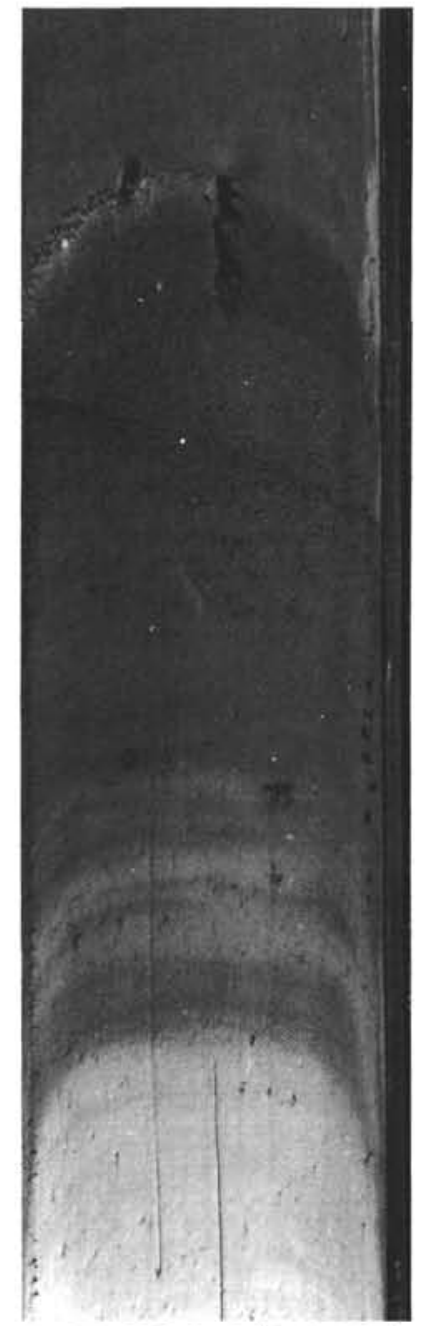

2. $24-232-3-6(100-125)$

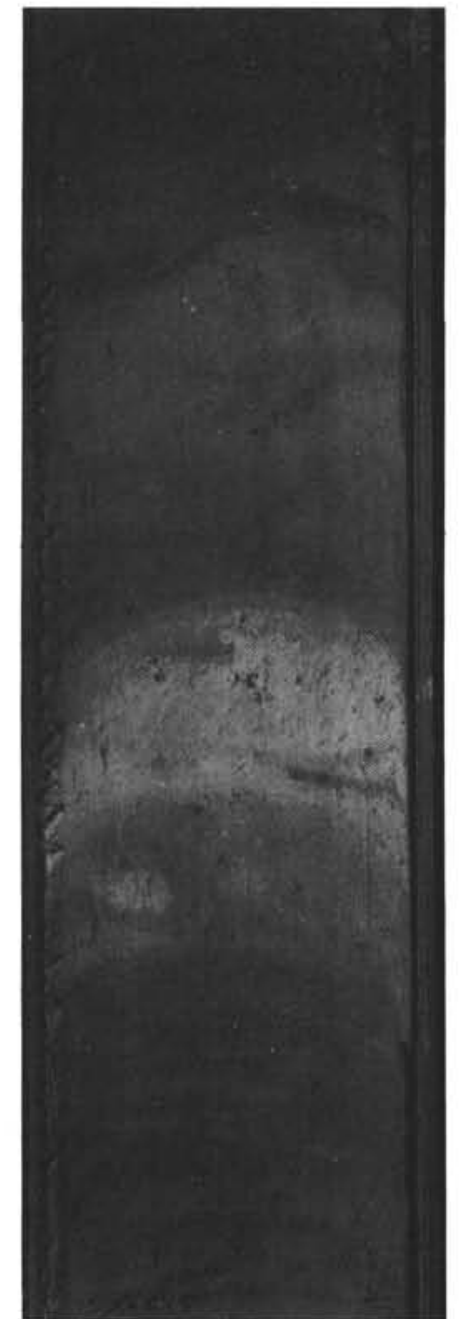

3. $24-232-6-4(75-100)$

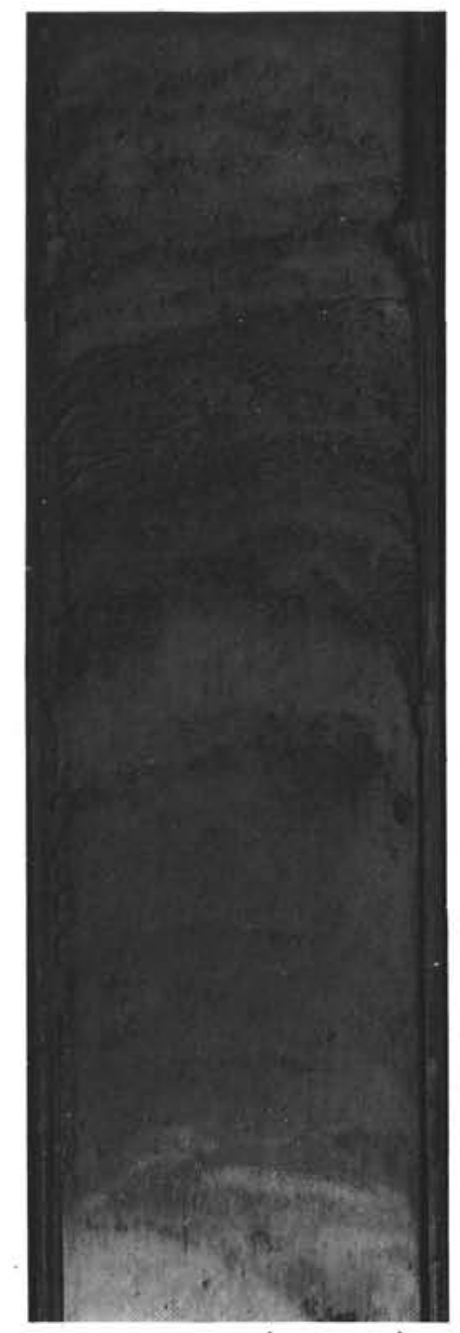

4. $24-232-6-4(100-125)$

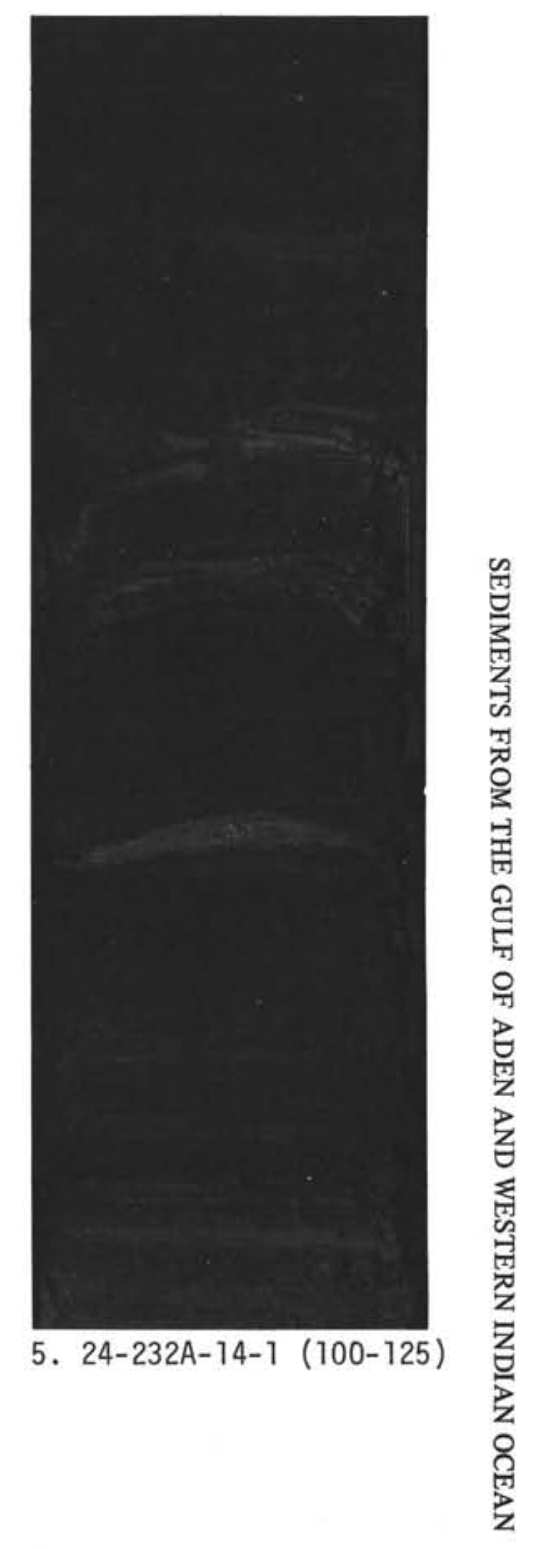

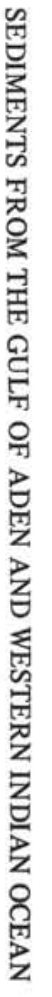




\section{PLATE 7}

Figure $124-233-6-6,0-25 \mathrm{~cm}$. Typical layering in the upper part of Site 233. There are no big compositional differences between both types of sediment.

Figure 2 24-234-5-2, 100-125 cm. Badly disturbed (due to coring technique) interlayering of clays (darker colors) and nanno-bearing to nanno-rich clays.

Figure $3 \quad 24-234-9-1,75-100 \mathrm{~cm}$. Similar sediments as shown in Figure 2.

Figure $4 \quad 24-235-11-4,50-75 \mathrm{~cm}$. Yellowish-gray nanno ooze with intercalated darker nanno-rich to bearing clays.

Figure $5 \quad 24-235-13-1,75-100 \mathrm{~cm}$. Thin yellowish-gray nanno ooze horizon (with some small dark burrows) intercalated into nanno-rich clay. 
PLATE 7

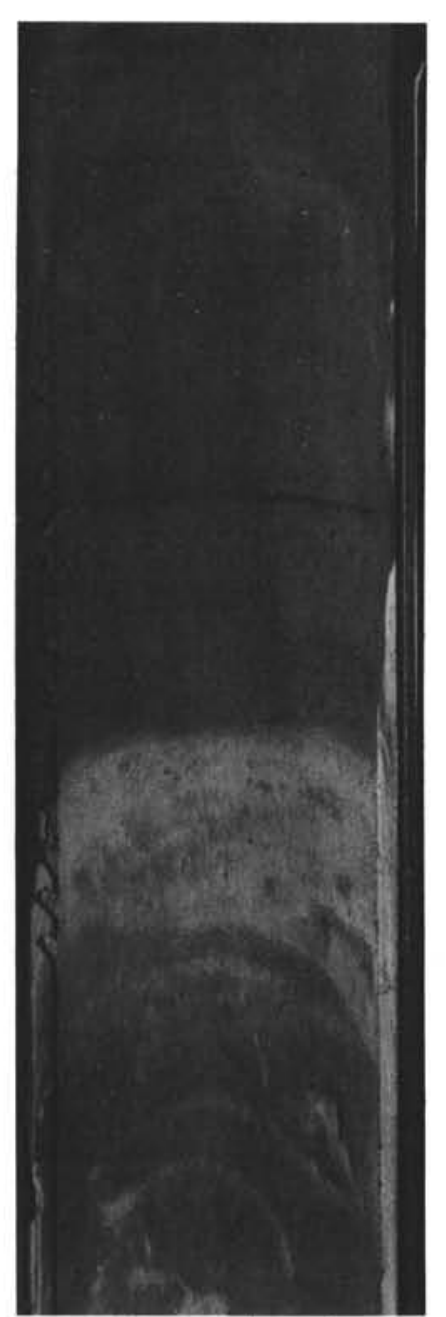

1. $24-233-6-6(0-25)$

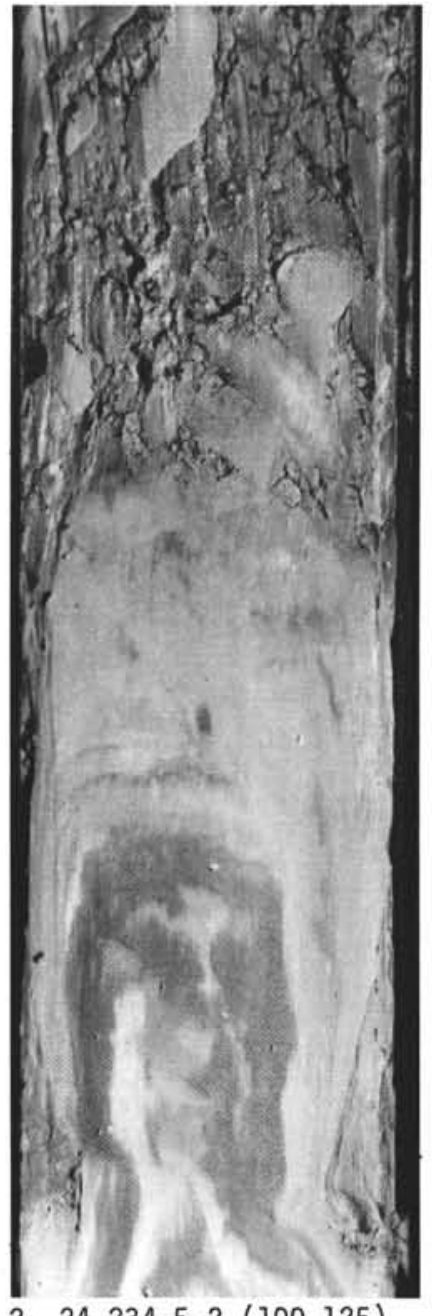

2. $24-234-5-2(100-125)$

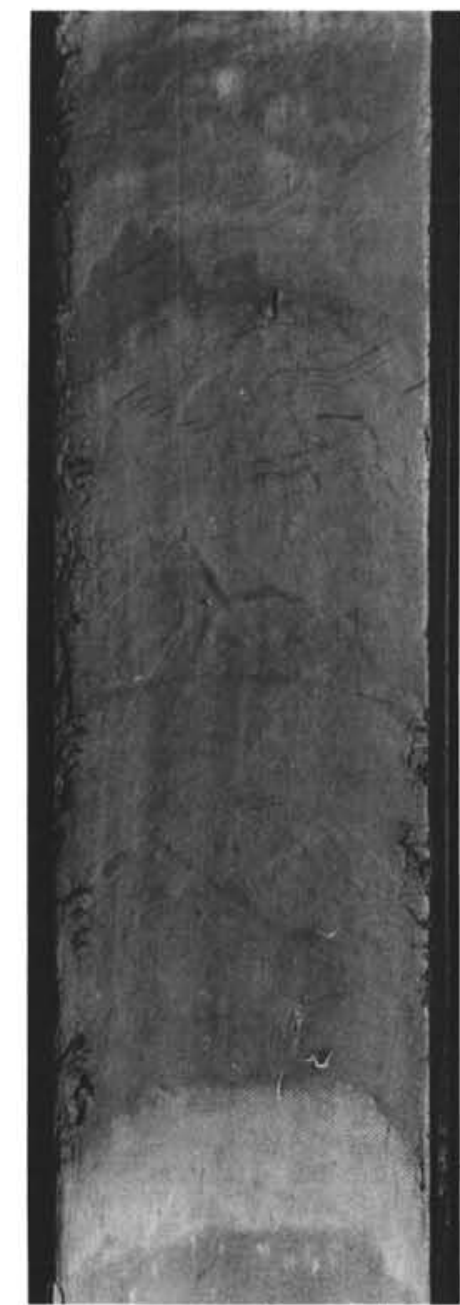

3. $24-234-9-1$ (75-100)

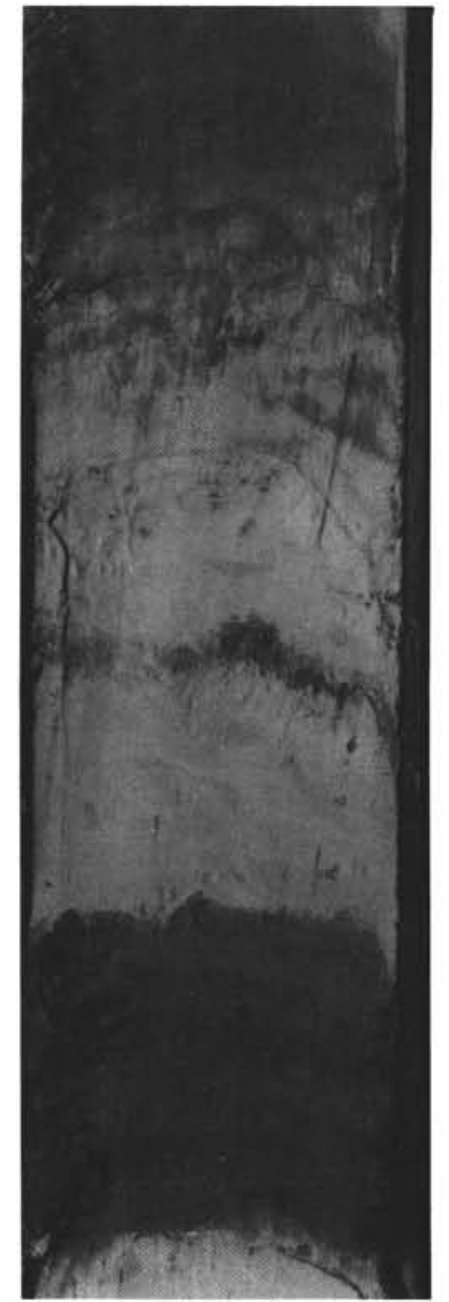

4. $24-235-11-4(50-75)$

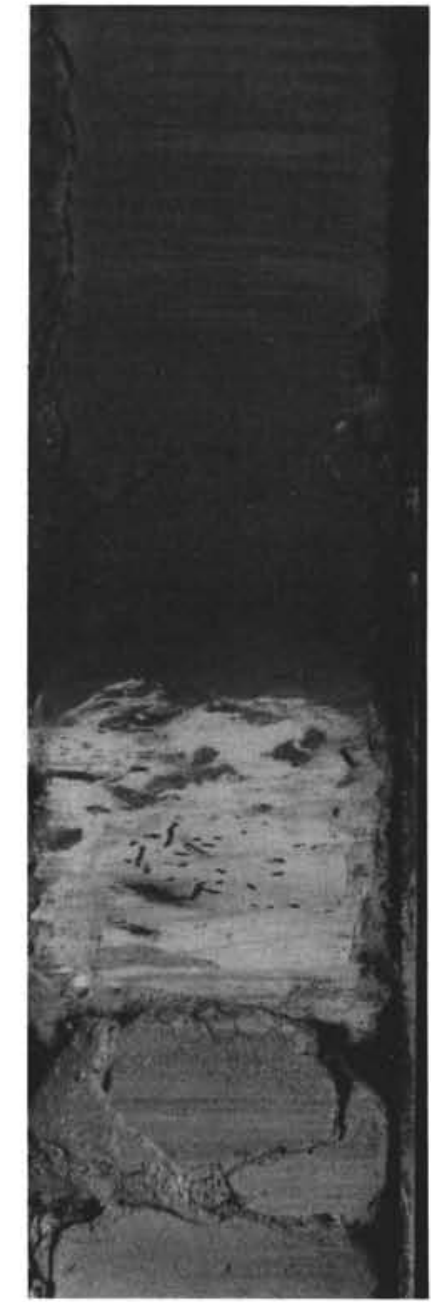

5. 24-235-13-1 (75-100) 


\section{PLATE 8}

Figures 1,2 The very fine grained clays and nanno oozes revealed many times very sharp boundaries between layers of different composition, indicating very sudden (in a geologic sense) environmental or depositional changes. 1. 24-235-13-3, 100-125 cm. 2. $24-235-15-3,119-142 \mathrm{~cm}$.

Figure $3 \quad 24-236-10-5,98-121 \mathrm{~cm}$. Very light gray foram-rich nanno ooze intercalated into dusky yellow-green nanno ooze.

Figure $4 \quad 24-238-54-1,75-97 \mathrm{~cm}$. Basal sediments directly above the basaltic basement. The sediment consists of thinly bedded zeolitic sands, iron-oxide-rich sandy volcanic ashes, and nanno ooze. 

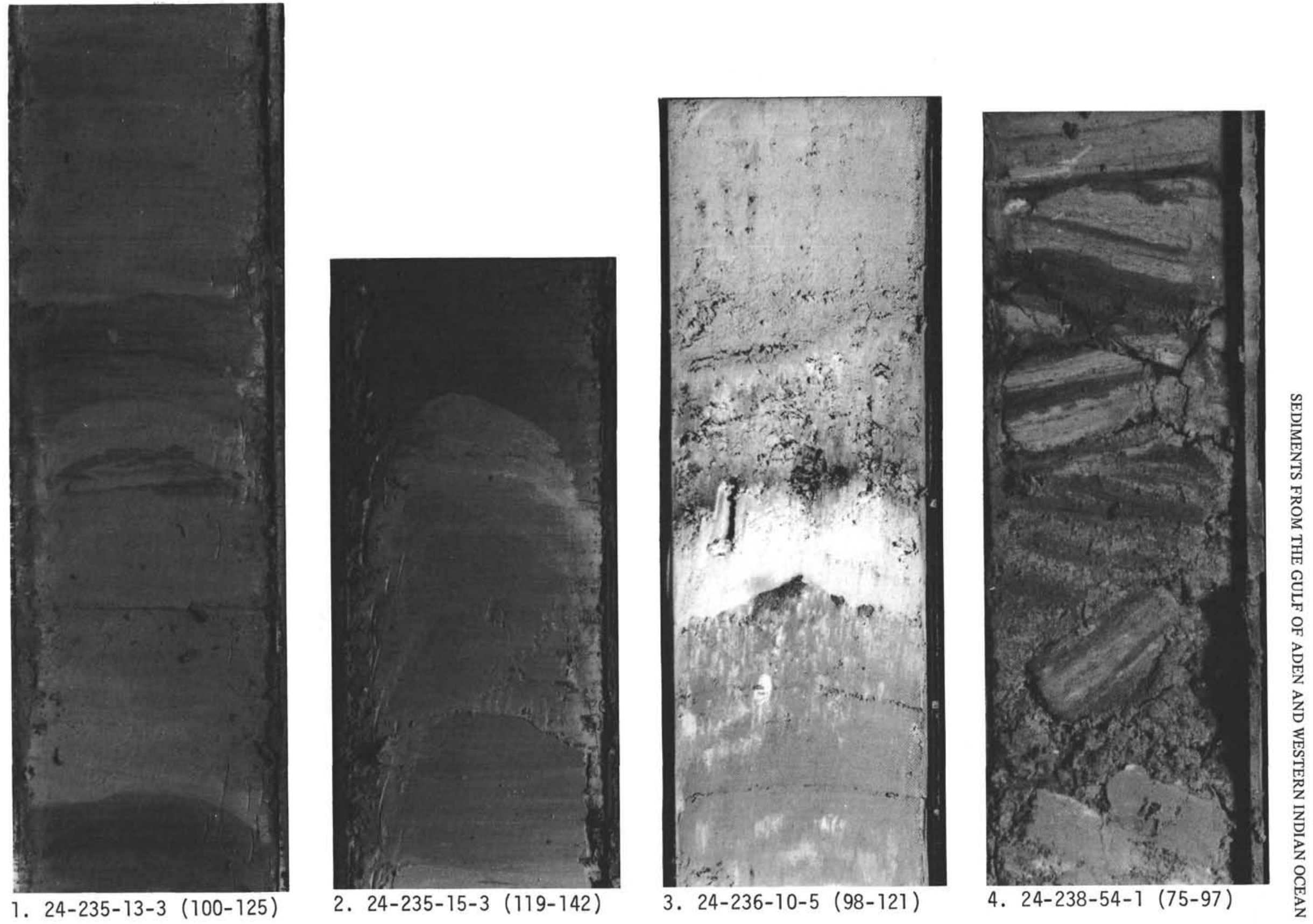


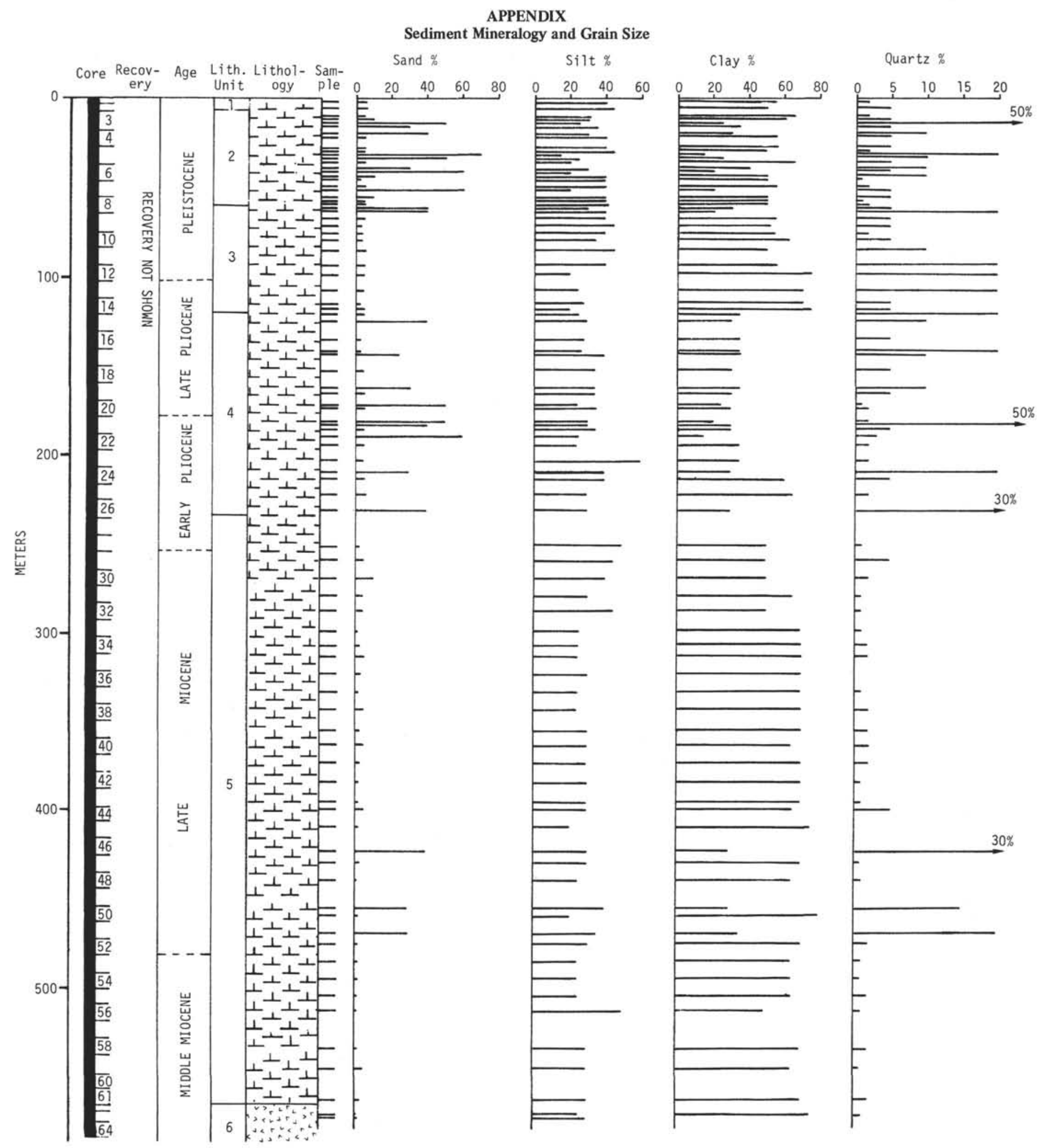




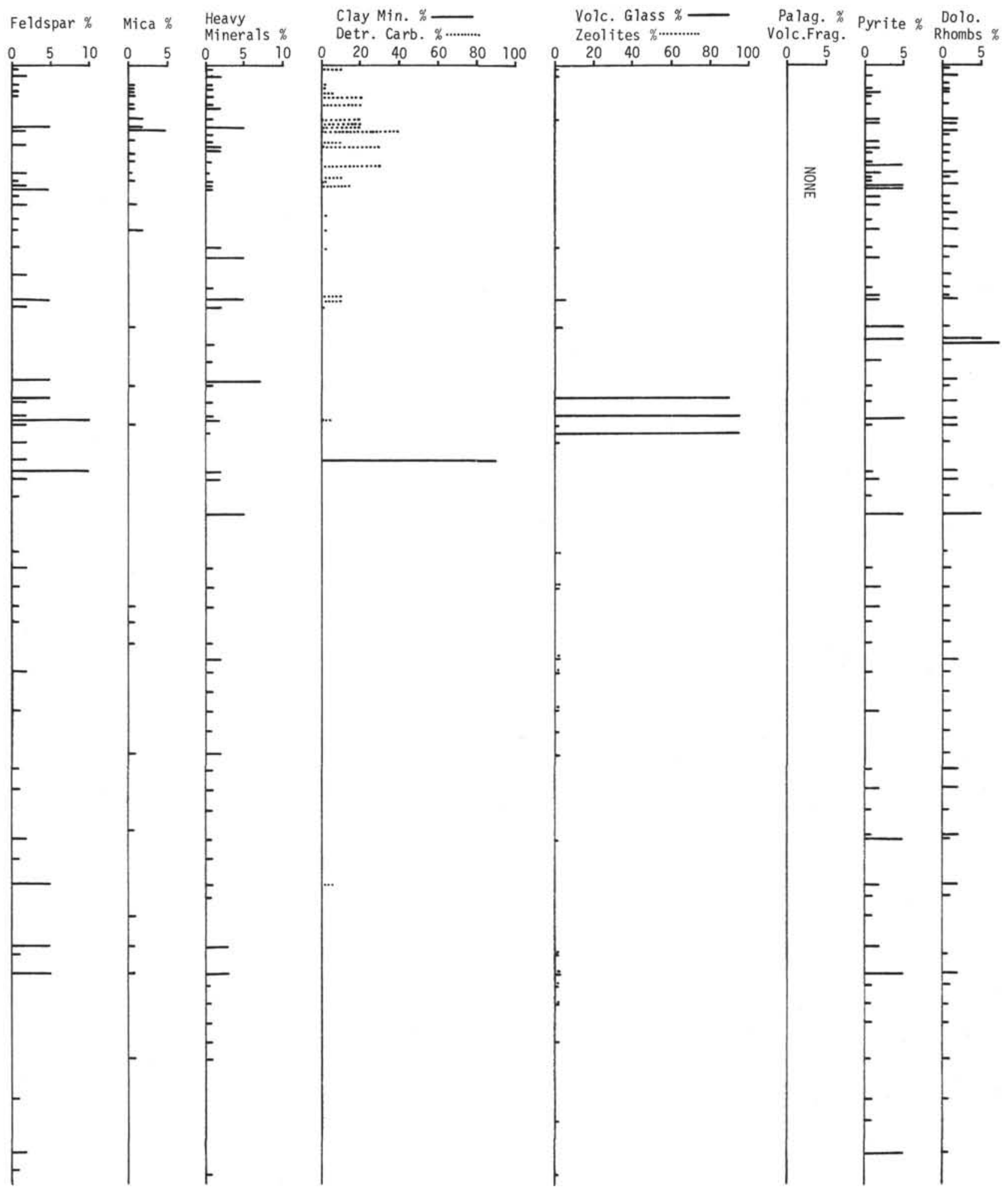




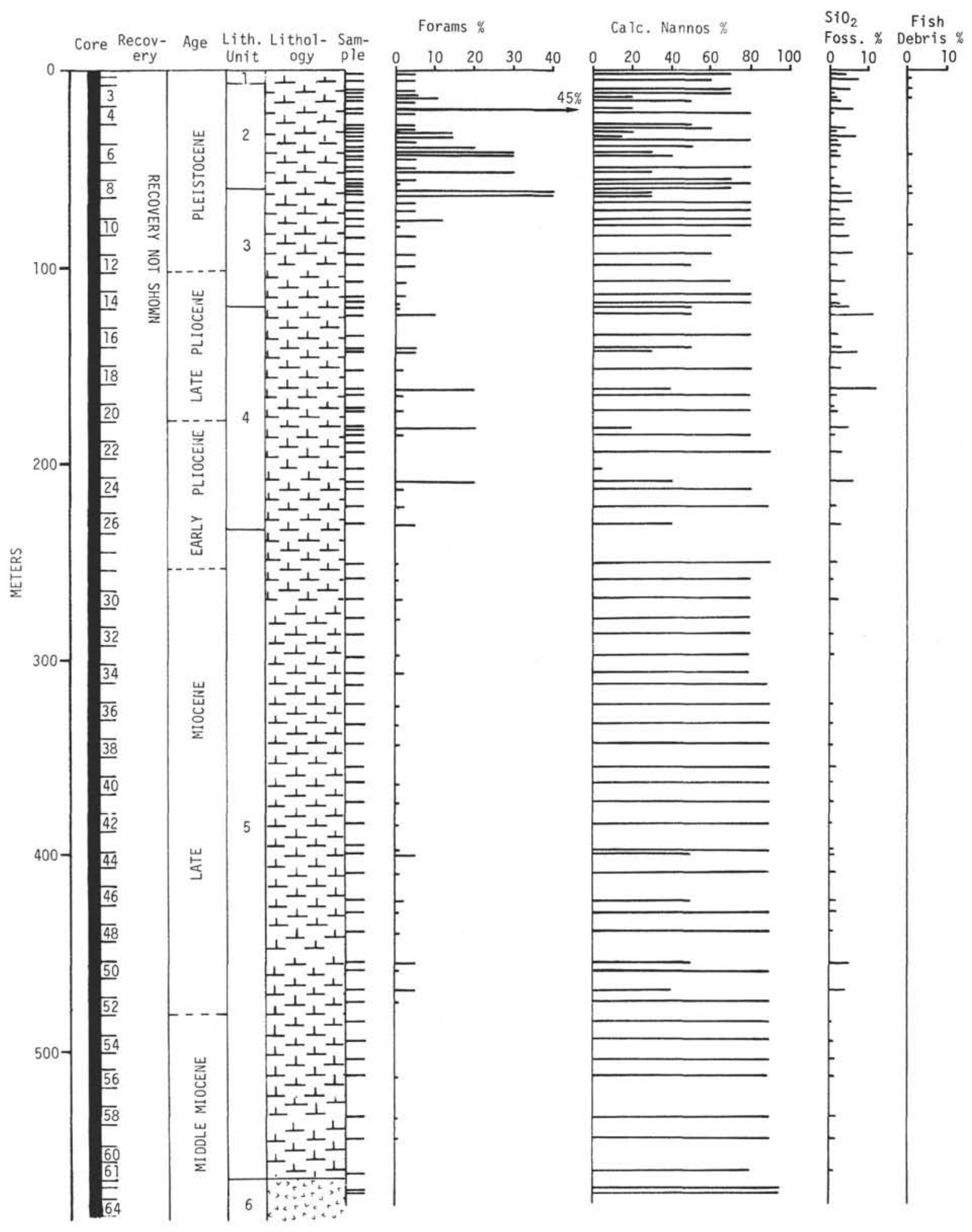



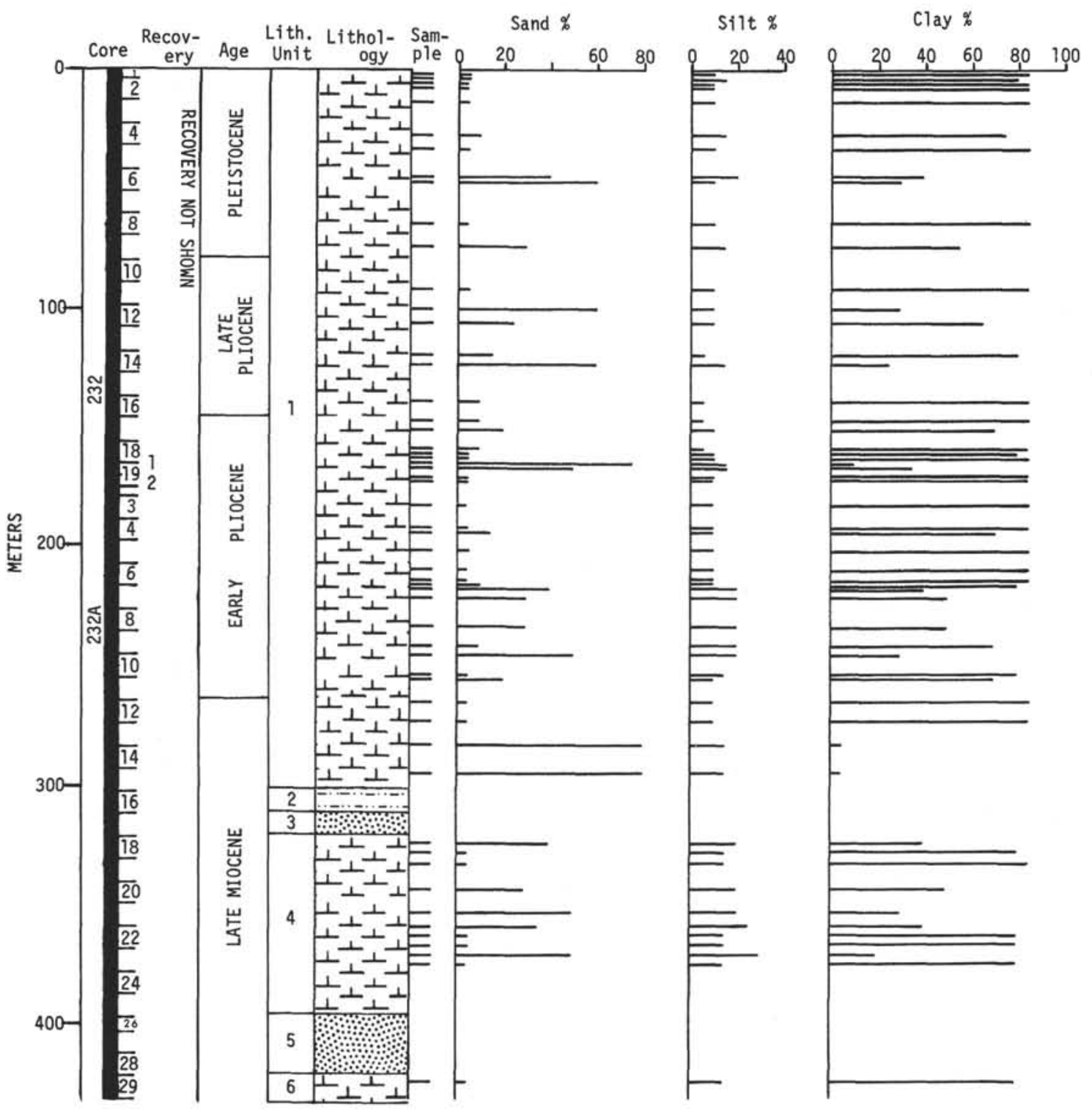


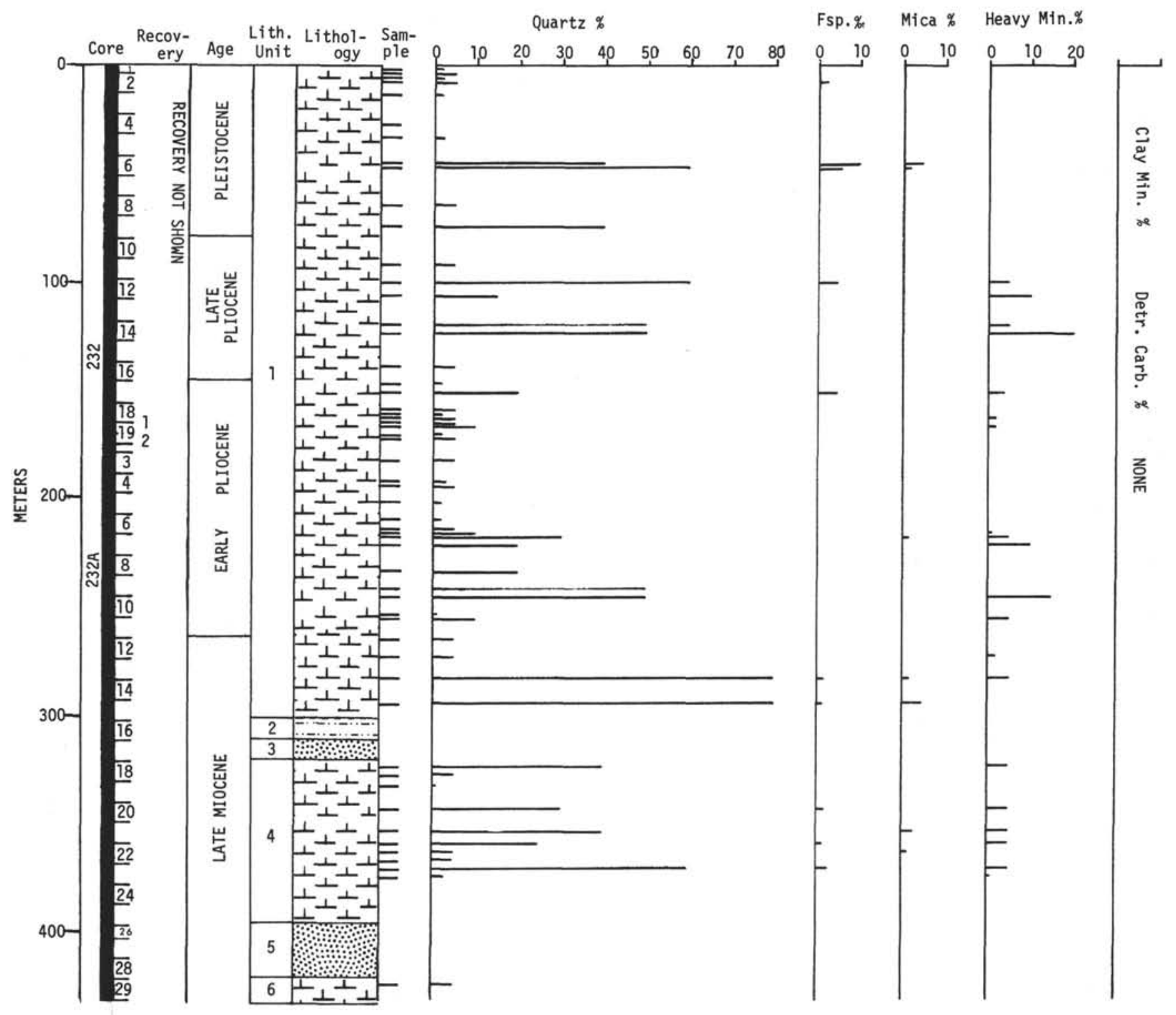




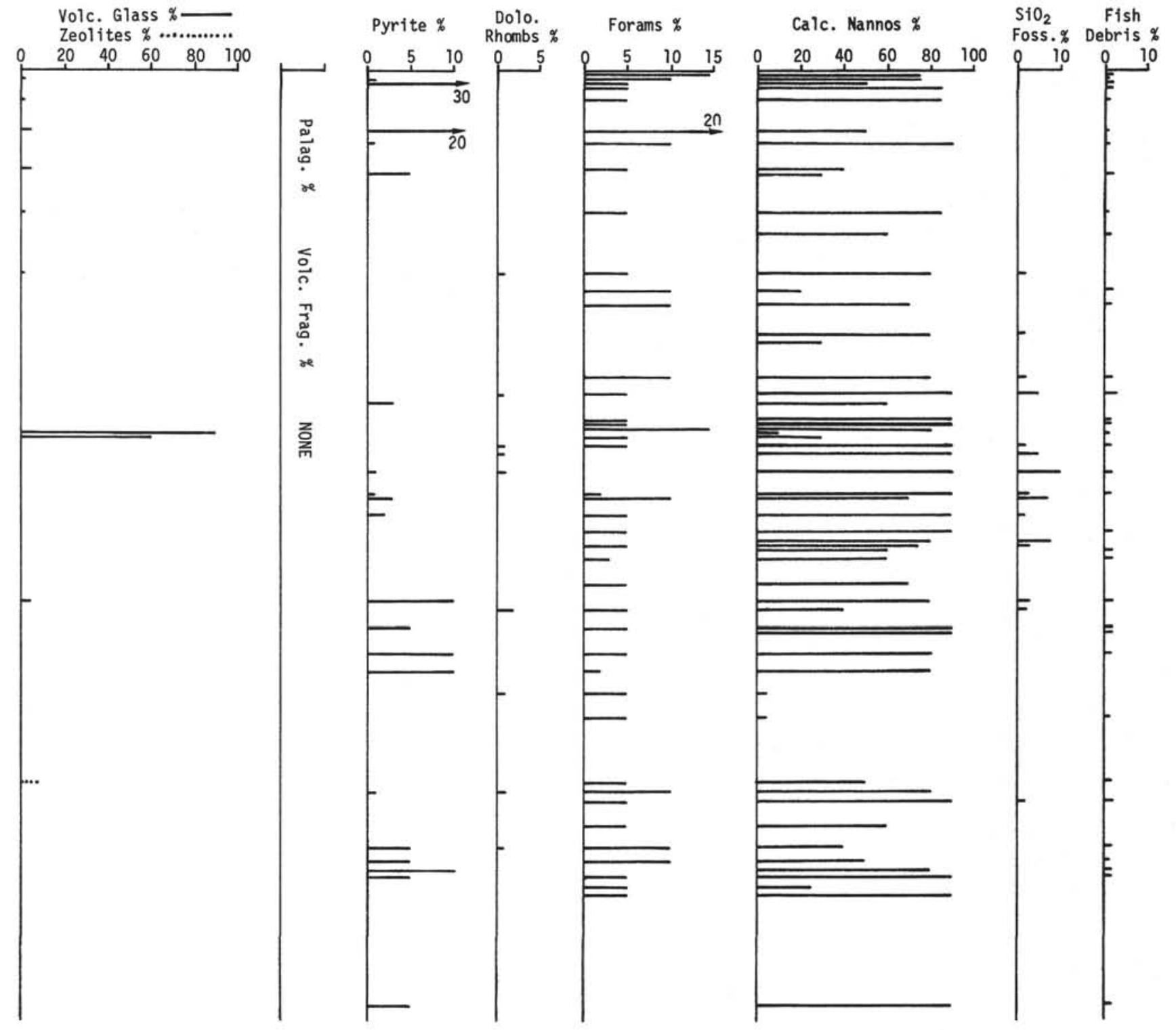




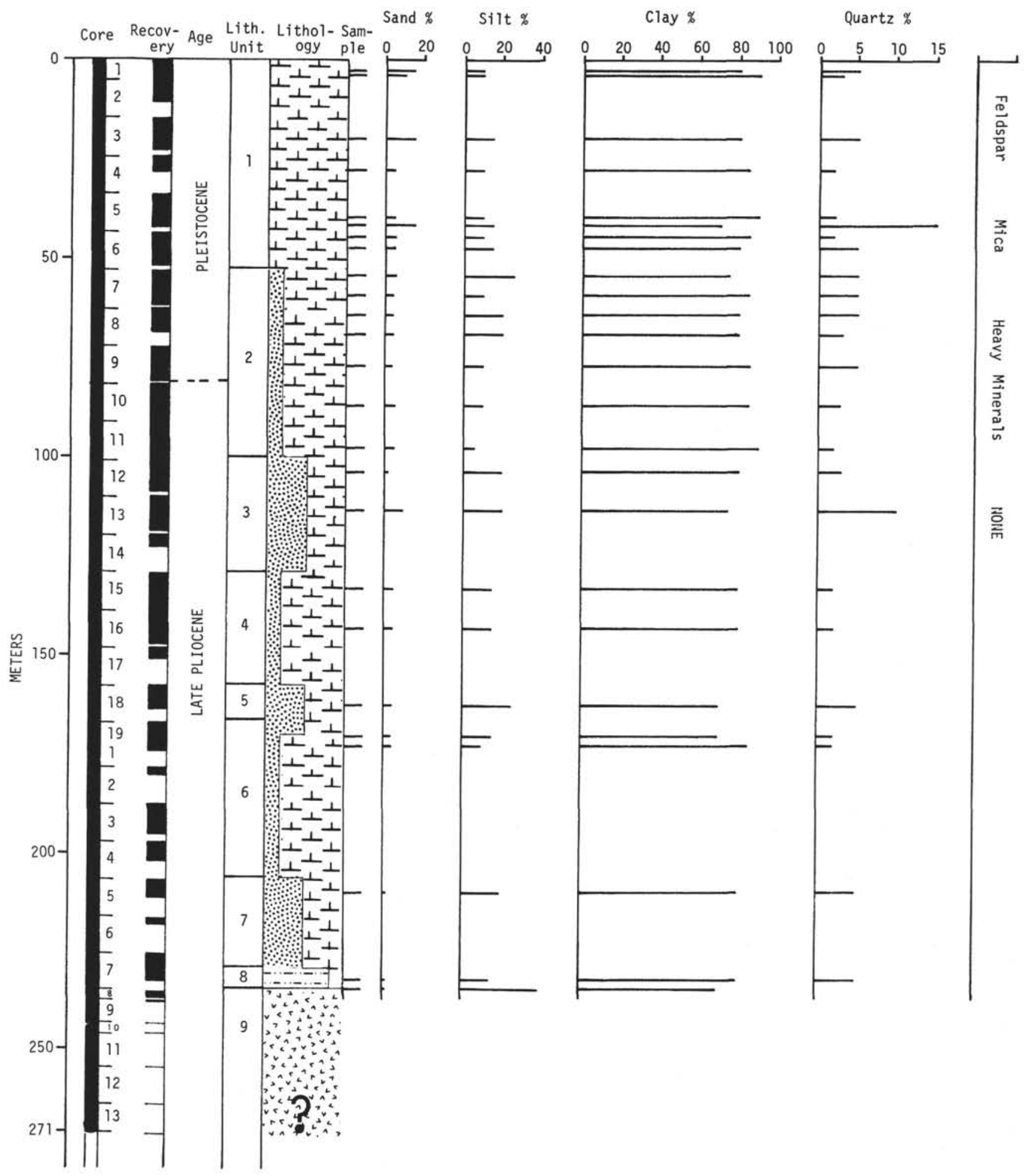




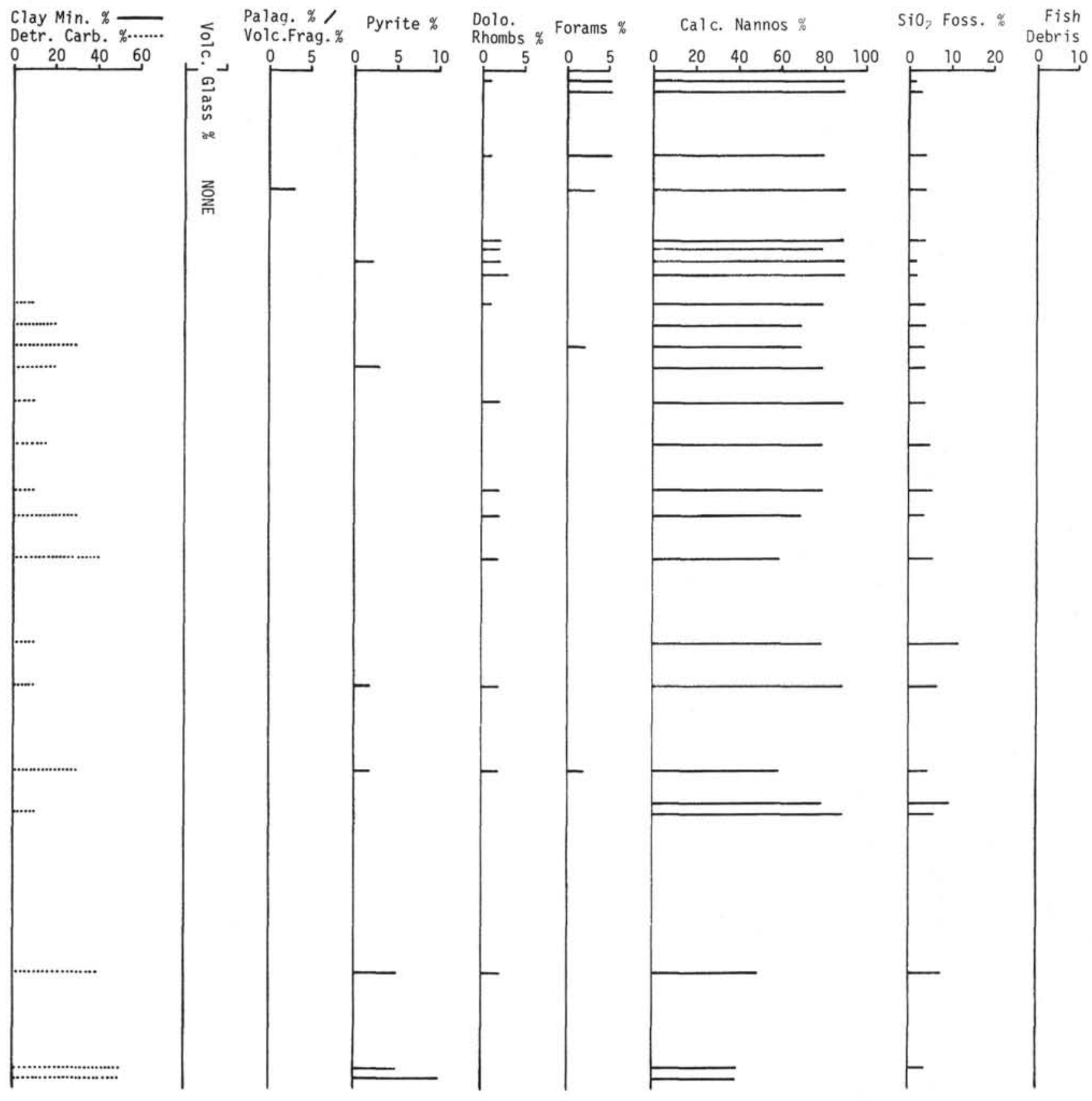




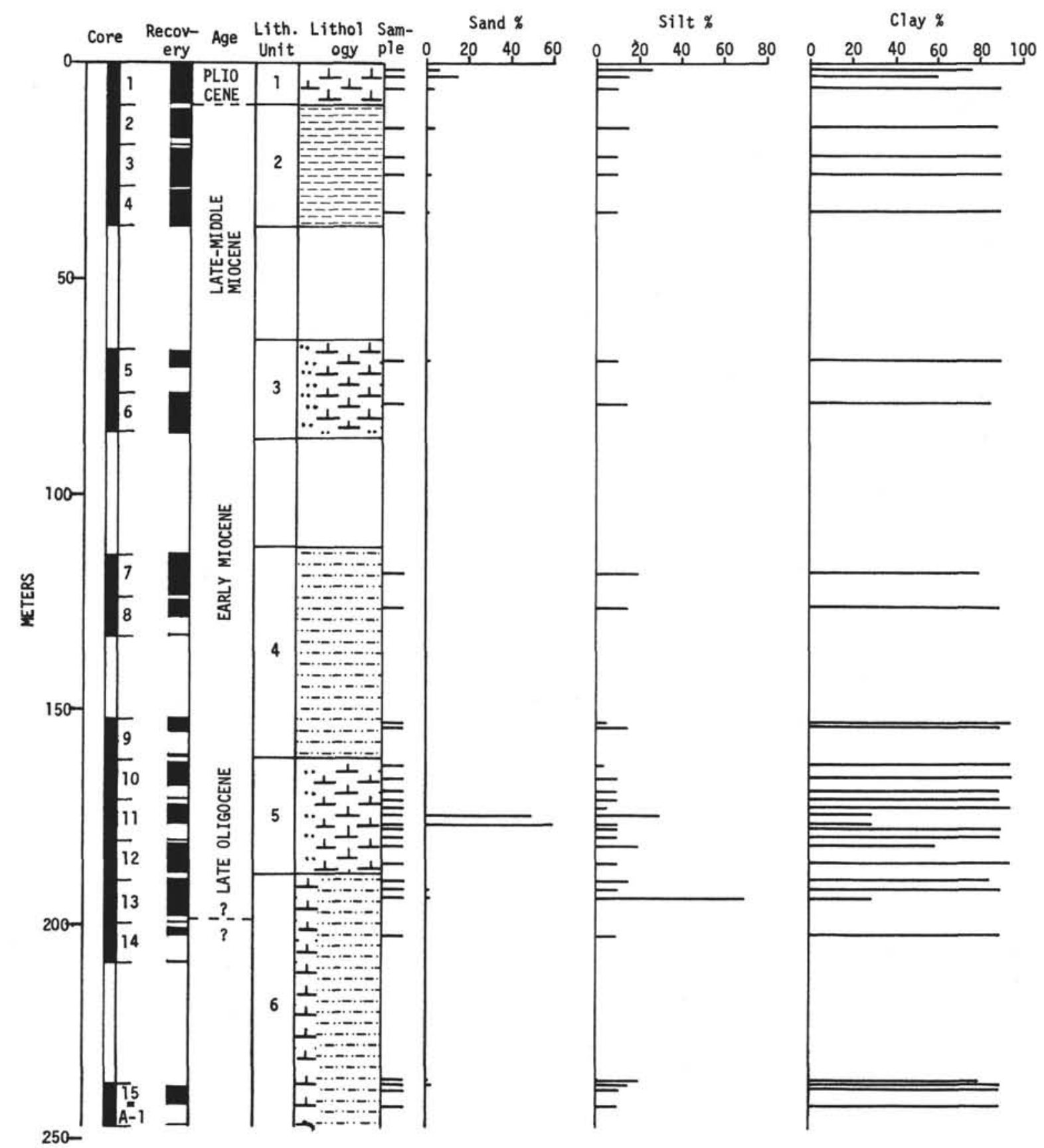




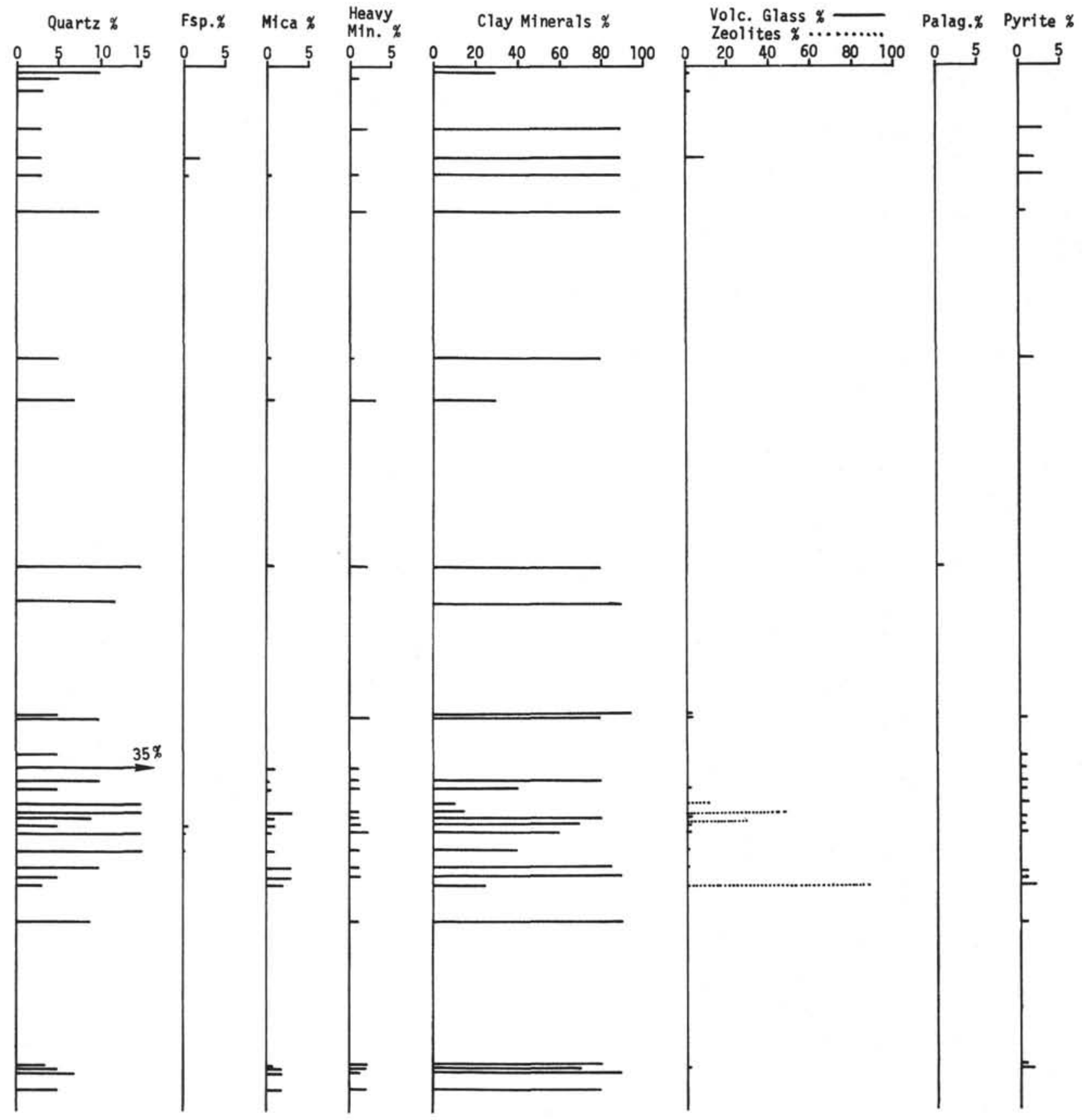




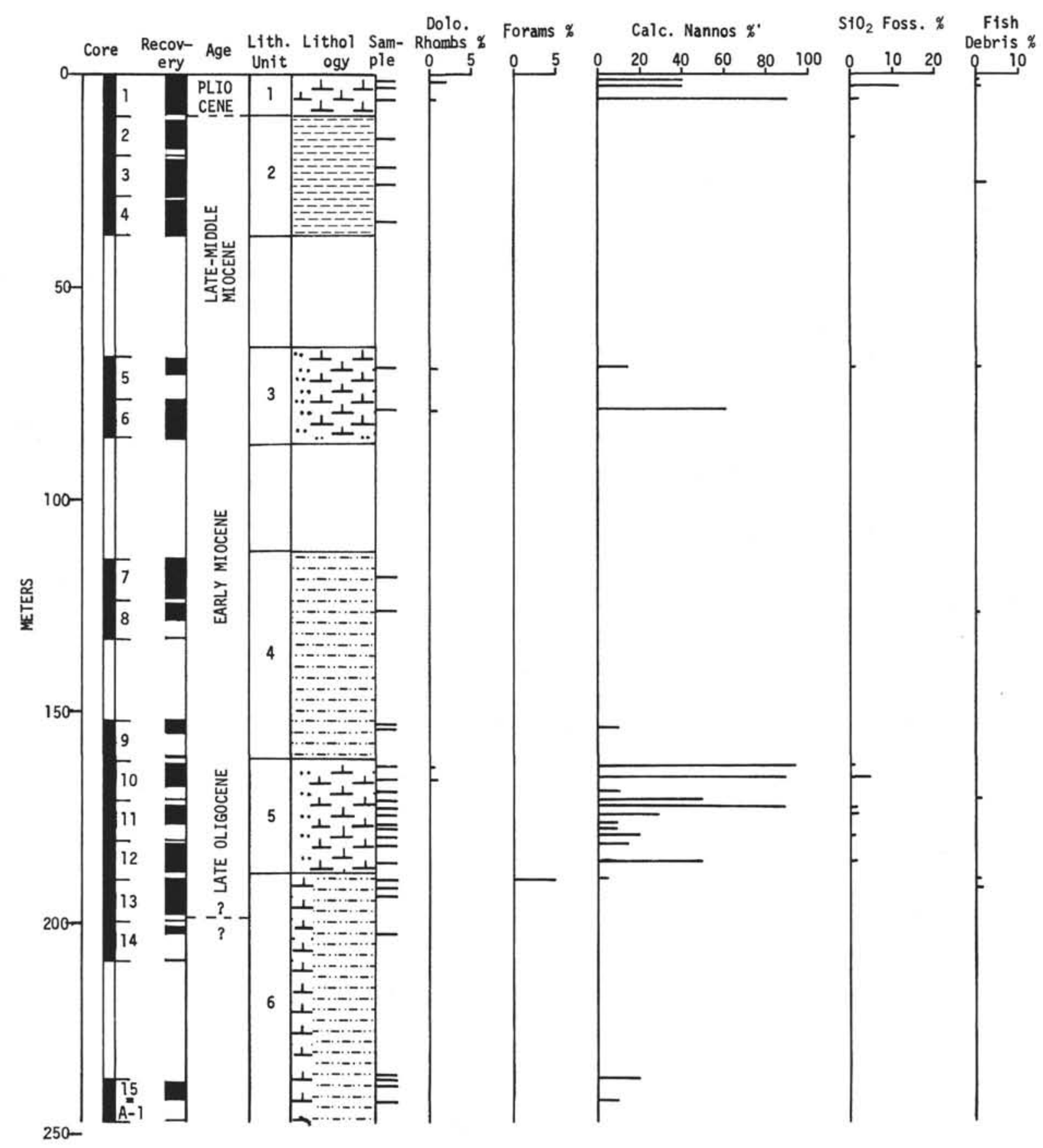



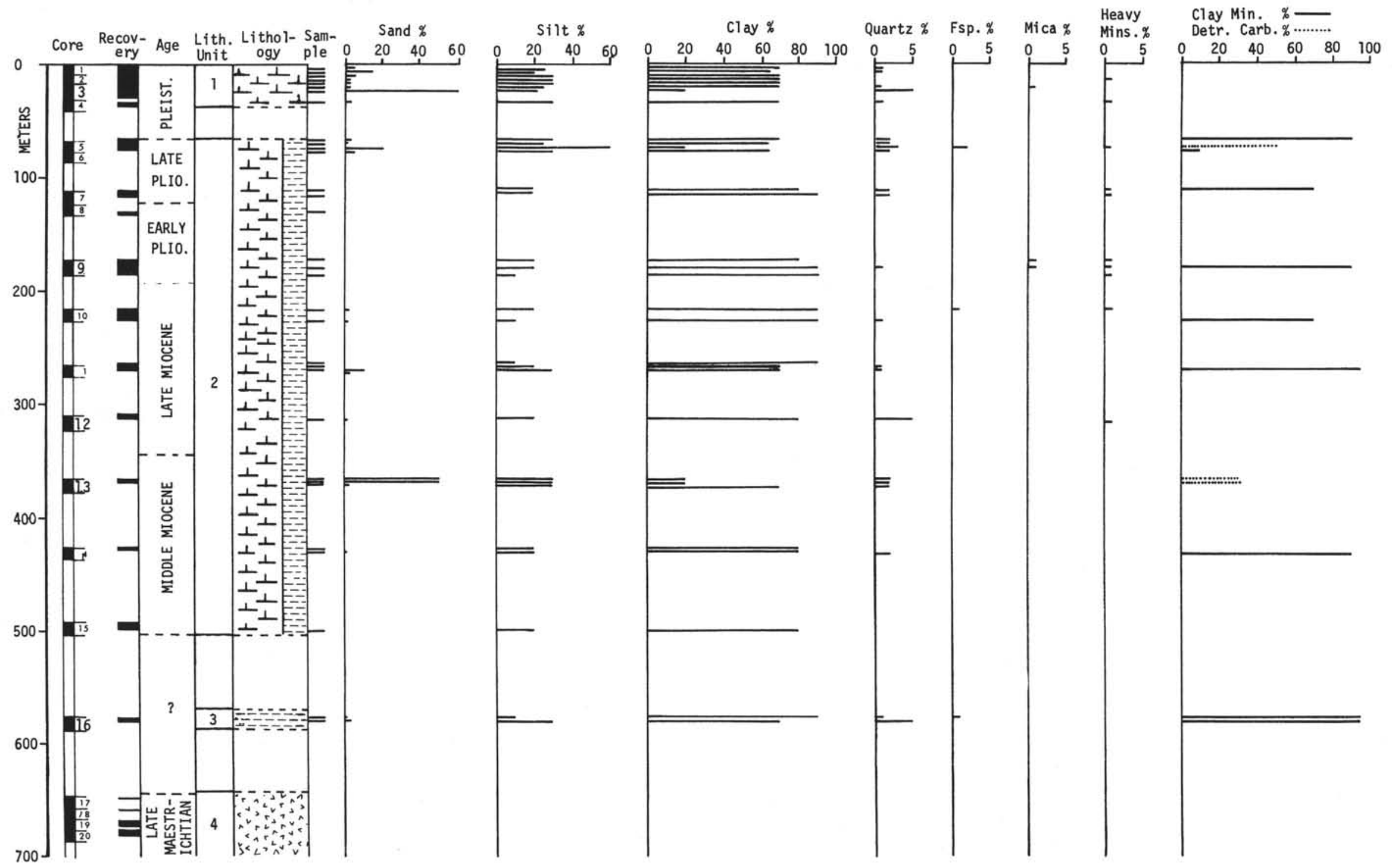

-

Mins.\% $\begin{array}{lllll}20 & 40 & 60 & 80 & 100\end{array}$

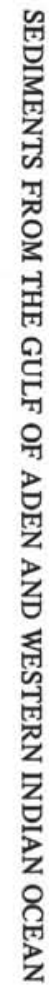




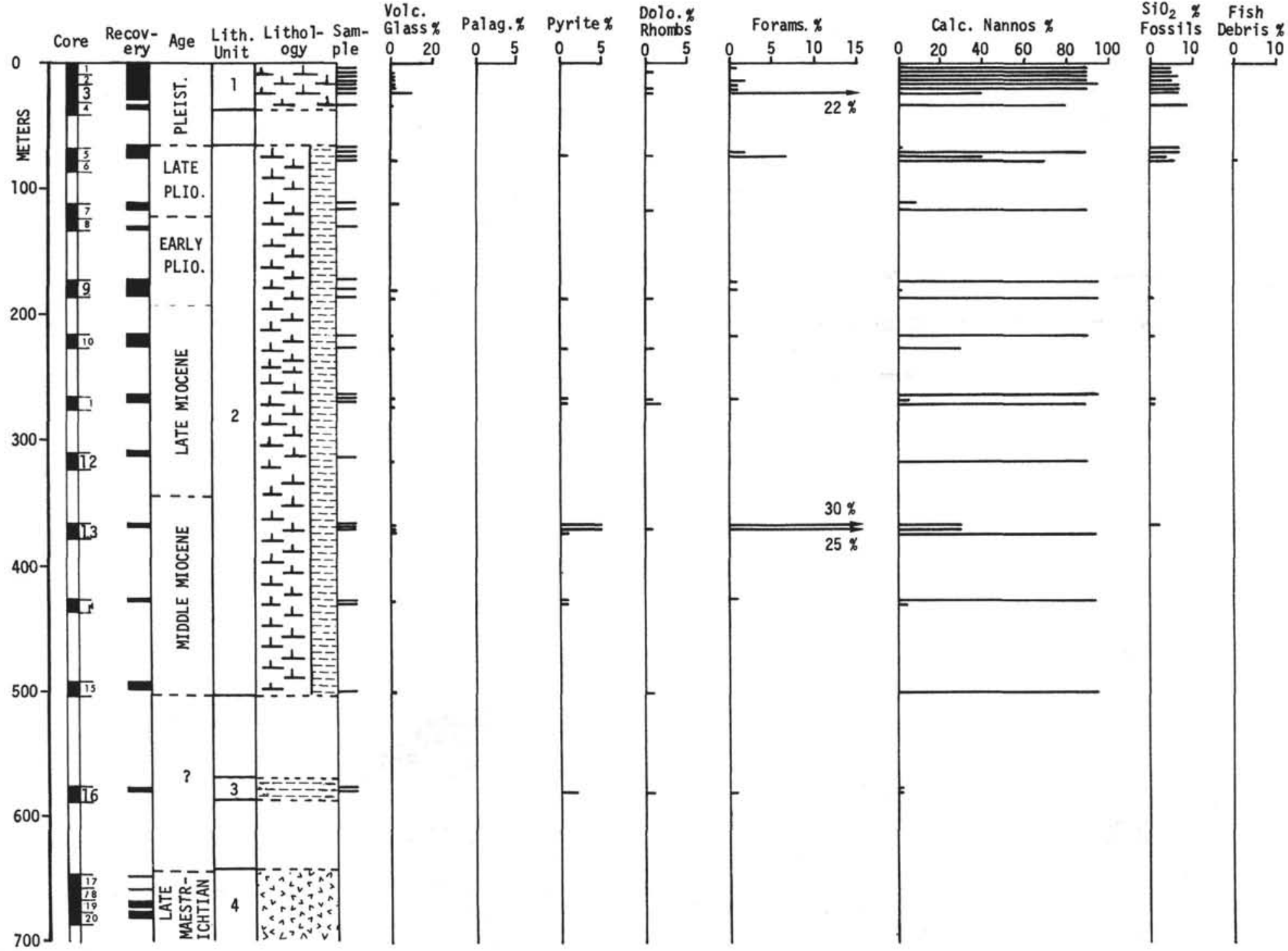




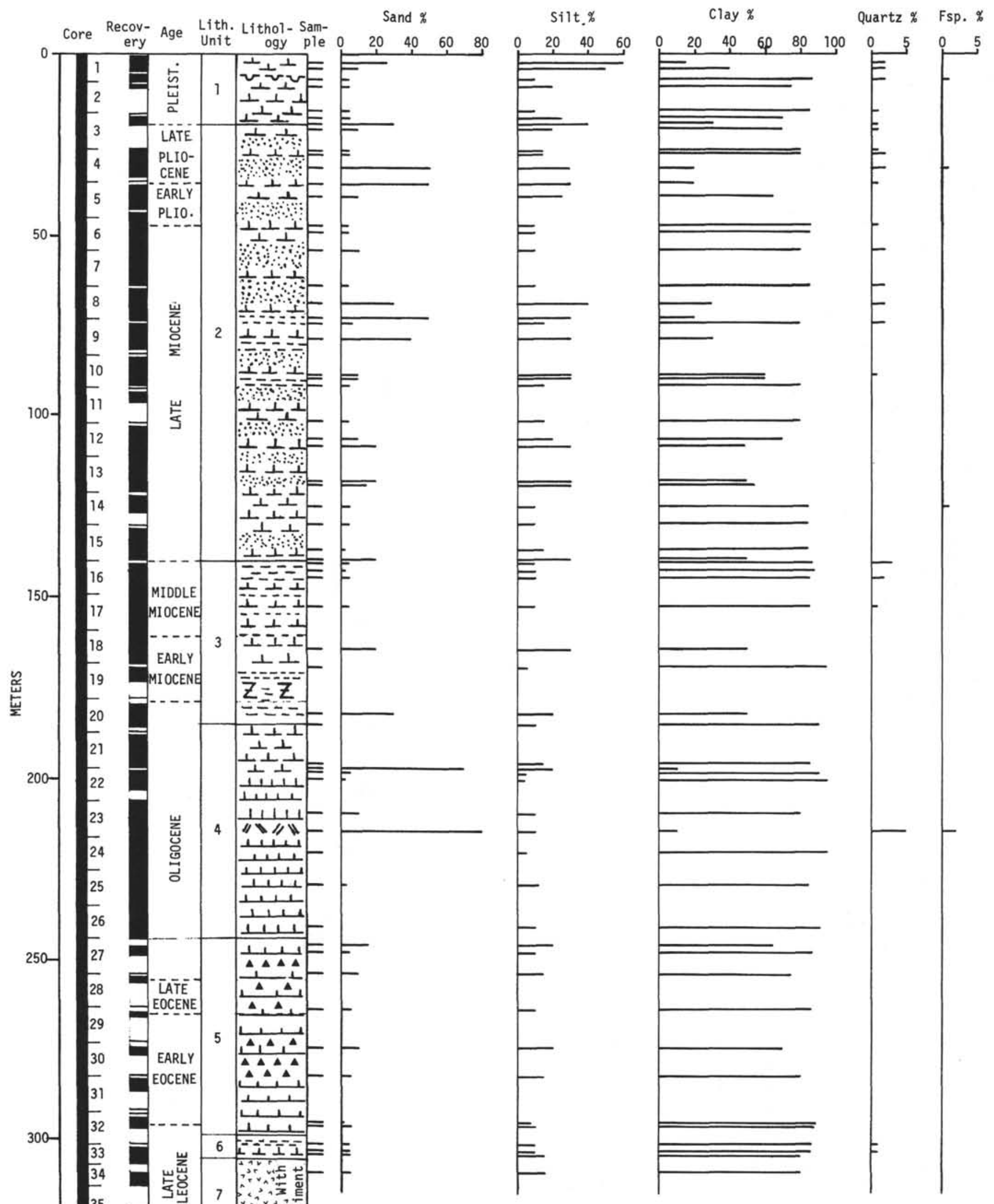


D. S. CRONAN ET AL.

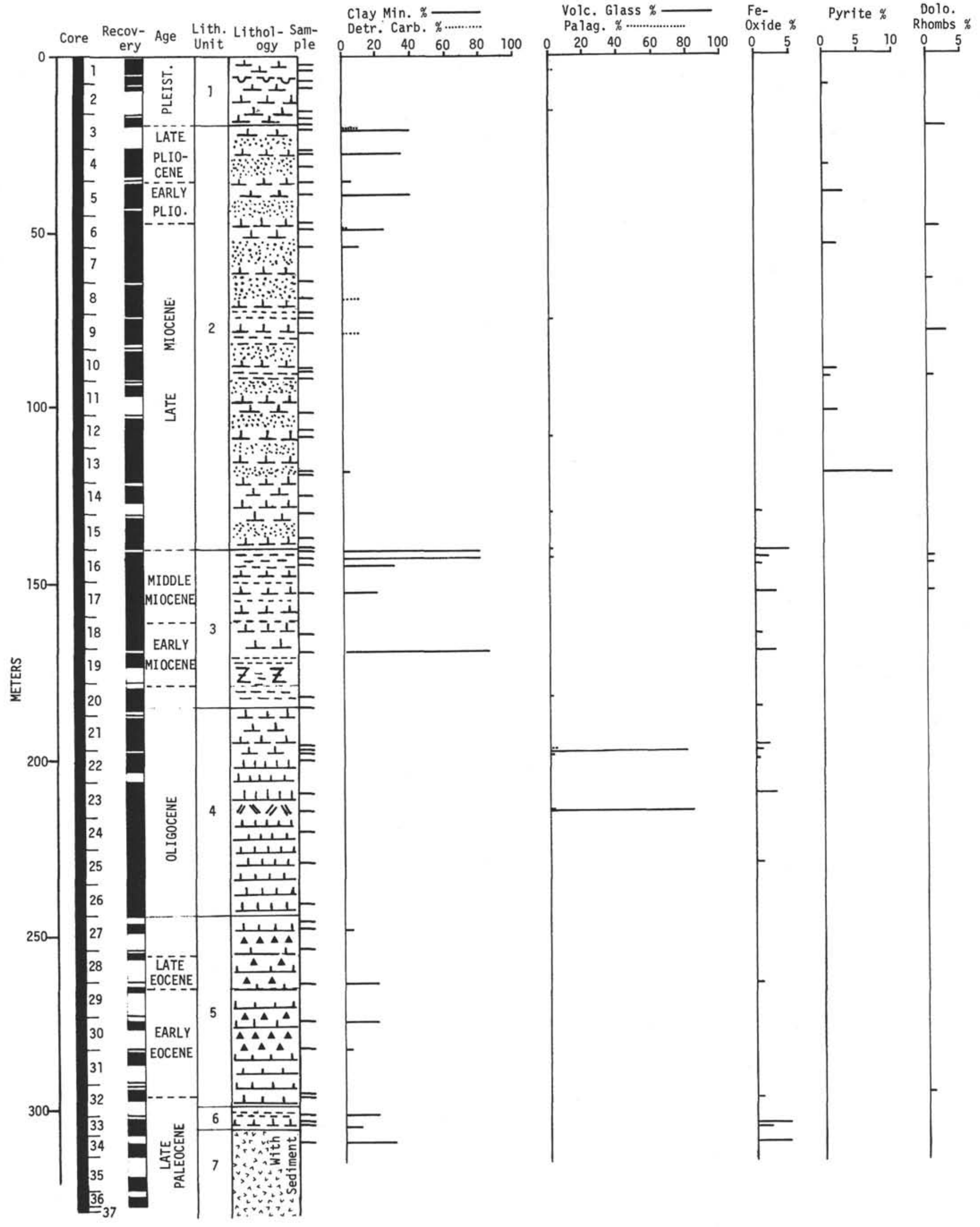


SEDIMENTS FROM THE GULF OF ADEN AND WESTERN INDIAN OCEAN

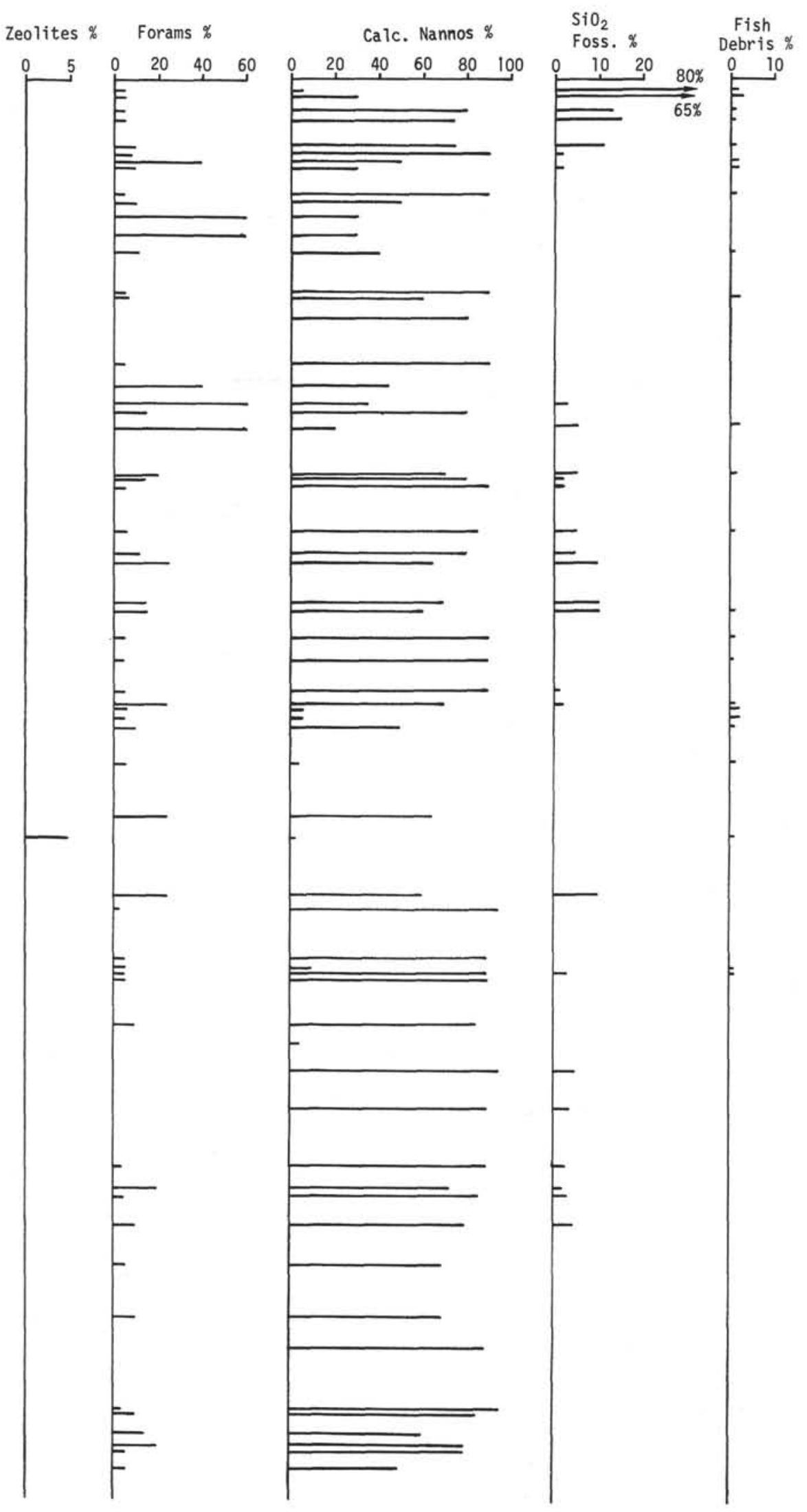


D. S. CRONAN ET AL.

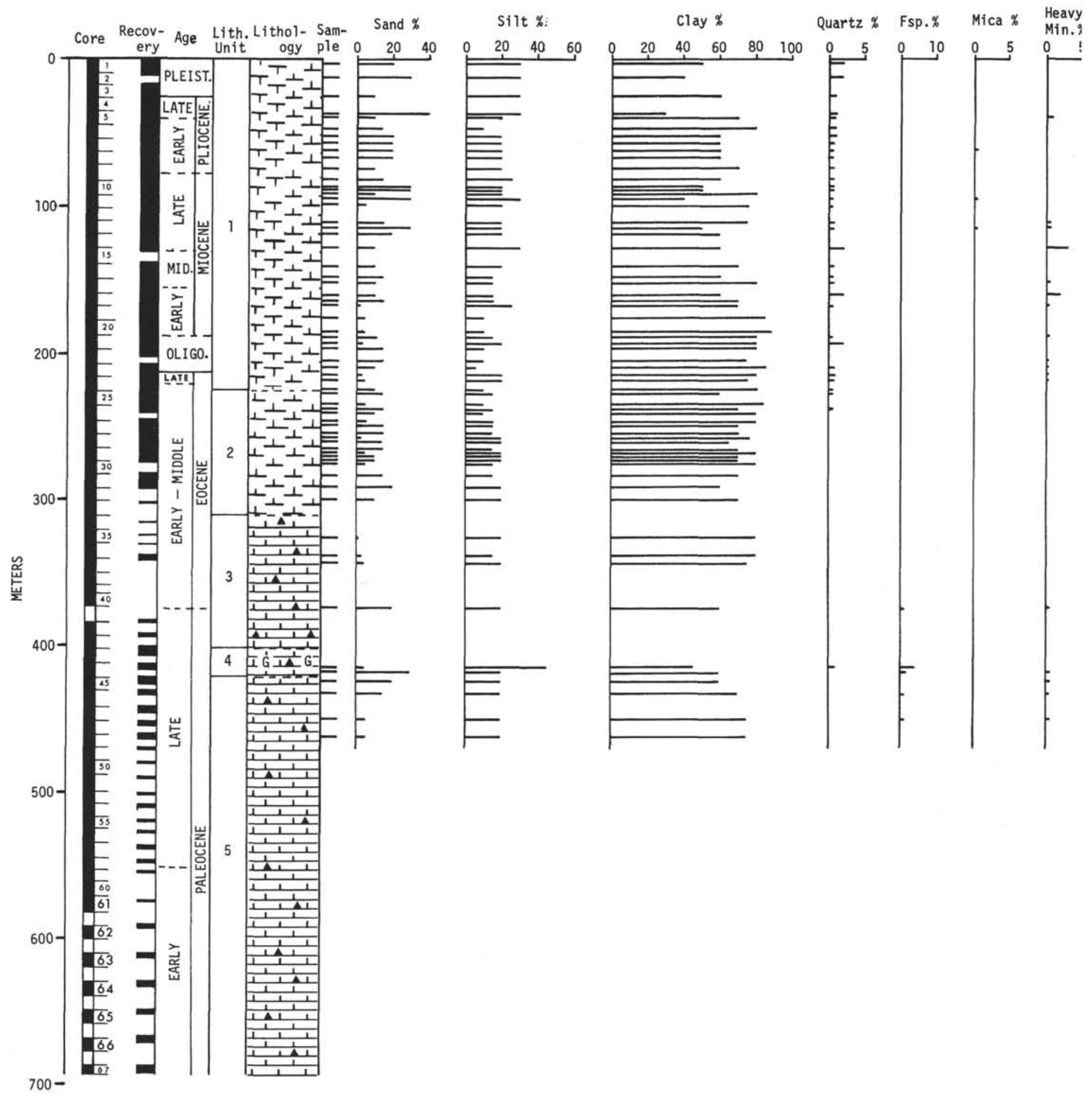




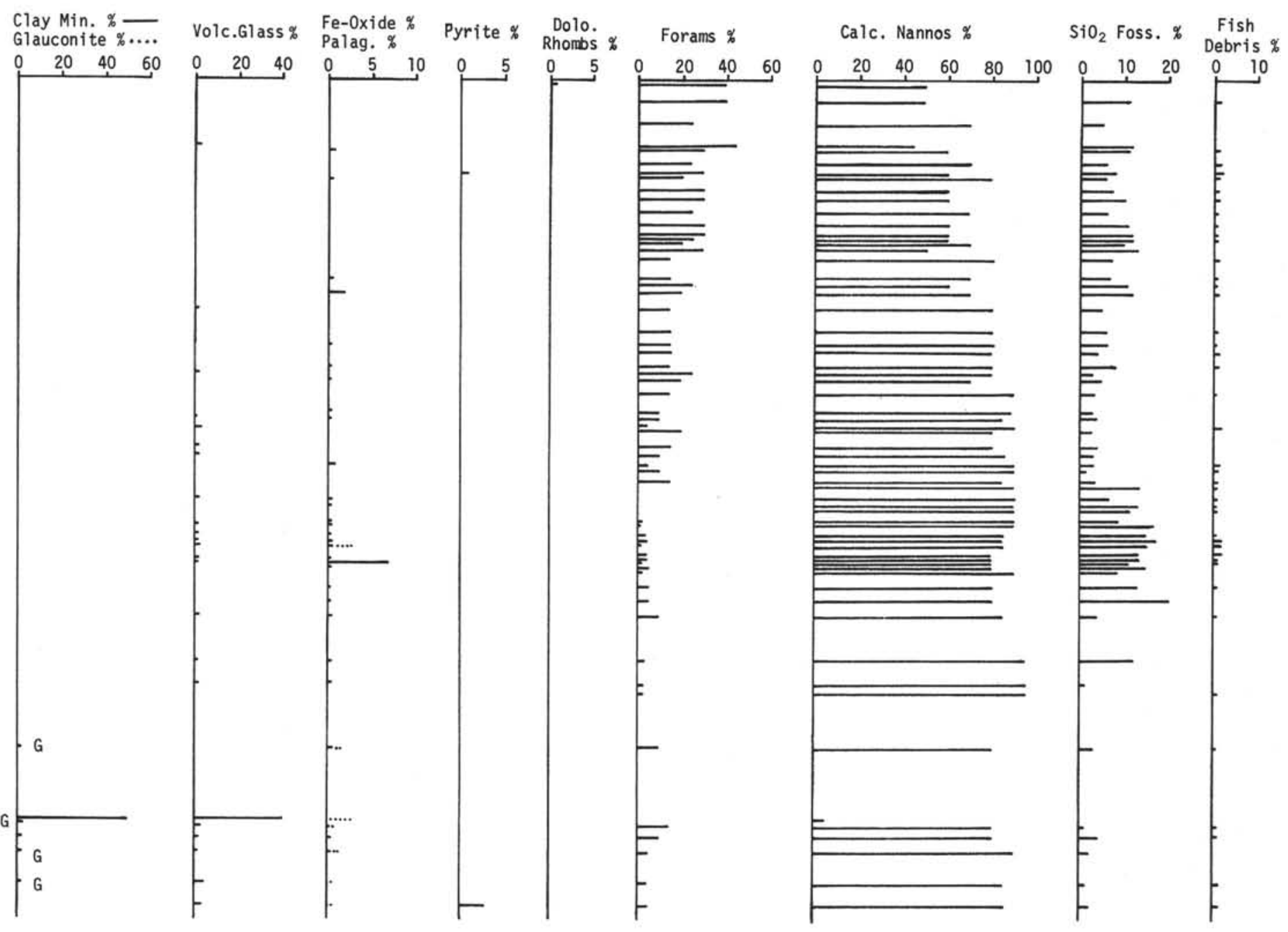



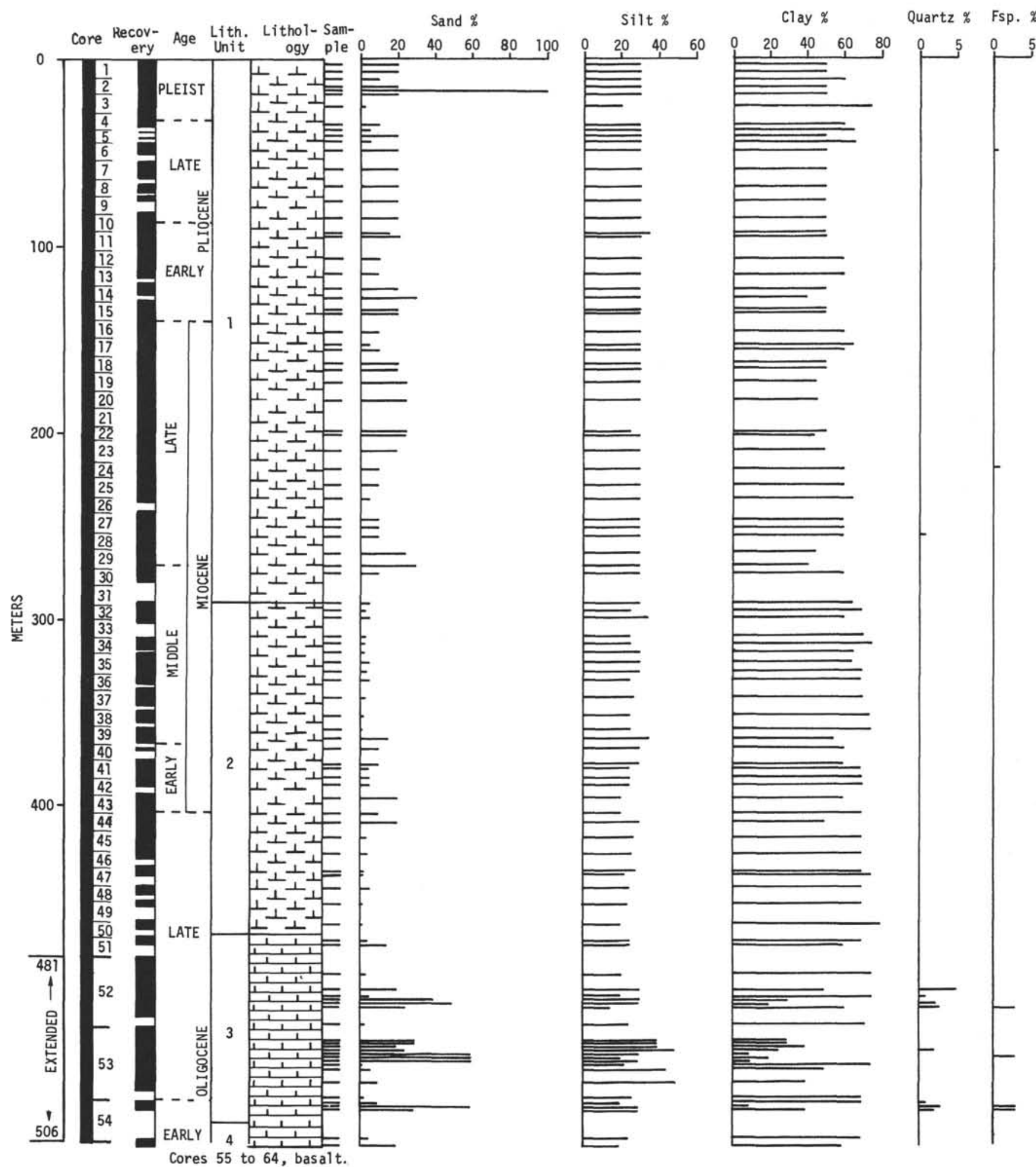


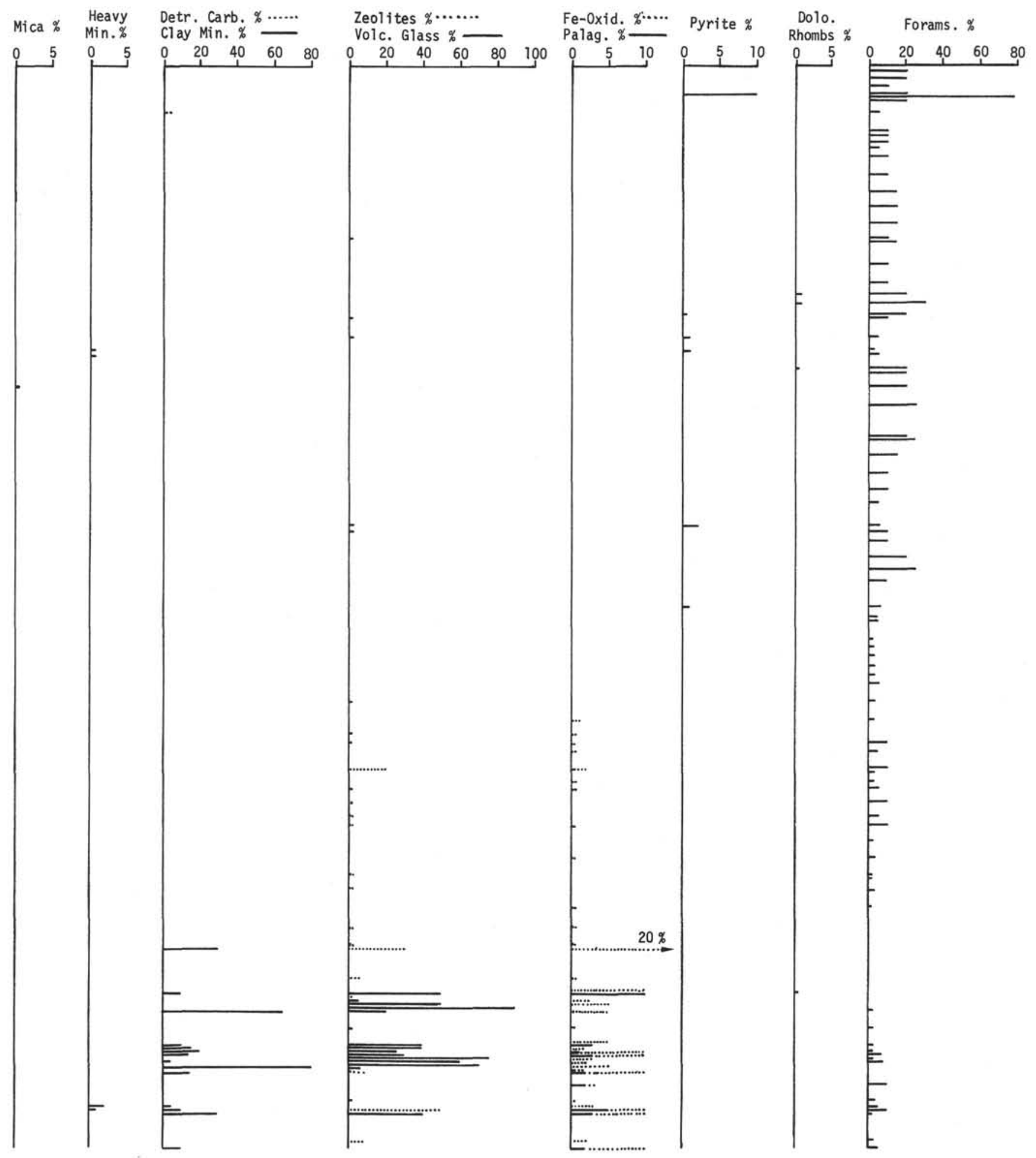




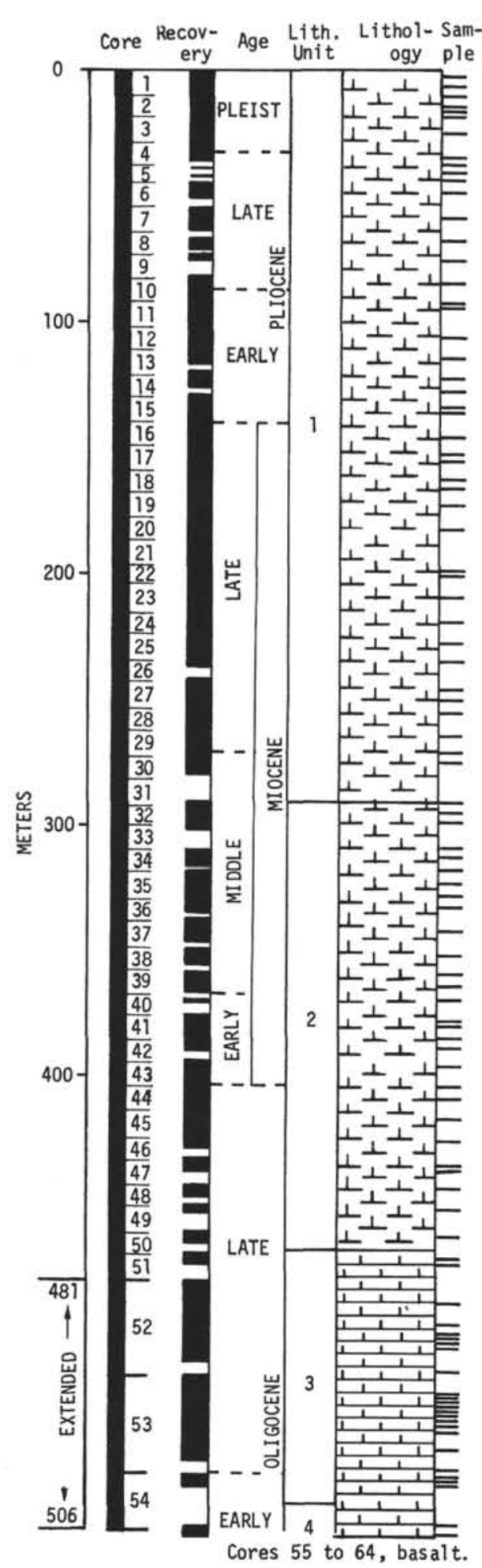

Calc. Nannos $\%-$

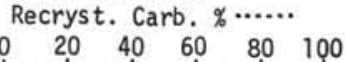

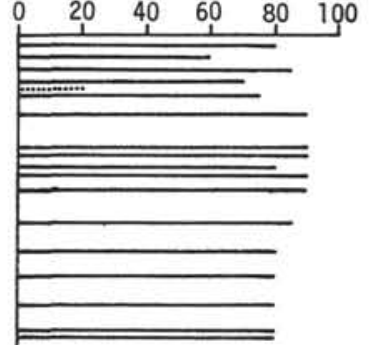

$\mathrm{SiO}_{2}$ Foss. $\%$

Fish

$\begin{array}{llllll}0 & 10 & 20 & 0 & 10 & 20\end{array}$
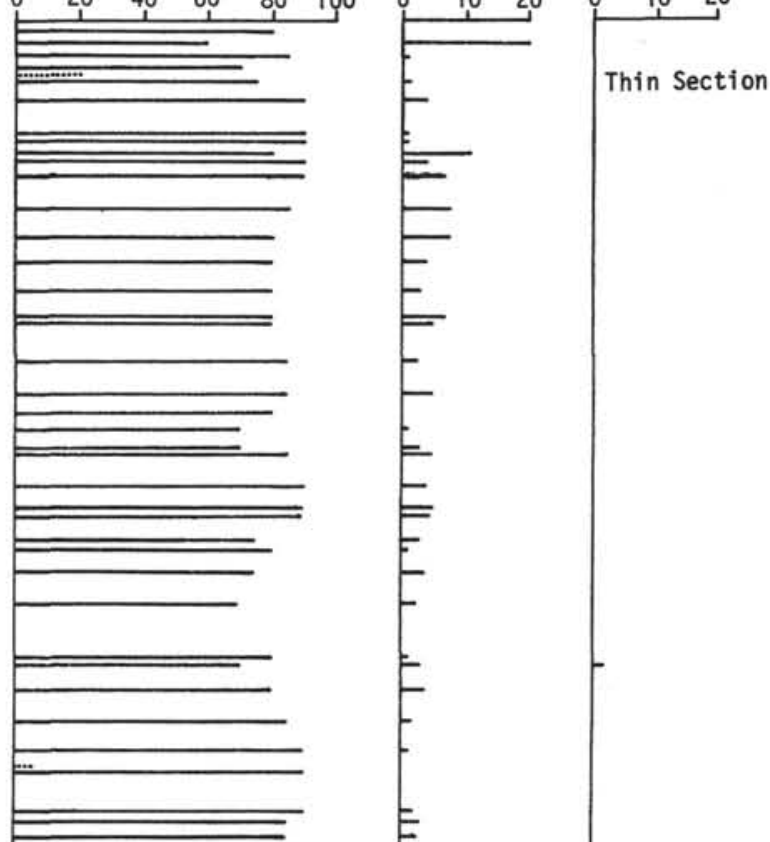

$E$
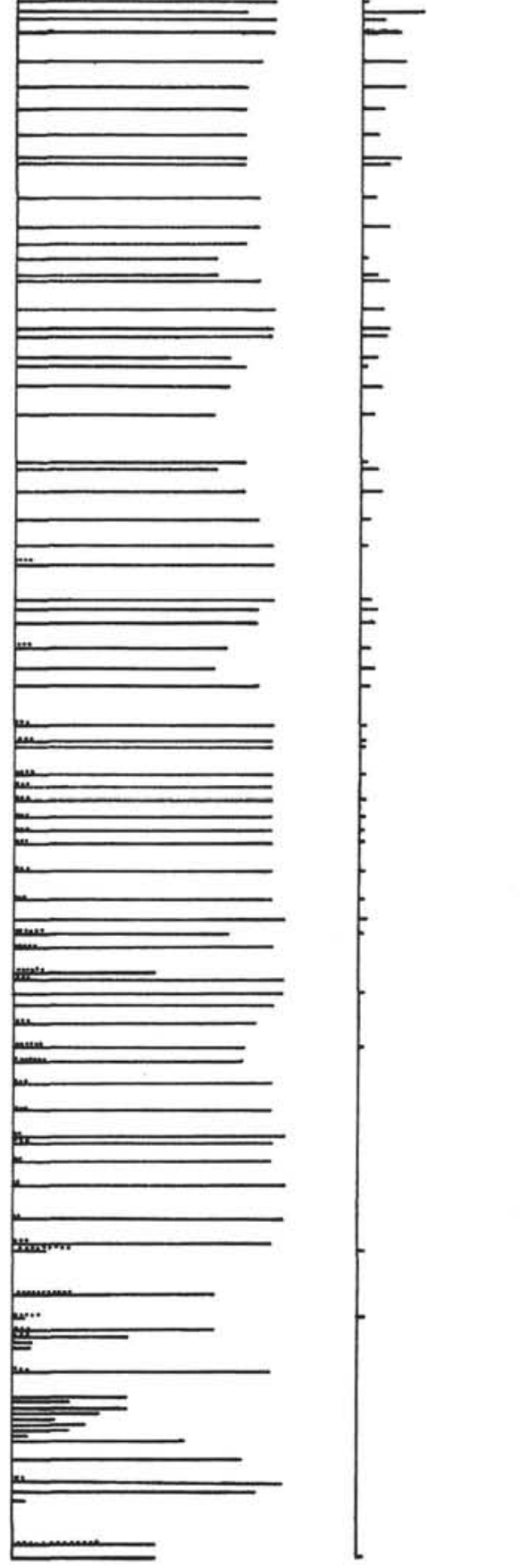

Thin Section 